M I C H A E L C.B U R D A

Humboldt-Universität zu Berlin

\author{
JEN N IFER HUNT
}

University of Montreal

\title{
From Reunification to Economic Integration: Productivity and the Labor Market in Eastern Germany
}

IT IS DIFFICULT TO FIND A MORE dramatic episode of economic dislocation in peacetime during the twentieth century than that associated with the reunification of Germany. It is a sad irony of history that the plucky East Germans who toppled the dictatorship of the proletariat in the bloodless revolution of 1989 were rewarded with an economic bloodletting on such a vast scale. From 1989 to 1992, GDP in the former German Democratic Republic declined by roughly 30 percent, value added in industry by more than 60 percent, and employment by 35 percent. During the same period, unemployment rose from officially zero to more than 15 percent. That figure, moreover, is based on registered unemployment only; joblessness

For excellent research assistance we thank Silke Anger, Almut Balleer, Anja Schneider, and Nils Schulze-Halberg, as well as Bianca Brandenburg, Anja Heinze, and Tom Krüger. We received helpful comments from Patricia Anderson, Antonio Ciccone, Helmut Seitz, Harald Uhlig, Holger Wolf, Janet Yellen, and participants at the Brookings Papers conference. We received valuable data from Martin Rosenfeld, Rupert Kawka, Harald Kroll, and Udo Ludwig (all at the Institut für Wirtschaftsforschung, Halle), from Bernd Seidel, Dieter Vesper, and Erika Schulz (all at the Deutsches Institut für Wirtschaftsforschung), from Steffen Maretzke (Bundesamt für Bauwesen und Raumordnung), from the state statistical offices of Saxony and Mecklenburg-Vorpommern, from the Federal Statistical Office (Statistisches Bundesamt), and from Irwin Collier. This research was supported by the Deutsche Forschungsgemeinschaft (Project BU 921/1-1, "Transfers im Gefolge der deutschen Wiedervereinigung"; Sonderforschungsbereich 373, Quantifikation und Simulation wirtschaftlicher Prozesse) and was performed while Jennifer Hunt was at Yale University. 
rose to 33 percent if hidden unemployment (early retirement, involuntary part-time work, makework, training schemes for the unemployed, and so on) is included.

Ten years after East Germany came in from the cold, the success of the transition from socialism cannot easily be summarized. By 2000, GDP per capita in the eastern states (Länder) of the reunited Germany including Berlin had risen to 65.3 percent of that in the western states (if Berlin is excluded, the figure is 60.6 percent). That is an impressive accomplishment by the yardstick of economists' more pessimistic forecasts a decade ago. Thanks to generous transfers from the west, consumption per capita has converged even more. Miriam Beblo, Irwin Collier, and Thomas Knaus report that 81 percent of easterners have seen their incomes rise during the transition. ${ }^{1}$ However, convergence in productivity has slowed sharply, implying the need for continuing transfers, and the labor market has yet to recover from the initial shock. Even the unemployment rate cannot easily be summarized, since, again, it depends on whether people in makework and training programs are included. The eastern unemployment rate based on registered unemployed was 18.8 percent in 2000, more than twice the rate in the west; it was 27 percent in 1997 if hidden unemployment is included. Measures based on survey data, taking search and availability into account, show that the unemployment rate averaged 13 percent from 1994 to 1999. The employed share of the eastern working-age population (those aged eighteen to sixty-five) declined from 83 percent in 1990 to 65.2 percent in 1999 , compared with a steady 73 percent in the west over the same period.

German reunification is paradigmatic of the economic integration of any two neighboring regions at different levels of economic development. The mixed success of the transition shows the difficulty of development even under the most auspicious circumstances. The former East Germany was immediately able to import sound institutions, including political, legal, monetary, banking, and industrial relations systems, from its more developed partner. At a minimum, these have enabled eastern Germany to avoid the anarchic equilibrium in which Russia finds itself today. Furthermore, eastern Germany has benefited from the largesse, labor market, and expertise of a rich neighbor sharing a culture and language. Its experience serves as a crucible for understanding the ramifications of other,

1. Beblo, Collier, and Knaus (2001). 
larger-scale regional integration projects. The milestone achievement of German monetary, economic, and social union now stands as a benchmark (and perhaps as a foil) not only for the economic integration of the rest of central and eastern Europe with the European Union, but also for the immediate consequences of European Monetary Union.

Although the eastern German transition has attracted the continuous attention of economists, the issues have changed. The one-for-one conversion of East German ostmarks for deutsche marks, the privatization and restructuring of state enterprises, and the striking initial jump in real wages are no longer matters of policy debate, although they may have left their mark on the economy. We take the position that the ultimate measure of the economic success of German reunification is no longer the introduction of a market economy, but rather the attainment of an efficient production pattern made possible by the union of the two regions. This must be accomplished by growth in eastern GDP per capita, which is by definition the sum of growth in labor productivity and the employment rate. For this reason, the analysis of this paper focuses on two issues: the first is the dramatic slowdown in productivity growth in eastern Germany since the early 1990s, and the second is the dysfunctional nature of its labor market-why unemployment, or more precisely the underutilization of labor, is so high.

Our original analysis has three core components. We construct measures of capital stocks in each of the eastern German states and proceed to estimate total factor productivity (TFP) in both eastern and western states. We then use microeconometric evidence to assess the sources of poor employment and unemployment performance in the east. Finally, we assess the mobility of labor in an empirical study of migration patterns in unified Germany.

These components fit into our two-pronged inquiry as follows. We identify TFP, rather than the quantity or the quality of inputs, as the key to understanding the slowdown in convergence in output per worker. From available microdata we observe that the east-west productivity gap is now constant across skill levels, leading us to speculate that poor infrastructure and lack of business skills in the east, rather than lack of capital, explain the gap. We then seek the inefficiencies behind the low employment rate, which is associated with a smaller capital stock and lower output than would be consistent with full convergence. The wage structure is surprisingly similar in east and west, suggesting that the breakdown 
in the industrial relations system adopted upon reunification is allowing more flexibility in the labor market. We believe, however, that wages in the east are still too high. Our analysis of migration flows within Germany suggests that high wages have kept easterners at home, despite the related rise in unemployment. We conclude with policy recommendations. ${ }^{2}$

\section{German Reunification a Decade Later}

The Berlin Wall was irrevocably breached on November 9, 1989. ${ }^{3}$ In March 1990 the first free elections in East Germany since 1932 brought to power a conservative, market-friendly government allied with thenChancellor Helmut Kohl. The election of a government favoring rapid reunification reduced uncertainty about the future, and the economic, social, and monetary union of July 1, 1990, ushered in the key economic changes. The decision to exchange ostmarks for deutsche marks at a rate of one for one was a source of controversy. Political unification occurred on October 3, 1990, bringing the eastern states of Berlin, Brandenburg, Mecklenburg-Western Pomerania, Saxony, Saxony-Anhalt, and Thuringia into the Federal Republic of Germany. ${ }^{4}$

Already by the spring of 1990 it had become evident that the East German economy was in shambles, belying even the most pessimistic esti-

2. Statistics in this introduction are from the Deutsches Institut für Wirtschaftsforschung, or DIW (Vierteljährliche Volkswirtschaftliche Gesamtrechnung des DIW, various years) and are somewhat more conservative than those reported by the Federal Statistical Office (Statistisches Bundesamt). The employment and unemployment statistics are from the Federal Employment Office (Bundesanstalt für Arbeit) and the Sachverständigenrat zur Begutachtung der gesamtwirtschaftlichen Entwicklung. The unemployment numbers based on International Labour Organisation concepts come from the German Socio-Economic Panel (GSOEP), described later in the paper.

3. As the facts related here are now a matter of economic history, we refer the reader to the now-classic "zero hour" analyses for more details: Akerlof and others (1991), Sinn and Sinn (1991), Collier and Siebert (1991), and Siebert (1992).

4. We include Berlin as an eastern state because reunification has stripped this metropolis, with a population roughly three times that of the next largest German city, of the primacy that usually characterizes large metropolitan areas in advanced economies. Whereas Hamburg, western Germany's largest city, boasted a GDP per capita of 170 percent of the national average in 2000, Berlin's was only 91 percent. 
mates of the Central Intelligence Agency and other U.S. intelligence sources. Economic and monetary union meant instant trade integration: not only could curious easterners visit the west, but they could buy goods from enterprising western German traders. Domestic demand and foreign demand from other former communist countries slumped. Industrial production in the east fell by two-thirds within eighteen months of the Wall's opening, ${ }^{5}$ even though much unprofitable production was propped up by a combination of subsidies to involuntary part-time employment and to money-losing enterprises. Unemployment rose quickly. Those who kept their jobs benefited from rapid wage increases bargained by the western German labor unions. Others obtained large wage increases simply by moving to the west: more than 1 million people (6 percent of the eastern population) did so in the period 1989-91.

The collapse of the labor market was cushioned by the introduction of the western social welfare system and by active labor market programs (training programs and the like). The 18-percentage-point difference, cited in the introduction, between the unemployment rate and the underemployment rate in 1992 shows the initial impact of these measures. ${ }^{6}$ State enterprises meanwhile were taken over by the Treuhandanstalt, a public trust set up to manage, hold, and ultimately dispose of state property in the east. Privatization was rapid by transition standards. ${ }^{7}$ The Treuhandanstalt had wound down officially by 1995 and been replaced by a much slimmer version with a fatter name, the Bundesanstalt für vereinigungsbedingte Sonderaufgaben, whose primary task was to control and enforce the thousands of contracts under which the assets of central planning had been privatized, as well as to sell off the last dregs of East German industry and real estate.

Table 1 summarizes three of the usual "headline" economic indicators-GDP growth, unemployment, and nonemployment-for eastern Germany since reunification. From 1992 through 1994 eastern GDP growth was impressive, despite the loss of population. Its fascination for monetary economists notwithstanding, the currency conversion resulted merely in a blip in the growth trend of broad money (M3), and subsequent

5. Siebert (1992).

6. As early retirees gradually entered the normal retirement programs, the difference between the unemployment and underemployment rates fell to 7.5 percentage points in 1998.

7. Roland (2000) argues that it was indeed too fast. 
Table 1. Real GDP Growth, Unemployment, and Nonemployment in Eastern and Western Germany, 1990-2000

Percent

\begin{tabular}{|c|c|c|c|c|c|c|c|}
\hline \multirow[b]{3}{*}{ Year } & \multirow{2}{*}{\multicolumn{2}{|c|}{$G D P^{\mathrm{b}}$}} & \multicolumn{3}{|c|}{ Unemployment } & \multirow{2}{*}{\multicolumn{2}{|c|}{$\begin{array}{c}\text { Non- } \\
\text { employment }^{\mathrm{d}}\end{array}$}} \\
\hline & & & \multirow[b]{2}{*}{ East } & \multirow[b]{2}{*}{ West } & \multirow{2}{*}{$\begin{array}{c}\text { West } \\
(B L S)^{\mathrm{c}}\end{array}$} & & \\
\hline & East & West & & & & East & West \\
\hline 1990 & -15.6 & 5.7 & n.a. & n.a. & 5.0 & n.a. & n.a. \\
\hline 1991 & -22.7 & 4.6 & 10.3 & 6.3 & 4.3 & 26.8 & 27.1 \\
\hline 1992 & 7.3 & 1.5 & 14.8 & 6.6 & 4.6 & 34.0 & 27.1 \\
\hline 1993 & 8.7 & -2.6 & 15.8 & 8.2 & 5.7 & 35.1 & 27.9 \\
\hline 1994 & 8.1 & 1.4 & 16.0 & 9.2 & 6.5 & 34.1 & 28.5 \\
\hline 1995 & 3.5 & 1.4 & 14.9 & 9.3 & 6.5 & 33.4 & 28.7 \\
\hline 1996 & 1.7 & 0.6 & 16.7 & 10.1 & 7.2 & 34.2 & 29.0 \\
\hline 1997 & 0.3 & 1.6 & 19.5 & 11.0 & 7.8 & 35.0 & 28.5 \\
\hline 1998 & 0.6 & 2.3 & 19.5 & 10.5 & 7.5 & 35.2 & 27.9 \\
\hline 1999 & 1.0 & 1.6 & 19.0 & 9.9 & n.a. & 34.8 & 26.9 \\
\hline 2000 & 1.1 & 3.3 & n.a. & n.a. & n.a. & n.a. & n.a. \\
\hline
\end{tabular}

Sources: Deutsches Institut für Wirtschaftsforschung (DIW), German Federal Statistical Office, U.S. Bureau of Labor Statistics, and Sachverständigenrat zur Begutachtung der gesamtwirtschaftlichen Entwicklung.

a. Berlin is included with eastern Germany for GDP measures after 1990, but split into east and west for the unemployment measures.

b. Measured at market prices (including subsidies and net interest) using the European System of National Accounts in 1995 prices (after 1990) and the German national income and product accounts (for 1990).

c. Measured according to the U.S. Bureau of Labor Statistics' concept of unemployment.

d. Defined as 100 minus the employed share of the working-age population.

corrective action by the Bundesbank ensured that German reunification would go down in history as a nonmonetary event. Growth slowed after 1994, however, and then fell below the western German level in 1997. The rise of the eastern unemployment rate based on registered unemployed to almost 20 percent has already been mentioned. The western unemployment rate on the same measure peaked at 11 percent in 1997 , but this rate is known to overstate unemployment, as is shown by the column in table 1 reporting U.S. Bureau of Labor Statistics estimates of western unemployment according to U.S. concepts (this series has since been discontinued). ${ }^{8}$ The sharp rise in nonemployment in the east was accompanied by declining participation rates: from 1991 to 2000 labor force participation for eastern males fell from 86 percent to 79.8 percent, and that for females from 77.2 percent to 72.2 percent (compared with overall constancy in the west).

8. The western unemployment rate based on the GSOEP survey (not reported here) is lower than the U.S. Bureau of Labor Statistics estimate by about 2 percentage points; thus the eastern rate cited in the introduction may be similarly underestimated. 
Table 2 indicates how Germany's central European neighbors have fared on similar indicators. All the countries considered suffered a sharp initial output fall, which Gérard Roland believes was precipitated by price liberalization. ${ }^{9}$ But eastern Germany's initial output fall and its employment fall were both more severe than those of its neighbors. ${ }^{10}$

\section{How Much Convergence Has Occurred?}

The meteoric recovery of West Germany from the ashes of World War II inspired many commentators to expect the same from the eastern states after 1990. An important difference, however, is that whereas the postwar West German capital stock survived the war largely intact, post-Wall eastern Germany had to start from scratch. Nevertheless, many saw the initial growth spurt, evident in table 1, as a harbinger of convergence within a decade. ${ }^{11}$ At the gloomier end of the spectrum, Robert Barro and Xavier Sala-i-Martin invoked the prediction of the Solow growth model around the steady state, as well as empirical observation of the United States, Europe, and Japan, to argue that GDP growth closes at most only 2 percent a year of any gap in GDP per capita over long periods, conditioning on the usual variables. ${ }^{12}$ This implied that convergence would require two or more generations.

CONVERGENCE IN CONSUMPTION. One of the most important measures of the success of transition must be living standards, proxied in the data by aggregate consumption expenditure in the national income accounts. Unfortunately, the Federal Statistical Office stopped reporting disaggregated expenditure by region after 1995 , in a move that appears politically

9. Roland (2000).

10. The Czech experience is informative because of the real economic similarities with the former East Germany at the outset of the transformation (Burda, 1991). Even before the "velvet divorce" of the Czech and Slovak Republics in 1991, the Czechoslovak currency (the koruna) had been devalued sharply; its fall was celebrated at the time as a clever demand management strategy. But although a cheap koruna helped exporters and kept unemployment low for some time, it also led firms to postpone restructuring and contributed to a sharp deterioration in banks' loan portfolios, culminating in a crisis in 1996-97.

11. See the extensive discussion in Giersch, Paqué, and Schmieding (1992) and Dornbusch and Wolf (1992).

12. Robert Barro, "Eastern Germany's Long Haul," Wall Street Journal, May 3, 1991, p. A10, and "Why Eastern Germany Still Lags," Wall Street Journal, June 11, 1998, p. A22; see also Barro and Sala-i-Martin (1991, 1992, 1995). 


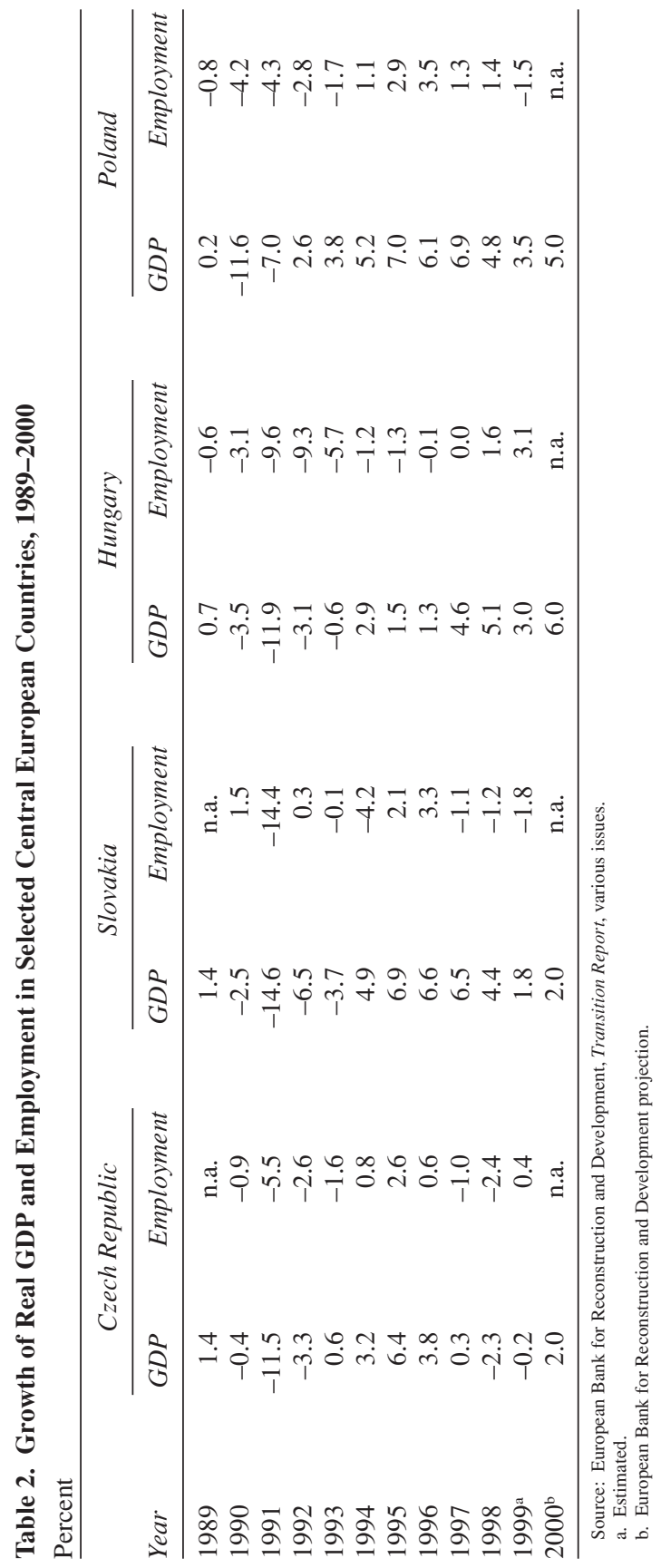


motivated; the only data available since then are indirect estimates generated by research institutes and state statistical offices. The first column of table 3 reports some estimates by Ulrich Blum and Simone Scharfe and documents the great strides that have been made, especially when the initial conditions are considered. ${ }^{13}$ On top of that, infrastructure in eastern Germany was modernized to the tune of more than DM 140 billion during 1992-98; this amounted to a third of all infrastructure spending in all of Germany over that period, raising it to western German levels in many consumption-related categories. ${ }^{14}$ Table 4 documents the same point at the microeconomic level, also showing the striking similarities in household behavior in the two regions after an initial adjustment period..$^{15}$

CONVERGENCE IN WAGES. A highly visible consequence of the integration of the two Germanys' labor markets was an unprecedented rise in both nominal and real wages in the east. The second column of table 3 gives details for the period 1991-2000 for gross weekly nominal wages. At the time of monetary union, earnings in East Germany were about a third of those in West Germany, given the one-for-one exchange rate, having already risen by severalfold in ostmark terms up to June $1990 .{ }^{16}$ By 1996 eastern wages had reached three-quarters of western levels. (Since then they have not increased in relative terms and indeed have actually fallen a bit since 1997.) This increase was not observed in any of the other transition economies, even in the Czech Republic, whose initial conditions were quite similar to those in East Germany. ${ }^{17}$

CONVERGENCE IN PRODUCTIVITY. The last two columns of table 3 document the development of productive economic activity, that is, the extent to which the eastern German region can generate value added at world market prices. The first indicator, labor productivity, grew rapidly throughout the period from less than 45 percent of the western level in 1991 to 73 percent in 2000. In many sectors and establishments, eastern German productivity now exceeds that in the west, a result of having the newest

13. Blum and Scharfe (2001).

14. See Vesper (2001). An excellent example is the telephone system, which before 1990 was characterized by rotary dialing, poor connections, unavailability of service, and unwanted third-party crosstalk. Today, in contrast, eastern Germany's ISDN and fiber optic networks are the envy of most of Europe.

15. This finding has been recently confirmed with detailed expenditure data by Grunert (2000).

16. See Sinn and Sinn (1991, p. 147) and the references cited therein.

17. Burda (1991). 
Table 3. Measures of Eastern German Convergence, 1991-2000

Percent of corresponding western German measure

\begin{tabular}{ccccc}
\hline Year & $\begin{array}{c}\text { Consumption } \\
\text { per capita }^{\text {a }}\end{array}$ & $\begin{array}{c}\text { Gross weekly } \\
\text { nominal wage }^{\mathrm{b}}\end{array}$ & $\begin{array}{c}\text { Labor } \\
\text { productivity }^{\mathrm{c}}\end{array}$ & $\begin{array}{c}\text { GDP } \\
\text { per capita }^{\mathrm{d}}\end{array}$ \\
\hline 1991 & 43 & 50 & 44 & 42 \\
1992 & 54 & 65 & 57 & 50 \\
1993 & 65 & 71 & 67 & 59 \\
1994 & 70 & 72 & 70 & 64 \\
1995 & 73 & 74 & 71 & 66 \\
1996 & 72 & 72 & 72 & 67 \\
1997 & 73 & 76 & 72 & 67 \\
1998 & 73 & 76 & 72 & 66 \\
1999 & n.a. & 76 & 72 & 66 \\
2000 & n.a. & 73 & 73 & 65 \\
\hline
\end{tabular}

Sources: Blum and Scharfe (2001), German Federal Statistical Office, and Arbeitskreis Volkswirtschaftliche Gesamtrechnungen der Länder (AKVGRL, 2001).

a. Uses average of successive year-end population values. Berlin is included with western Germany.

b. East Berlin is included with eastern Germany and West Berlin with western Germany.

c. Total value added at 1995 prices per employed person. Berlin is included with eastern Germany.

d. Total value added at 1995 prices per person. Berlin is included with eastern Germany.

Table 4. Household Ownership of Selected Consumer Goods in Eastern and Western Germany, 1991 and 1998 $^{\mathrm{a}}$

Percent of households ${ }^{\mathrm{b}}$

\begin{tabular}{lccc}
\hline Item & East, 1991 & East, 1998 & West, 1998 \\
\hline Automobile & 93.8 & 98.0 & 96.0 \\
CD player & 2.2 & 27.5 & 52.6 \\
Color television & 94.9 & 98.6 & 97.3 \\
Dishwasher & 1.1 & 43.6 & 78.5 \\
Home computer & 14.7 & 48.8 & 54.3 \\
Microwave oven & 4.8 & 53.8 & 67.4 \\
Refrigerator & 96.0 & 72.8 & 75.6 \\
Refrigerator-freezer & 5.9 & 35.0 & 32.3 \\
Stereo & 33.3 & 71.1 & 70.4 \\
Telephone & 17.6 & 96.5 & 99.5 \\
VCR & 39.9 & 80.9 & 86.9 \\
Video camera & 3.3 & 37.6 & 39.0 \\
Washing machine & 73.3 & 97.4 & 97.5 \\
\hline
\end{tabular}

Source: Institut der Deutschen Wirtschaft (2000).

a. East Berlin is included with eastern Germany and West Berlin with western Germany.

b. Four-person middle-income households. 
investment and infrastructure available, as will be discussed below. On the other hand, a large part of the increase in productivity simply reflects firms discharging less productive labor and moving up along the marginal product of labor schedule. ${ }^{18}$ The wide disparity in productivity performance in the first years after reunification (documented by Burda and Michael Funke ${ }^{19}$ ) suggests that firms were far from their efficient production frontiers and could achieve some efficiency gain without layoffs. Still, employment reductions as high as 80 to 90 percent at some firms show that labor-intensive production was not in the cards. These unemployed, most of them entitled to generous social benefits, are a major source of massive financial transfers from west to east. As long as there are many unemployed in eastern Germany, the transfer problem and the problem of lagging GDP per capita will continue to haunt the region. The last column of table 3 shows that GDP per capita is below the levels implied by wages, labor productivity, and consumption.

\section{The Cost of German Reunification}

By any measure, German reunification has been an expensive proposition: over the period 1990-2000, total financial transfers from the west -in the sense of a "current account deficit" of the east-exceeded DM 1.5 trillion. The persistent failure of the east to produce enough to carry its own weight means that transfers from the richer west have been and remain necessary. Although such transfers were expected at the outset, their persistence has come as a surprise, raising the specter of eastern Germany becoming a "problem region" like the Appalachians in the United States, Canada's maritime provinces, or the Mezzogiorno in Italy. ${ }^{20}$ The annual net transfer burden remains about $€ 75$ billion a year, or about 5 percent of German GDP. The lion's share (about 40 to 45 percent) represents social entitlements, which cannot be cut without fundamentally changing the nature of the German social contract. These transfers result directly from the inherent generosity of the German welfare state and were

18. See Hunt (forthcoming) for a description of this phenomenon for low-wage female workers in 1990-91.

19. Burda and Funke (1995).

20. For an analysis of the Mezzogiorno issue, see Hughes-Hallet and Ma (1993). 
triggered automatically by conditions following reunification. ${ }^{21}$ The risk of further transfers and dependency still exists. ${ }^{22}$

It should be emphasized, however, that these transfers, both public and private, have not gone merely to support eastern German consumption. East Germany was a threadbare economy in 1989, using obsolete technologies and machines that were past their productive prime. A number of posthumous analyses have argued that its collapse was accelerated by misguided investment policies starting in the 1970s. ${ }^{23}$ Early back-of-theenvelope calculations forecast a need of roughly $\$ 50$ billion to $\$ 100$ billion a year to rebuild the capital stock, ${ }^{24}$ and these estimates have been validated.

Table 5 documents the remarkable extent to which eastern Germany has accumulated physical capital: since 1990, easterners have installed more than half a trillion marks worth of equipment, and more than twice that amount in structures. Taken together, this is roughly DM 100,000 for every inhabitant of the region. It is thus incorrect to claim that the region's massive "current account deficits" since 1990 have been used solely to finance consumption; in fact, the sum of the transfers roughly equals the cumulative investment undertaken. Like the collapse of production in 1989-92, the intense capital accumulation seen in eastern Germany finds few parallels in modern economic history.

This remarkable achievement is not without its blemishes, however. One salient fact revealed in the table is the lopsided pattern of investment in structures in the east when compared with the west. This is mostly residential housing, but much of it consists of infrastructure and buildings that house productive activity. ${ }^{25}$

\section{Convergence and Integration: A Framework for Analysis}

In what follows we adopt a two-pronged approach to understanding the stall in productivity per capita in the east. Since overall productivity

21. Burda and Busch (forthcoming).

22. In the summer of 2001 the federal and state governments agreed to a new revenuesharing plan, which would guarantee more than DM 300 billion in transfers to the eastern states from 2005 to 2020.

23. Wenzel (1992); Grosser (1998); Ludwig and Stäglin (1999).

24. Burda (1990); Collins and Rodrik (1991); Siebert (1992).

25. Sinn (1995, 2000) and Begg and Portes (2001), among others, have sharply criticized the overly intensive subsidization of construction. 


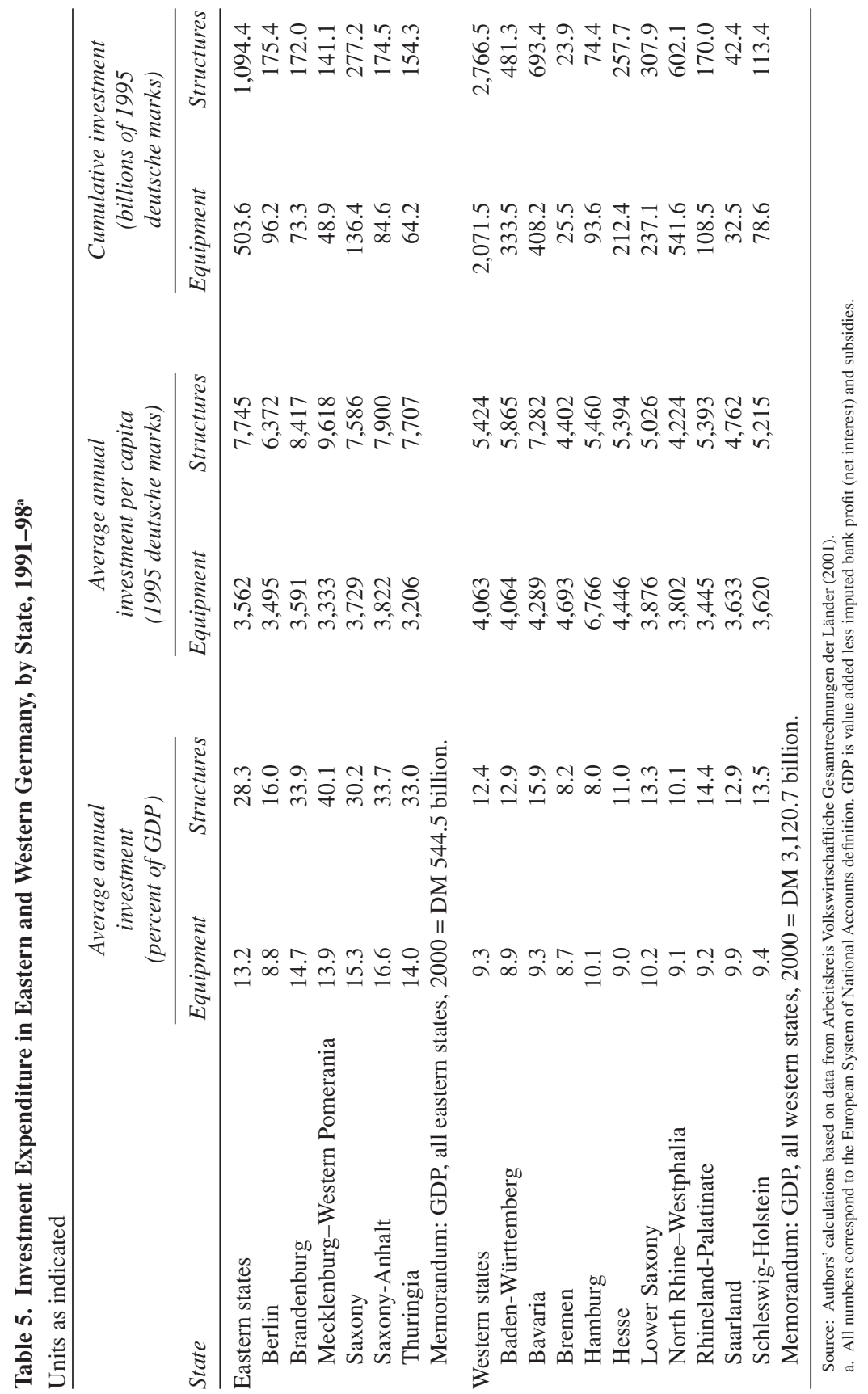


is the product of labor productivity and the employment rate, the first avenue is to investigate why labor productivity remains lower in the east, given the current functioning of the labor market. The second, equally important avenue is to ask why the eastern German labor market fails to put people to work in the same way that its western counterpart does. We thus seek inefficiencies in the labor market, that is, the causes of high unemployment.

At the same time, eastern Germany's stalled productivity per capita must be put into the context of the economic integration of the two regions. Economic integration can be defined as the achievement by two or more geographic regions of the efficient production pattern made possible by their union, using world market prices for output and inputs as the appropriate metric. ${ }^{26}$ Whether these regions are within Germany or across Europe, large gaps in GDP per capita (adjusting for purchasing power) or in factor prices are usually taken as evidence of incomplete integration. Integration may be achieved by any of five mechanisms or their combination: internal accumulation of productive factors such as physical or human capital in the backward regions; labor mobility from capital-poor to capital-rich regions (migration); capital mobility from capital-rich to capital-poor regions (investment); Heckscher-Ohlin trade among regions, which in the absence of complete specialization implies the equalization of factor prices $;{ }^{27}$ and adoption of leading technologies by the backward regions.

Our model of integration stresses the first three mechanisms. ${ }^{28}$ Figure 1 depicts the outset of the integration process between a capital-rich west and a capital-poor east, whose union creates a single small, open economy. For the moment, assume that both regions operate under the same

26. See, for example, Eichengreen (1990).

27. Mundell (1957) stressed the equivalence, under certain conditions, of factor mobility and trade in achieving economic integration. If goods are produced with different factor intensities at common factor prices, and if regions have different relative factor allocations, a region's exports will reflect those differences. In the case of Germany, the east could export those goods that are relatively less intensive in physical capital or relatively more intensive in human capital inputs. However, given the overall capital intensity of production methods in Germany, the similarity of the two regions' human capital endowments, and the high complementarity of human and physical capital, we think that any cone of specialization is likely to be of second-order importance, so that the efficient allocation of capital and labor can be adequately approximated by a diagonal.

28. The model is described in more detail in Burda (2001). 
Figure 1. Possible Integration Paths When Both Regions Have a Common Production Function

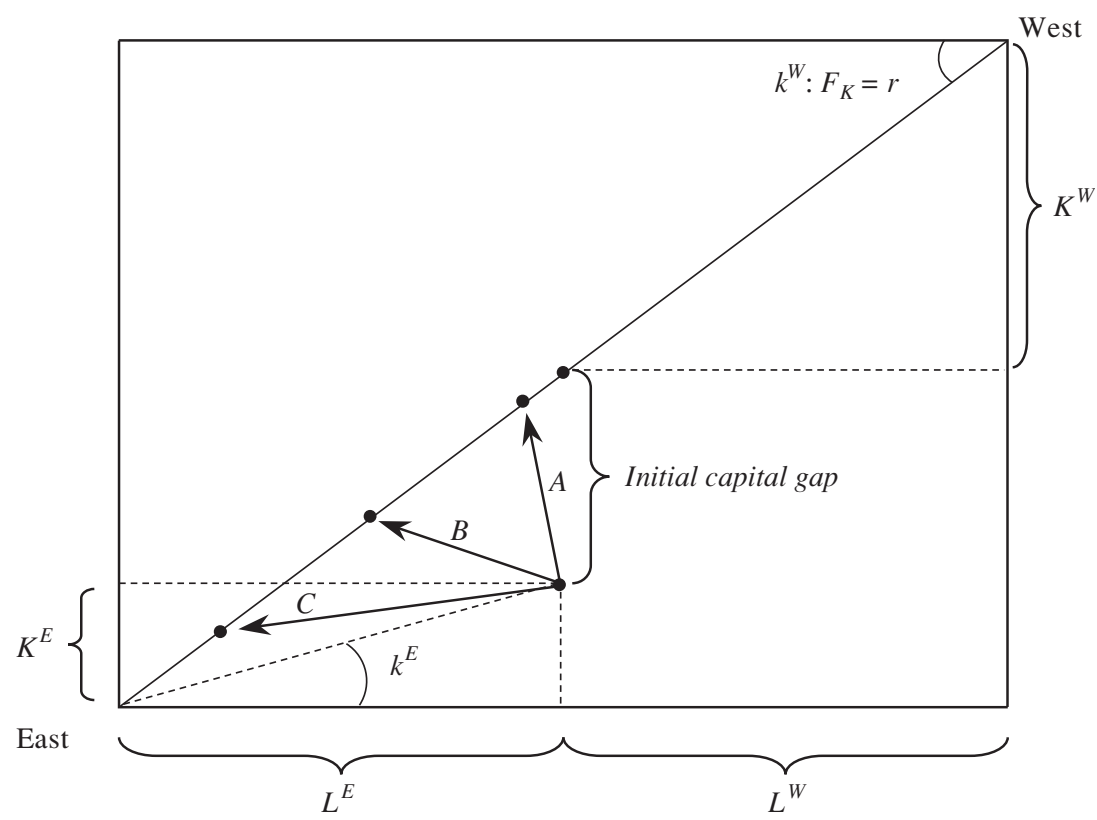

Source: Authors' model as described in the text.

constant-returns production function $F(K, L)$ using capital $(K)$ and labor $(L)$. The economy can borrow and lend freely for projects with positive net present value at the given world interest rate $r$; for simplicity, mobility of labor from the rest of the world is set to zero. As a result, the steady state of the economy in figure 1 lies along the common capital-labor ratio given by the slope of the factor price frontier of the economy at the world interest rate. Integration is represented by various adjustment paths to this diagonal. Path $A$ represents an adjustment process in which capital rapidly locates in the east, but labor moves from east to west slowly; the resulting total size of the eastern economy is not much affected by the integration process. Since the west is assumed to operate at its steady-state capital-labor ratio from the outset, this is equivalent to bringing capital from abroad. In path $B$, in contrast, labor moves rapidly from east to west, but capital moves sluggishly to the east and instead locates mostly in the west. Along path $C$, so little investment occurs in the east that the net 
accumulation of capital there is negative, leading to what some have called the "national park" phenomenon as the east largely empties out.

The assumption of constant returns suggests that there is no unique resting point of the economy; with identical production technologies, any point along the diagonal represents a potential steady state, with no loss of productivity per capita, since both regions are producing at the same capital-labor ratio..$^{29}$ The normative guidelines for selecting the appropriate point in the case of Germany are beyond the scope of this paper; instead, in the rest of this paper we seek simply to examine how TFP, capital accumulation, and labor mobility have characterized German integration.

\section{Assessing Labor Productivity}

Convergence in productivity-one of the key open questions in macroeconomics-remains the central policy question for eastern Germany's economic convergence. In their seminal paper, George Akerlof and his coauthors showed convincingly that productivity in East Germany was much lower than in West Germany when the borders were opened..$^{30}$ Even after a decade of economic integration and remarkable strides, productivity remains lower in the east, as table 3 documented. Yet an analysis by sector reveals that the story is not clear-cut. Table 6 examines sectoral growth in labor productivity over the past decade. ${ }^{31}$ Not only has development been uneven across sectors; it has not been monotonic within all sectors as well. Most striking is the contrast between the gradual rise in the aggregate (a pattern matched in most service sectors) and the patterns observed in agriculture, manufacturing, and construction. Labor productivity in agriculture (including forestry and fishing) quickly reached parity with the west; in manufacturing it has risen slowly since 1995, after sharp initial increases; and in construction it rose sharply at first but has declined since 1996 by 13 to 14 percentage points. The last result mirrors

29. In the event that TFP is permanently higher in one region, the national park outcome will be inevitable, unless subsidies are employed to increase the lower factor returns in the low-TFP region.

30. Akerlof and others (1991).

31. This issue has also been examined in detail by Klodt (2000). The elimination of subsidies to western German-based hard coal mining causes the jump in table 6 from 1995 to 1996. 


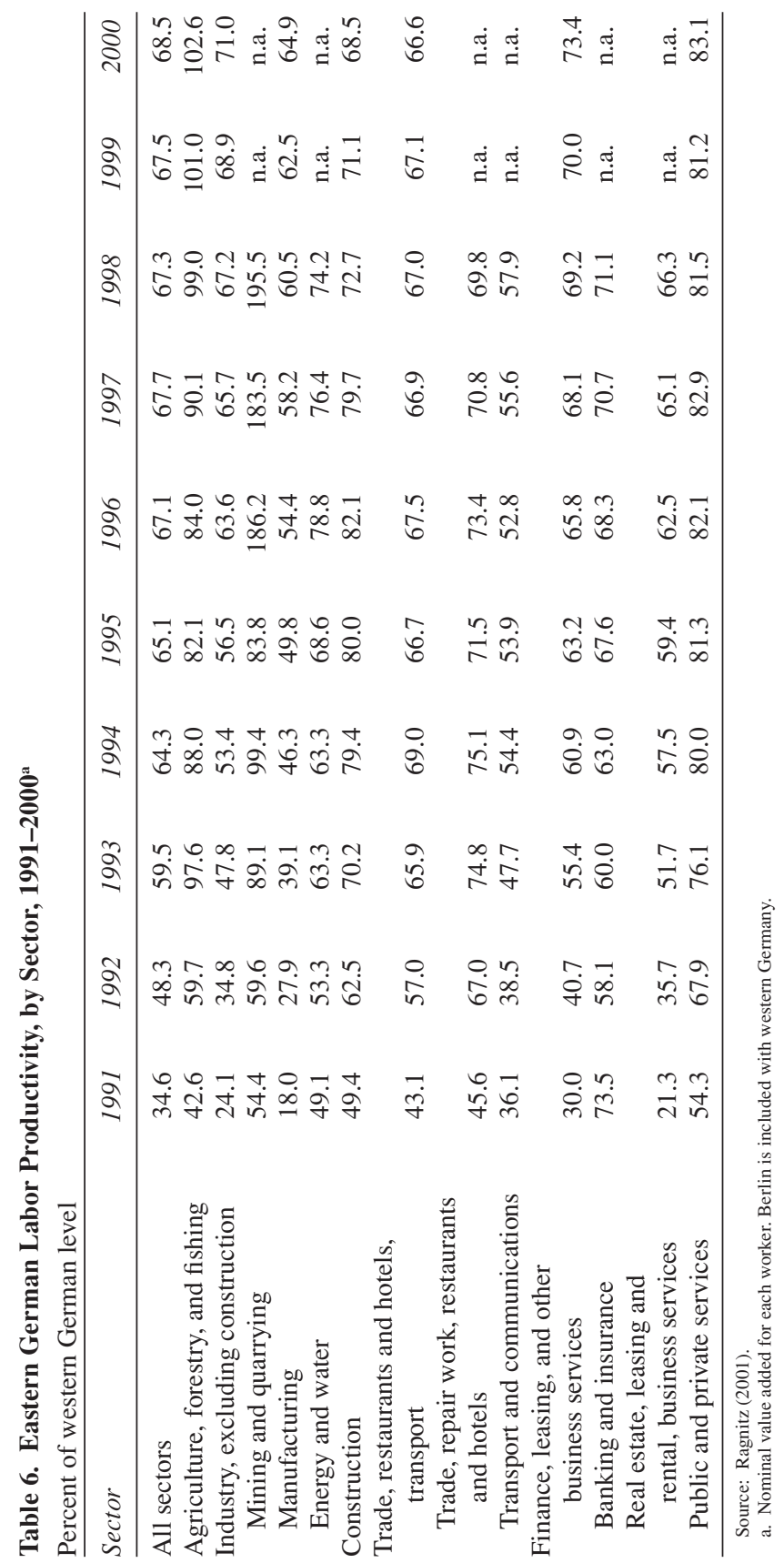


a drop in relative wages and a decline in employment in the construction sector over the period. In short, the decade of the 1990s was not one of stable catch-up.

In this section we attempt to explain labor productivity in Germany from both a microeconometric and a macroeconomic perspective. In addition to analyzing TFP in the German states, we study data from the German Socio-Economic Panel (GSOEP). ${ }^{32}$ The initial western sample was drawn in 1984, whereas the initial eastern sample was taken in June 1990, just before monetary union. We use the sample years 1990-99, primarily as cross sections. The wage measure used is monthly earnings divided by 4.33 times weekly hours. Unless otherwise specified, wages are deflated with separate consumer price indices for east and west and made comparable in purchasing power using results reported by Peter Krause. ${ }^{33}$ The samples of workers include those aged eighteen to fifty-four who are not self-employed, serving an apprenticeship, or employed in agriculture. We exclude older workers since their employment rates are low because of early retirement.

\section{Quantity of Inputs}

PHYSICAL CAPITAL. From the perspective of a neoclassical, constantreturns technology, a gap in labor productivity can result from too little physical capital per unit of labor in the economy. This was certainly the situation in 1990 in East Germany and elsewhere in central and eastern Europe, when the downward revaluation of national capital stocks led to a radical upward revision of the time necessary for convergence. ${ }^{34}$

Any study of the role of private capital in productivity trends should focus on investment expenditure on equipment (as opposed to structures). Equipment capital is known to be the key bottleneck for development, and high rates of investment in equipment are robustly associated with rapid economic growth. ${ }^{35}$ The importance of equipment investment is supported by the fact that individual western German states evidence little or no time-series or cross-sectional variation of equipment capital-to-GDP

32. These data are described in detail in Holst, Lillard, and DiPrete (2001).

33. Krause (1994).

34. See, for example, Collins and Rodrik (1991).

35. DeLong and Summers $(1991,1992)$. 
ratios over the past two decades, whereas the same ratio for structures varies widely across states. The capital-output ratio in the western states, computed using capital stocks estimated by the Federal Statistical Office at 1991 prices, is roughly 0.9 to 1.0 and has been so for two decades. ${ }^{36}$

Low capital-output and capital-labor ratios for equipment imply that rapid catch-up in capital intensity is technically feasible, especially if there is a lot of outside help. To put things in perspective, table 5 showed that cumulative investment in equipment in the period 1991-98 totaled DM 504 billion at 1995 prices; real GDP in the eastern states including Berlin was DM 544 billion in 2000. Assuming an initial equipment stock of zero in the east and an annual depreciation rate of 7.5 percent, the standard accumulation equation already implies a lower bound for the aggregate eastern capital-output ratio of 75 to 90 percent. The actual outcome is more favorable, since some eastern equipment could in fact be used in market activities in 1990. Many eastern enterprises already worked with western capital goods, and foreign investment was already occurring in 1990 and has continued since 1998.

To generate estimates of equipment capital that are comparable with those of other analysts of the eastern German economy, we assume that the capital coefficient (capital-output ratio) in the east had reached the lower range of western levels by 1998 (for details see the appendix). ${ }^{37} \mathrm{We}$ focus on the capital coefficient because both growth theory and empirical observation say it should be stable along a stationary growth path. ${ }^{38}$ Our assumption does not imply that the capital-labor ratio is the same in both east and west, nor does it imply that there is already enough capital around to bring eastern Germany up to western employment rates. It does, however, imply that one can expect only marginal productivity gains

36. These data are based on estimates of capital stocks in the western states by the Federal Statistical Office on the basis of 1991 prices; this series was discontinued in 1998. Other reasons for placing less emphasis on structures include the extensive tax breaks given to construction of residential structures in the east.

37. Our estimates appear to be at least as good as those of other researchers. Our implied estimate of the 1991 equipment capital stock in all of Germany, at 1995 prices, is DM 2.86 trillion. The equivalent at 1991 prices is DM 2.51 trillion. Subtracting the estimate of the DIW at 1991 prices for infrastructural equipment capital yields DM 2.42 trillion, which is only about 3 percent less than Müller's (2001) estimate for the private equipment capital stock (DM 2.50 trillion).

38. Barro and Sala-i-Martin (1995). 
among those currently employed from increasing their endowment of productive equipment. ${ }^{39}$

HUMAN CAPITAL. Eastern workers might also be less productive because they possess less human capital. However, the means of the GSOEP worker samples reported in table 7 show that, in both 1990 and 1999, eastern workers were in fact more educated on average than western workers. ${ }^{40}$ Although a smaller share of easterners than of westerners have degrees from tertiary institutions, a larger share have vocational degrees that typically imply study beyond the usual dual-system apprenticeship, and the proportion with none of these degrees (those who have only "general schooling") is much lower than in the west. The unweighted means reflect oversampling of foreigners residing in the west, but the last observation is true even if only German nationals in the west are considered. (Other variables are little affected by the oversampling.) Although it is not possible to measure actual work experience for the eastern sample, the average for women in particular was much higher in the east in 1990, because female employment rates were higher under communism than in the west. This is reflected in table 7 in the data on average tenure with the current employer in 1990. Burda and Christoph Schmidt show more formally, using a Oaxaca decomposition, that average worker characteristics tended to favor the east in $1990 .{ }^{41}$

\section{Total Factor Productivity}

Eastern workers might also be less productive conditional on input quantities: that is, TFP could be lower in the east. To assess this possibility, we apply the standard Solow decomposition of output growth since 1991 in both the west and the east, using our own estimates of the total equipment capital stock for each state (the appendix provides details). ${ }^{42}$

39. This judgment is shared by Klodt (2000), Ragnitz (2001, p. 182), and Ragnitz, Müller, and Wölfl (2001, pp. 71ff.), all of whom include structures in their capital stock measure.

40. This is confirmed by a number of other observers, including Scheuer (1990), Sinn and Sinn (1991), and Weiss (1991).

41. Burda and Schmidt (1997). In the east, average female tenure overtook average male tenure in the 1990s, probably because males are concentrated in construction and females in the public sector. It is also possible that women include spells of maternity leave in their reported tenure.

42. See Solow (1957), Denison (1967), and Jorgenson, Gollop, and Fraumeni (1987). 


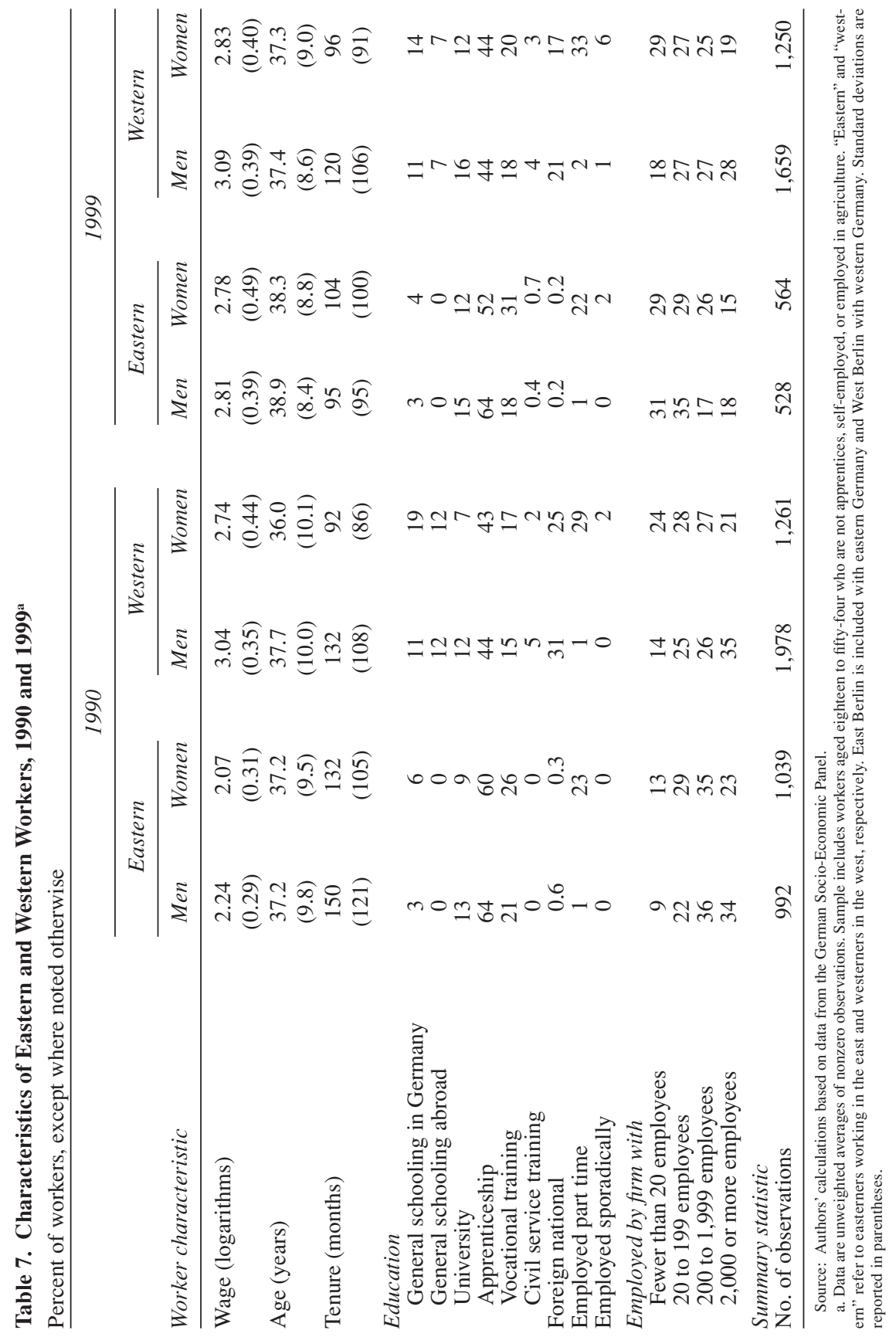


Table 8 presents summary statistics. In addition to the growth attributable to changes in output at constant prices, we report in the first column changes in the terms of trade (the price of each state or region's output relative to the overall German GDP deflator). This addresses the possibility that value added at constant prices neglects an important element of convergence, namely, that a region's output may become more valuable relative to that of other regions..$^{43}$ Finally, we estimate TFP growth (the Solow residual) in each state and region.

The most salient finding is a dramatic slowdown in TFP growth in the east in the latter half of the 1990s. This development is systematic, affecting all states in the same qualitative fashion (although Saxony-Anhalt, a state in which the capital-intensive chemical, machinery, and energy sectors are well represented, exhibits negative TFP growth for almost the entire period). ${ }^{44}$ The Solow decomposition also reveals that although overall factor input growth in the east grew by only 2.4 percent a year over the 1992-95 period, employment's annual contribution fell by 1.8 percent, while that of capital rose by 4.2 percent. Not only was the eastern German isoquant shifting, but a massive move was taking place along that isoquant in the western direction. It is also noteworthy that the west as a whole — and almost all of the individual western German states—remained hardly affected during the postunification decade. The second half of the period saw a return to normal TFP growth in the west. Furthermore, the rapid increase in the relative price of eastern output came to a sudden halt in the second half of the period.

The Solow decomposition for the eastern German economy since 1992 points to deficient TFP growth as the main culprit in slowing convergence. We proceed now to examine possible reasons for the slowdown in TFP growth.

\section{Quality of Inputs}

A first approach to explaining lower TFP in the east is to ask whether the quality of the inputs on which output growth is conditioned is as high as in the west. Although, as documented, the amount of capital is lower

43. This issue is raised by Ragnitz (1999).

44. This finding resembles those of Young (1992) for Singapore, where despite very high investment rates, growth in TFP was not sustainable. 


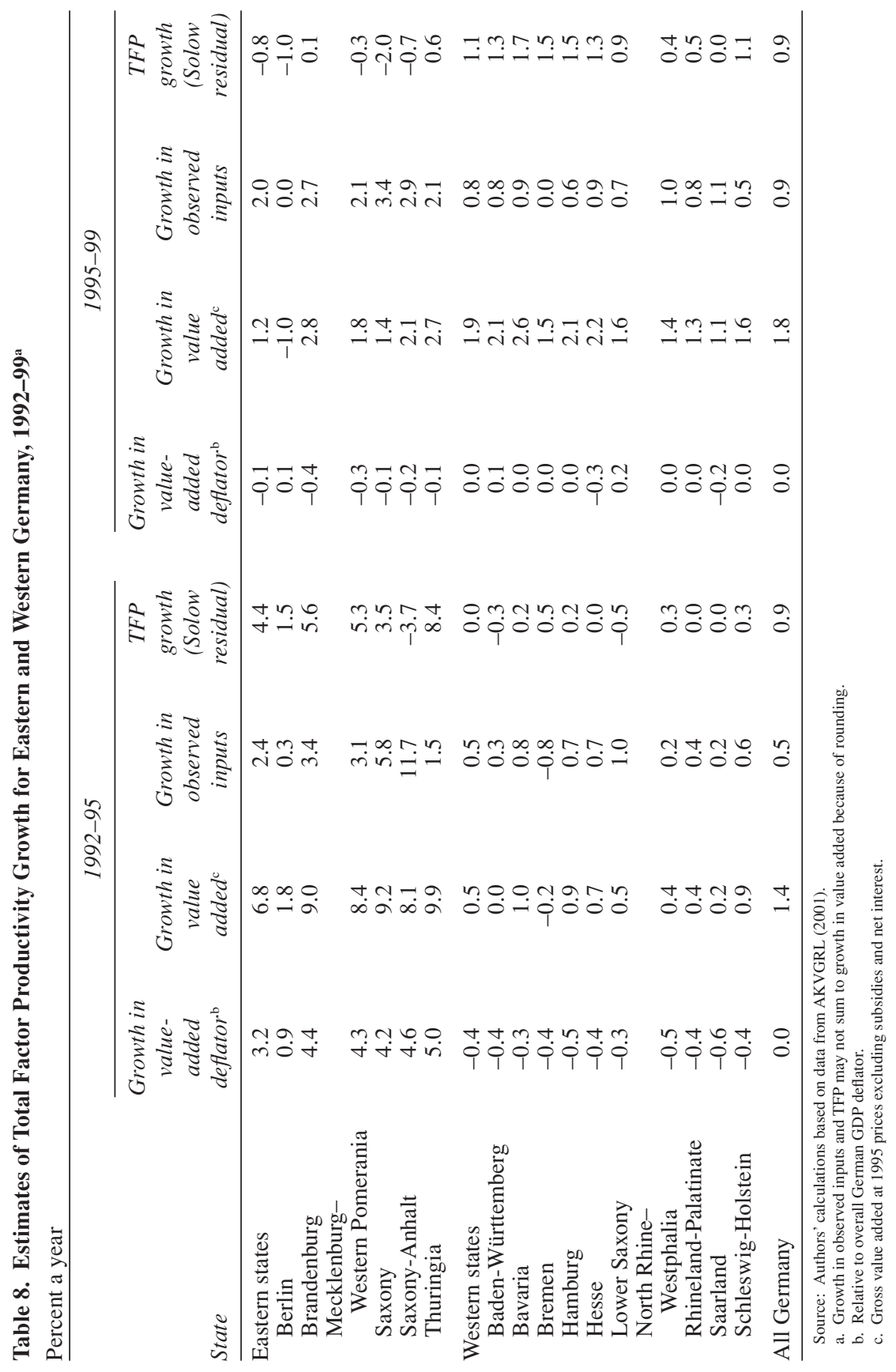


in the east, its quality is almost surely higher than that in the west because it is so much newer.

Several aspects of the quality of labor must be considered. Experience gained under communism may be less valuable than experience gained in a capitalist economy. Using the GSOEP data, Alan Krueger and JörnSteffen Pischke document that the return to (potential) experience in the east fell from 1989 to $1990,{ }^{45}$ and we have confirmed this using our sample and definitions (although the problem arises that only the wage and not its covariates are known for 1989). Curiously, however, Krueger and Pischke also document, using a 1988 dataset, that the return was lower in that year than in 1989. It is thus not quite clear whether the low return in 1990 reflected a decline or not. Nevertheless, the experience gap in favor of the east may be less than it appears. At the same time, case study evidence suggests that, at least in some contexts (and possibly with positively selected workers), the cooperative brigade system under which East German workers operated prepared them well for new production techniques. Eastern workers adapted more readily to the team-based production systems introduced in manufacturing in the 1990s than western workers did. ${ }^{46}$

The schooling system worked somewhat differently in the communist east than in the west; for example, there was less tracking in secondary classroom schooling, and more coordination between the classroom and firm components of apprenticeship training, in East Germany. Apprenticeships generally lasted two years there, compared with three in the west, and took place in less well equipped firms. On the other hand, easterners tended to complete more apprenticeships in high-skill occupations than westerners. Tertiary education in practice was completed in less time in the east, but this reflects to some degree the inefficiencies of the western university system, where students repeat many courses. ${ }^{47}$

\section{Productivity Gaps by Skill Level}

We can exploit the GSOEP data to gain more insights into possible causes of the productivity gap, in particular by measuring how the gap varies with worker skill. We assume that the wage in both east and west represents the marginal product of labor, which will be the measure of pro-

45. Krueger and Pischke (1995).

46. Turner (1998).

47. See Scheuer (1990) and Krueger and Pischke (1995). 
ductivity for the analysis. We also assume that western wages reflect the true market skill of a worker. We assign a skill level to each eastern worker by predicting what a worker with the same characteristics would earn in the west, as described below. We then plot the actual wage that worker earns in the east against the wage predicted in this manner (which we then call skill). If skill were rewarded as in the west, actual wages would cluster along the 45-degree line. In reality, we expect eastern wages to fall below the 45-degree line, indicating a productivity gap, and we are interested in the size of that gap at different skill levels. Since we are conditioning on worker characteristics, differences in composition of the regions' work forces are removed as a source of productivity differences. We cannot, however, condition on capital available to the worker, and so productivity gaps here cannot be thought of as TFP gaps.

To calculate the skill measure, we first perform median log wage regressions for the west, for men and women separately, pooling annual data for 1984 through 1989. A set of "basic" variables is included in all regressions, augmented by one or more (or no) "extended" control variables. The former include year dummies, age, age squared, a dummy for whether the worker is a foreign national, dummies for education levels, and variables interacting the education dummies with age. The extended controls include tenure with the firm and dummies for firm size, industry, and whether the respondent reports being employed part time or sporadically. The coefficients from these regressions are then used to predict the wage that each easterner in the sample would earn in the west, and we take this to be that worker's skill. We set the value of the year dummy for 1988 to 1 for prediction purposes.

Figure 2 shows the results using the extended controls for men and for women, for both 1990 and $1999 .{ }^{48}$ Easterners working in the west are excluded from the eastern sample. Rather than plotting actual eastern wages against measured skill for each individual, we have plotted the median regression line through the observations (solid line) and the associated 95 percent confidence intervals (dotted lines). The 45-degree line is also shown. As expected, the regression line is below the 45-degree line in 1990 for both men and women and is flatter. This indicates that easterners were less productive than westerners, especially at high skill levels

48. Here and in subsequent analyses the 1999 sample of easterners is limited to those residing in the east in June 1990. All the analyses were repeated for a sample covering all workers in the east (including immigrant and commuting westerners and members of a new sample added to refresh the panel). The results are very similar. 
Figure 2. Productivity Gap by Skill for Easterners Working in Eastern Germany, 1990 and $1999^{\mathrm{a}}$

Men, 1990

Actual wage (logarithms)

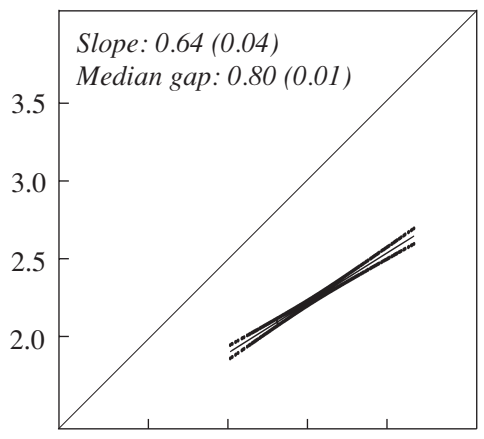

Women, 1990

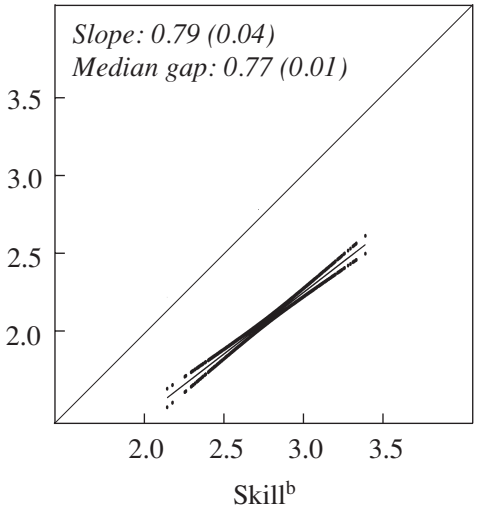

Men, 1999

Actual wage (logarithms)

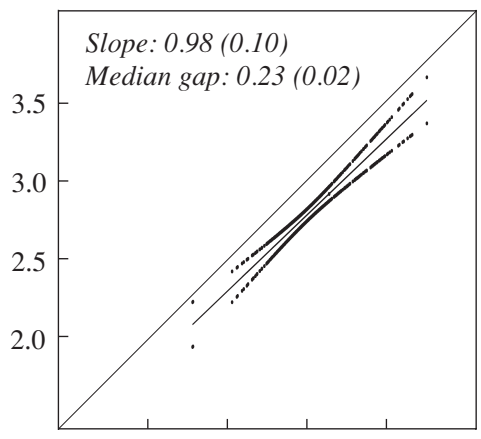

Women, 1999

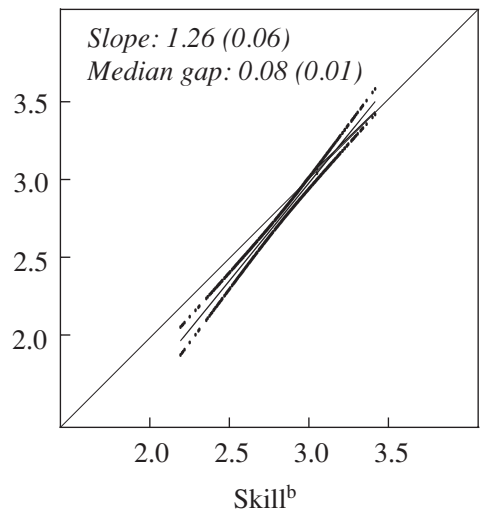

Source: Authors' calculations based on data from the German Socio-Economic Panel.

a. The 45-degree line represents the locus of points where skill is rewarded equally in eastern and western Germany. Standard errors are reported in parentheses, and 95 percent confidence intervals are shown.

b. Wage (in logarithms) predicted for easterners based on western skill coefficients.

(that is, high predicted wages): the return to skill was lower in the east. By 1999, for both men and women, the line has shifted upward and become steeper. The productivity gap has thus clearly diminished, especially for the more skilled: the return to skill has risen. ${ }^{49}$

49. An alternative explanation for the line being flatter than 45 degrees is that the measured components of skill are of inferior but rising quality in the east. For experience, firm 
Each panel in figure 2 indicates the slope of the estimated productivity line (a slope of one would indicate a constant productivity gap by skill), and the log wage gap between the productivity line and the 45-degree line at the median skill level, as well as their standard errors. Men and women both begin with a median gap of about 0.8 ( $80 \mathrm{log}$ points, or a wage ratio of 2.2), which shrinks to 0.23 for men (a gap of 22 percent) and to only 0.08 for women ( 8 percent) in 1999. The slope for male workers rises from 0.64 to 0.98 ; the latter number is not significantly different from one. The slope for females rises from 0.79 to 1.26 , which is significantly greater than one. We also attempted to incorporate bonuses into the wage measure, although this reduced the sample size (results not shown). For 1999 this increases the median gap by 0.02 and raises the female productivity slope to 1.31 and the male slope to 1.05 .

Given the strong labor force attachment of eastern women, it is arguably more appropriate to compare them with western men than with western women. In results using data without bonuses (not shown), we found a slope of 0.77 (with a standard error of 0.06) in 1990 and a gap of 0.88 (0.01). In 1999 the slope was 1.22 (0.08), steeper than for eastern men (although insignificantly), and the gap was smaller (also insignificantly) at $0.20(0.02) .^{50}$

To address the question of how productive eastern workers are in the east, we restricted the analysis in figure 2 to those working there. It might be argued that following up on easterners who have relocated (or are commuting) to the west would reveal more about the true productive potential of easterners. The difficulty is that these workers are not a random sample of easterners but are likely to be positively self-selected, and in any case the sample is small and changes over time. Nevertheless, in figure 3 we repeat the analysis for the sample of easterners working in the west, whether as emigrants or as commuters. For this analysis we simply use nominal wages for all workers, rather than real wages calculated using

size, and to some extent industry, this is really another way of looking at the same phenomenon.

50. By 1999, conditional on characteristics, eastern women earned a statistically insignificant 1 percent more than eastern men working in the east. Franz and Steiner (2000) point out that eastern women benefit from public sector pay scales. They claim, however, that this success is fragile, because of its dependence on makework jobs. Since, in 1999, 50 percent of women worked in the public sector but only 5 percent of women had makework jobs, the claim of fragility seems exaggerated. 
Figure 3. Productivity Gap by Skill for Easterners Working in Western Germany, 1991 and 1999a

Men, 1991

Actual wage (logarithms)

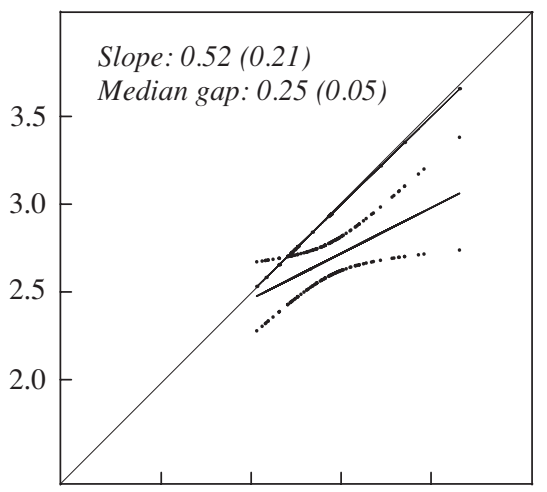

Women, 1991

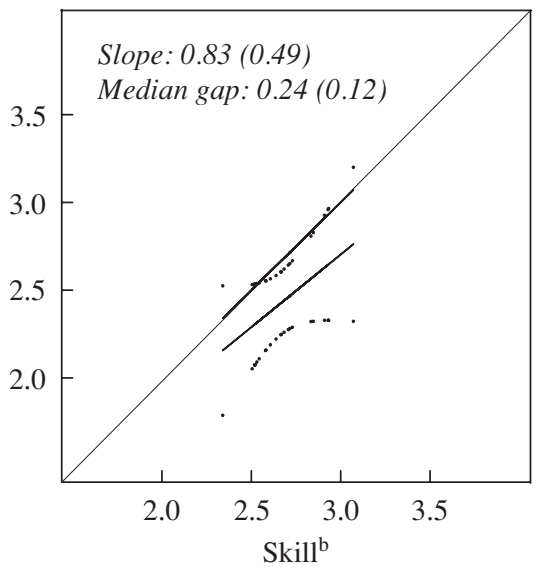

Men, 1999

Actual wage (logarithms)

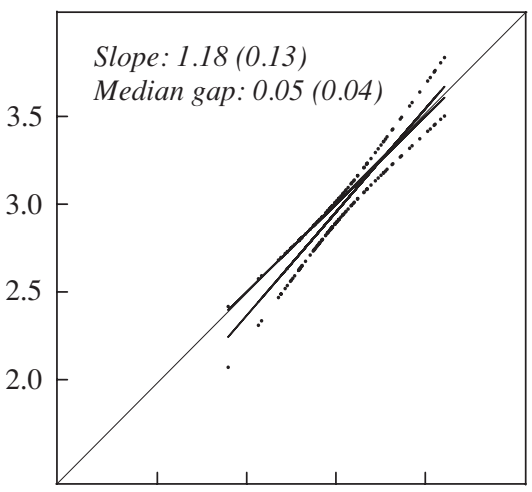

Women, 1999

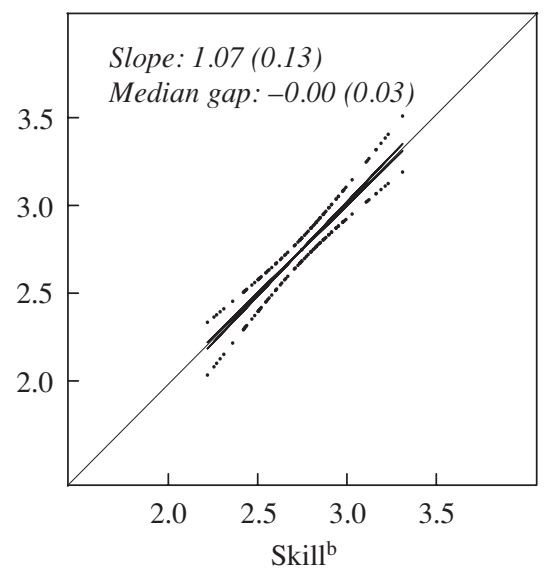

Source: Authors' calculations based on data from the German Socio-Economic Panel.

a. The 45-degree line represents the locus of points where skill is rewarded equally in eastern and western Germany. Standard errors are reported in parentheses, and 95 percent confidence intervals are shown.

b. Wage (in logarithms) predicted for eastern emigrants and commuters using western skill coefficients. 
separate deflators for east and west. The initial year is 1991, because by construction of the sample there are no emigrants in 1990, and because the commuting question was first asked in 1991. In 1991 eastern men had a very low return to skill (a slope of 0.52 ) and a 0.25 median gap (25 log points). Large standard errors make it difficult to say anything about eastern women in 1991. By 1999, however, both the slopes and the gaps are insignificant for both men and women.

\section{Implications of a Constant Productivity Gap by Skill Level}

Overall, it seems appropriate to characterize the eastern return to skill in 1999 as fairly similar to that in the west, with the productivity gap thus constant across skill levels. This constancy rules out certain possible explanations for the remaining productivity gap. It is unlikely to be due to deficiencies in capital, for example, which would be expected to lead to a larger productivity gap for the more skilled. We have deliberately not set a moving target for the east, but rather have compared it with the preunification West Germany of 1988. Results by Henning Klodt imply that, by 1999 , the east had reached the western capital-labor ratio of $1988 .{ }^{51} \mathrm{~A}$ similar capital-labor ratio does not imply, however, that eastern capital is at a level consistent with full convergence, because eastern employment is too low. The inefficiencies, discussed in the next section, that cause employment to be low will also have implications for the capital stock.

It is also unlikely that the remaining productivity gap could be explained by a mismatch between eastern skills and imported western technology, since this is likely to affect different skill levels differently. ${ }^{52}$ We therefore concentrate below on explanations that could plausibly affect the productivity of all skills equally, such as differences in infrastructure and in business skills.

It is important to bear in mind that the wage structure and the decline in employment in the east are unlikely to be independent of one another. For example, Hunt documents the large decline in the male-female wage gap in eastern Germany and shows that several percentage points of the relative wage gain for women are due to employment declines among lowpaid women..$^{53}$ The employment decline will affect the median gap in the

51. Klodt (2000).

52. See Acemoglu and Zilibotti (2001).

53. Hunt (forthcoming). 
graph if such declines are disproportionately among people whose actual wage is above or below their predicted wage. If this selection effect varies by skill, the slope of the line could be affected, too.

\section{Other Factors in the TFP Growth Slowdown}

LABOR HOARDING AND THE BUSINESS CYCLE. The data in table 1 show that the eastern states experienced a sharp slowdown in growth starting in 1995. In the following year unemployment began rising. One standard explanation of the TFP slowdown might therefore be labor hoarding, as firms attempt to hold onto their best workers and avoid severance costs in the event the downturn is brief.

To account for possible effects of the business cycle on the Solow residual, we regressed the benchmark estimates of the Solow residual summarized in table 8 on a complete set of fixed effects (time and state), plus a set of time effects for eastern Germany, plus contemporaneous and lagged values of the first difference of the logarithm of the number of unemployed in the state. We also interacted the unemployment variables with a dummy for eastern Germany. The regressions reported in columns 9-1 and 9-2 of table 9 show that indeed there is an effect of unemployment. This effect is negative for the west, which is consistent with labor hoarding. For the east, however, the total effect is positive: for the regression in column 9-2, the sum of all four coefficients is positive but insignificantly different from zero $(p=0.061)$. The hoarding effect must be overwhelmed by the impact of firms restructuring and moving to the efficient frontier, which may well be a transitory deviation from western German behavior.

INFRASTRUCTURE. Another candidate explanation for the systemic TFP growth slowdown in eastern Germany after 1995 is the changing trends in the growth of economic infrastructure in the east. By infrastructure we mean the stock of public and semipublic goods that contribute to production outcomes. Examples are highways, roads, bridges, telecommunications networks, airports, and harbor terminals, as well as universities, hospitals, police and fire departments, and utilities (utilities in Germany tend to be publicly funded and highly regulated). Although the point is controversial, there is some evidence that sustained infrastructure investment may promote economic growth. ${ }^{54}$

54. See Aschauer (1989); for evidence on Germany see Seitz (1994). 


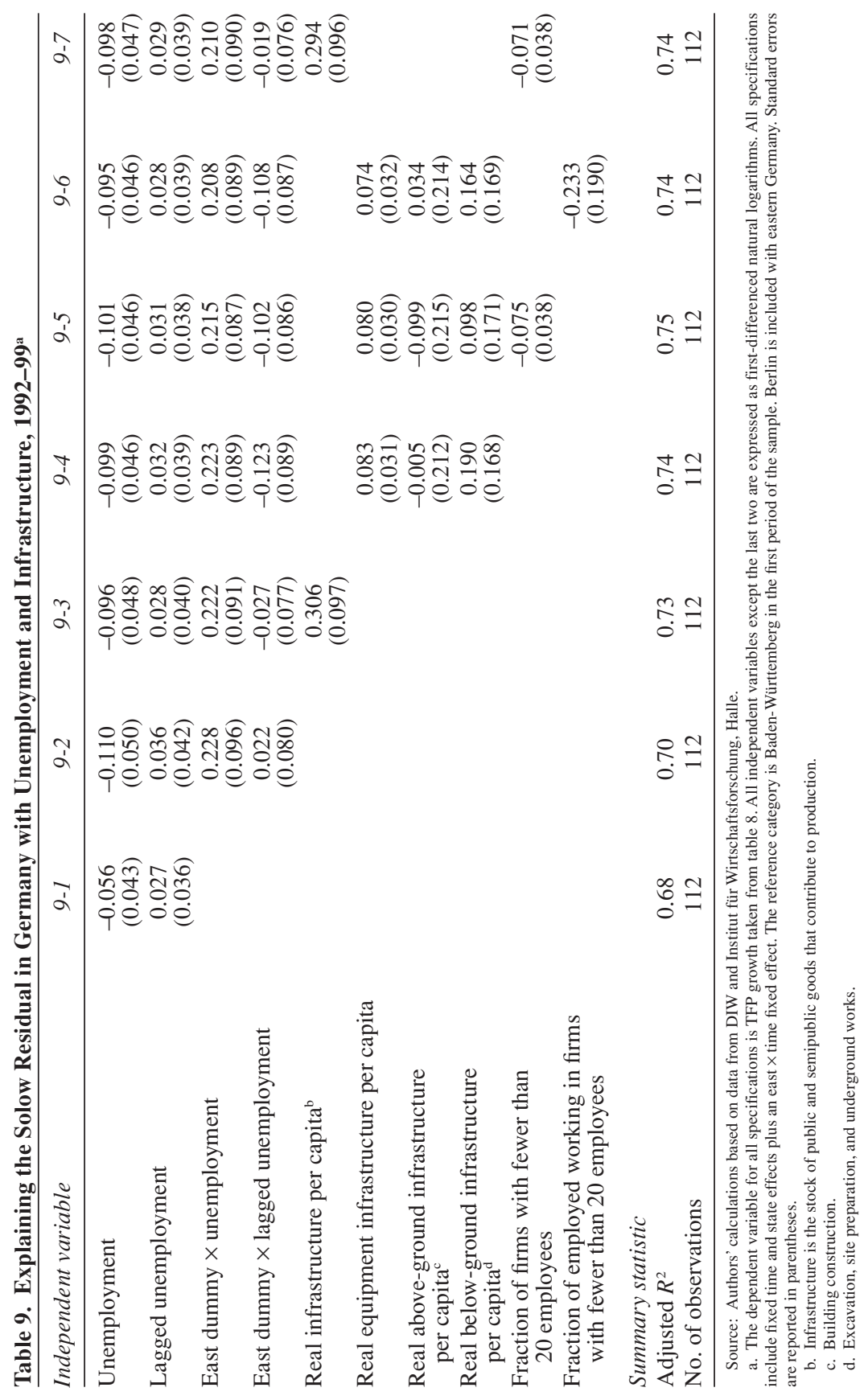


As with private productive capital, it is widely agreed that infrastructure in East Germany in 1990 was severely deficient compared with that in West Germany. Despite immense outlays, infrastructure in the east is often regarded as inferior in the productive dimension. ${ }^{55}$ Moreover, the evidence indicates that a decrease in spending by states and local authorities set in during the mid-1990s. ${ }^{56}$ Because it is thought to affect the productivity of all factors, infrastructural backwardness could affect productivity in a skill-neutral way and thus account for our findings above. In the regressions in columns 9-3 through 9-7 in table 9, therefore, we add the first difference in log per capita infrastructure stocks as estimated by the Deutsches Institut für Wirtschaftsforschung (DIW) ${ }^{57}$ We find a robust positive coefficient on total infrastructure and, when the data are disaggregated, on equipment infrastructure capital stocks (as opposed to streets, buildings, sewerage, and tunnels). The point estimate associates a 10 percent decline in equipment growth — not a large magnitude in recent experiencewith a decline in TFP growth of approximately 0.83 percentage point.

MANAGERIAL TALENT, ENTREPRENEURSHIP, AND MARKETING SKILLS. Certain business skills either did not exist under communism or did not transfer well to the postcommunist period; these deficiencies could explain part of the TFP gap. Authors of case studies have noted that eastern managerial and organizational skills fell short of those in the west in the early years of transition. Managers had to adapt to working in much smaller firms and working more cooperatively with employees. Managers who had been successful under communism also had to deal with workers who resented that fact. The move to capitalism also demanded knowledge of marketing, law, economics, and foreign languages (other than Russian) and a culture of entrepreneurial risk taking. ${ }^{58}$

55. Siedel and Vesper (2000); Vesper (2001). In a controversial pair of studies, the DIW first asserted the existence of an infrastructure shortfall, then partly reversed itself, citing the neglected and large public enterprise sector and consolidating a number of heterogeneous accounts. A robust finding appears to be that a large gap persists in street and road construction, sewage treatment, and schools; in terms of cultural and social infrastructure, in contrast, the east appears to lead the west. Initial estimates of the total infrastructure gap ranged from DM 200 billion to DM 300 billion, but current estimates indicate that it is more likely in the vicinity of DM 160 billion at replacement cost, or roughly DM 10,000 per inhabitant of eastern Germany.

56. Siedel and Vesper (2000); Vesper (2001).

57. Siedel and Vesper (2000); Vesper (2001); unpublished DIW data.

58. This section draws on the case studies of Bode and Hirschmann (1992), Nickel, Kühl, and Schenk (1994), and Turner (1998). 
Many analysts believe these considerations are still relevant a decade later. Joachim Ragnitz argues that a continuing lack of marketing skills leads to eastern products being sold at a discount, which directly influences the productivity statistics. ${ }^{59}$ The interesting question, however, is why such deficiencies have not been remedied in the eleven years since monetary union. A high return to these scarce skills should have induced investment by easterners and perhaps mobility by westerners. In the early transition, western firms sent managers on temporary assignments to the east, and we provide evidence below that easterners were sent west for training. It may be that building up easterners' stock of business knowledge is simply a very slow process, and western managers could be an inefficient solution if they impose management structures that are inappropriate given the skill mix of the workers.

CREDIT CONSTRAINTS. Another hypothesis to explain low productivity in the east is that firms there suffer from credit constraints. This could also have a skill-neutral effect. Doris Neuberger, for example, finds that there is a "finance gap" between eastern and western firms. ${ }^{60}$ In line with the new literature on financial multipliers and credit squeezes, firms tend to get credit as an increasing function of their capitalization, meaning that the new firms in the east are at a natural disadvantage. In a 1998 paper, Lowell Turner cites the example of the Niles machine tools plant in Berlin, which had difficulties obtaining credit before it was privatized in May 1993.

SECTORAL SHIFTS AND FIRM SIZE. Many analysts point to the industrial structure of eastern Germany and the predominance of small firms as reasons for its low productivity. It is well known that observationally similar workers are paid more in larger firms (or at least in large firms that are profitable in market economies) and in certain capital-intensive industries. The GSOEP means in table 7 show that, in 1990, eastern workers tended to be in larger firms than western workers, but by 1999 the reverse was true. Data from the Institut für Wirtschaftsforschung, Halle, confirm this trend.

Table 10 shows a collapse of manufacturing's share in employment to only 15 percent, and a rise in construction's share to 17 percent, in the east in 1995. Employment in services has risen, but its share still lags behind that in the west (some of the rise represents the outsourcing of services that manufacturers used to provide for themselves). The data also show,

59. Ragnitz (1999, 2001).

60. Neuberger (2000). 
Table 10. Composition of Employment and Value Added in Eastern and Western States and Berlin, 1991, 1995, and 2000 ${ }^{\mathrm{a}}$

Percent

\begin{tabular}{|c|c|c|c|c|c|c|}
\hline \multirow[b]{2}{*}{ Sector } & \multicolumn{3}{|c|}{ Employment } & \multicolumn{3}{|c|}{ Value added } \\
\hline & 1991 & 1995 & 2000 & 1991 & 1995 & 2000 \\
\hline \multicolumn{7}{|l|}{ Eastern states excluding Berlin } \\
\hline Agriculture and forestry & 7.3 & 4.0 & 3.6 & 3.4 & 2.3 & 2.4 \\
\hline Industry, excluding construction & 29.3 & 16.9 & 16.1 & 21.6 & 15.4 & 18.6 \\
\hline Manufacturing & 25.8 & 15.0 & 14.8 & 13.7 & 11.5 & 15.2 \\
\hline Construction & 10.3 & 17.4 & 13.4 & 12.2 & 16.9 & 9.6 \\
\hline $\begin{array}{l}\text { Trade, eating and drinking } \\
\text { establishments, transportation }\end{array}$ & 20.5 & 22.4 & 23.7 & 18.1 & 16.3 & 15.8 \\
\hline $\begin{array}{l}\text { Banking and finance, leasing, } \\
\text { business services }\end{array}$ & 6.0 & 9.2 & 11.8 & 12.4 & 20.4 & 26.0 \\
\hline Public and private services & 26.6 & 30.1 & 31.3 & 32.4 & 28.8 & 27.6 \\
\hline \multicolumn{7}{|l|}{ Western states excluding Berlin } \\
\hline Agriculture and forestry & 3.5 & 2.9 & 2.4 & 1.3 & 1.2 & 1.1 \\
\hline Industry, excluding construction & 30.0 & 26.1 & 23.9 & 31.6 & 27.3 & 26.5 \\
\hline Manufacturing & 28.4 & 24.7 & 22.9 & 28.9 & 24.6 & 24.6 \\
\hline Construction & 6.6 & 6.8 & 5.9 & 5.5 & 5.4 & 4.3 \\
\hline $\begin{array}{l}\text { Trade, eating and drinking } \\
\text { establishments, transportation }\end{array}$ & 25.0 & 25.5 & 25.5 & 17.8 & 18.1 & 17.5 \\
\hline $\begin{array}{l}\text { Banking and finance, leasing, } \\
\text { business services }\end{array}$ & 10.3 & 12.0 & 14.8 & 24.8 & 27.7 & 30.7 \\
\hline Public and private services & 24.7 & 26.7 & 27.4 & 19.0 & 20.4 & 19.8 \\
\hline \multicolumn{7}{|l|}{ Berlin } \\
\hline Agriculture and forestry & 6.0 & 6.0 & 5.0 & 0.3 & 0.2 & 0.2 \\
\hline Industry, excluding construction & 20.7 & 14.0 & 11.7 & 20.8 & 15.3 & 14.1 \\
\hline Manufacturing & 18.9 & 12.4 & 10.6 & 18.7 & 13.3 & 12.1 \\
\hline Construction & 7.7 & 9.1 & 7.0 & 6.4 & 7.7 & 4.6 \\
\hline $\begin{array}{l}\text { Trade, eating and drinking } \\
\text { establishments, transportation }\end{array}$ & 26.2 & 24.0 & 22.4 & 17.0 & 16.1 & 14.7 \\
\hline $\begin{array}{l}\text { Banking and finance, leasing, } \\
\text { business services }\end{array}$ & 12.5 & 16.6 & 19.9 & 28.2 & 32.8 & 36.7 \\
\hline Public and private services & 32.2 & 35.7 & 38.5 & 27.4 & 27.8 & 29.7 \\
\hline
\end{tabular}

Source: Authors' calculations based on data from AKVGRL (2001).

a. Numbers may not sum to 100 because of rounding.

however, that the construction boom has peaked. Thus the relatively constant level of employment since 1993 conceals significant sectoral shifts. It is interesting to note, also in table 10, that the shifts in value added by sector have sometimes exceeded the shifts in employment. These shifts are the most promising sign we can detect that more aggregate indicators for eastern Germany may yet resume convergence. 
It is not clear to what extent small firms and a poor industrial mix are causes or symptoms of slow convergence. Firms in the east may be small because they are unsuccessful, possibly specializing in nontradables or small markets for goods with high transport costs ${ }^{61}$ Alternatively, their small size may reflect policy errors, such as policies that keep wages artificially high, that have led to low investment from abroad. As for industrial composition, if it is not a policy choice, noting that the industrial mix is poor may not advance analysis very far. Hans-Werner Sinn and Klodt, however, both stress that to some degree the industrial mix has indeed been a policy choice through the medium of subsidies to capital investment. ${ }^{62}$

Our wage-based analysis controlled for industry and firm size directly. Controls for industry and firm size reduce the 1999 median productivity gaps by only 0.01 (results not shown). In the last columns of table 9 we look explicitly for the effect of firm size on TFP growth. Although weakly significant, the association is hardly large: an observed move in the share of small firms in the east (from 1.4 percent in 1991 to 6.6 percent in 1999) is linked to a decrease in growth of 0.37 percent (column 9-7). By contrast, Ragnitz finds, using a different methodology, that firm size alone accounts for 17 percentage points of the raw productivity gap. ${ }^{63}$

Despite our finding that industry and firm size are not so important in a static accounting sense, we believe that insights for long-run growth can be gained by considering the industry mix. Hunt observes that, after the first year of transition, incentives to change jobs and industries appear to have been low, and job-changing rates fell. ${ }^{64}$ Using GSOEP data, she calculates that over 1990-96 only 18 percent of real wage growth went to job changers within the east, and 7 percent was due to movement to and from jobs in the west. This is surprisingly low compared with the 22 percent of real wage growth in the west that went to job changers. In the first year of transition, voluntary movers within the east gained 15 percent more than similar workers who stayed with the same employer, and the whole gain was due to changing industry. Wages continued to rise subsequently, but movers experienced no significant gain over stayers.

These results suggest that wage growth patterns after 1991 were not conducive to sectoral shifts, as stayers were too well rewarded. For the

61. This has been suggested by von Hagen and Strauch (2000).

62. Sinn (1995); Klodt (2000).

63. Ragnitz (2001).

64. Hunt (2001a). 
period 1990-93 it may be appropriate to think of the labor unions as choosing wages (this is discussed further below). In some industries wage increases for 1990-94 were laid out in advance as early as 1990. The unions, bargaining at the industry level, did take the industries' prospects into account when setting wages, but it is nevertheless possible that they did not pick the right relative wages across industries. High wages in "bad" industries could have delayed restructuring in a fashion similar to that in the model of Philippe Aghion and Olivier Blanchard. ${ }^{65}$ However, after 1993 the power of the unions declined significantly. In order to inculpate the unions, it is necessary to argue that nominal wage rigidities and low inflation, coupled with a high overall wage level, made it hard for relative wages to adjust.

Could the overall TFP slowdown be concealing very different trends by sector ${ }^{66}$ In particular, if construction experienced a fall in TFP similar to the fall in its labor productivity, it could obscure TFP growth in other sectors. In addition, government and other state service sectors may have seen slower growth. Unfortunately, there are no good benchmarks for sectoral capital stocks that are also broken down into equipment and structures. We performed a cruder Solow calculation using annual estimates by Bernd Görzig and Gerda Noack of the total capital stock for "producing industry and manufactures," an aggregate that includes mining, manufacturing, and the energy sector but excludes construction. ${ }^{67}$ The results show a pattern almost identical to that of the broader economy: TFP growth during 1993-95 averaged 11.8 percent a year but fell to 4.3 percent a year during 1996-98, with a value of 0.5 percent in 1998 .

MIGRATION AND COMPOSITION EFFECTS. It may be that migration has removed the most productive individuals from the eastern sample. In this respect we can identify an important link between productivity and migration: if the most productive individuals leave or have the greatest propensity to leave, the Solow residual as calculated in table 8 will mismeasure inputs (by failing to weight workers by their human capital). An obvious modification is to redo the Solow analysis for more disaggregated labor types. Using employment data by age available from the German Mikrozensus from 1991 on, we construct an extended version of the Solow

65. Aghion and Blanchard (1994).

66. This question is raised by Holger Wolf in his comment.

67. Görzig and Noack (1999). 
decomposition, which weights different employment-age groups by their share of labor income, estimated using GSOEP data (for details see the appendix). The results, presented in table 11, show little difference from the unadjusted results.

\section{Assessing Labor Market Performance}

Low output per capita may also reflect an inability to mobilize labor resources. We now examine labor market issues in eastern Germany, with an emphasis on whether wages are too high to allow full employment. We begin by discussing how wages came to be so high, and then we assess the structure and level of wages and other issues related to unemployment.

\section{Why Did Wages Initially Rise So Quickly Given Low Productivity?}

It is generally assumed that, in the early years of transition, labor unions were able to choose the level of wages. The western labor unions established themselves in the east beginning in 1990, replacing the disbanded communist union, and quickly built up a large membership. The West German system of industrial relations was introduced, and the new, westernled unions bargained at the industry level. The eastern enterprises were initially unprivatized, and so the unions' bargaining partners were the existing enterprise managers, advised in some cases by western employers. In certain industries periodic wage increases were immediately agreed to as far ahead as 1994, when, in the metalworking industry, parity with the west was supposed to be reached. However, an employers' revolt in 1993 restrained the growth of wages, and thereafter the unions moved onto the defensive. Some firms began illegally paying below the negotiated wage, some left the employers' federation to avoid being bound by the union agreements, and new firms declined to join the federation.

The motivations of the managers and the western employers are not clear, but it seems likely they were less inclined to resist wage increases than private enterprise owners would have been. The unions were certainly motivated in part by concerns for equity and the welfare of eastern workers. Wage rises benefited both those keeping their jobs and those who would have lost their jobs anyway, since losing a higher-wage job entitled them to higher unemployment benefits. At the same time, the unions 
Table 11. Estimates of Total Factor Productivity Using Alternative Labor Inputs, 1992-99

Percent a year

\begin{tabular}{|c|c|c|c|c|}
\hline \multirow[b]{2}{*}{ State } & \multicolumn{2}{|c|}{$1992-95$} & \multicolumn{2}{|c|}{ 1995-99 } \\
\hline & $\begin{array}{c}\text { Benchmark } \\
\text { estimate }^{\mathrm{a}}\end{array}$ & $\begin{array}{c}\text { With } \\
\text { employment } \\
\text { age correction }\end{array}$ & $\begin{array}{c}\text { Benchmark } \\
\text { estimate }^{\mathrm{a}}\end{array}$ & $\begin{array}{c}\text { With } \\
\text { employment } \\
\text { age correction }\end{array}$ \\
\hline Eastern states & 4.4 & 4.3 & -0.8 & -0.6 \\
\hline Berlin & 1.5 & 1.6 & -1.0 & -0.7 \\
\hline Brandenburg & 5.6 & 5.5 & 0.1 & -0.7 \\
\hline Mecklenburg- & & & & \\
\hline Western Pomerania & 5.3 & 5.2 & -0.3 & 0.4 \\
\hline Saxony & 3.5 & 3.5 & -2.0 & -1.8 \\
\hline Saxony-Anhalt & -3.7 & -3.4 & -0.7 & -0.3 \\
\hline Thuringia & 8.4 & 7.5 & 0.6 & 0.7 \\
\hline Western states & 0.0 & -0.5 & 1.1 & 0.9 \\
\hline Baden-Württemberg & -0.3 & -0.8 & 1.3 & 1.3 \\
\hline Bavaria & 0.2 & -0.2 & 1.7 & 1.7 \\
\hline Bremen & 0.5 & -0.5 & 1.5 & 1.8 \\
\hline Hamburg & 0.2 & -0.5 & 1.5 & 1.3 \\
\hline Hesse & 0.0 & -0.4 & 1.3 & 1.2 \\
\hline Lower Saxony & -0.5 & -1.1 & 0.9 & 0.5 \\
\hline North Rhine-Westphalia & 0.3 & -0.4 & 0.4 & 0.4 \\
\hline Rhineland-Palatinate & 0.0 & -0.5 & 0.5 & 0.0 \\
\hline Saarland & 0.0 & 0.2 & 70.0 & -0.7 \\
\hline Schleswig-Holstein & 0.3 & -0.6 & 1.1 & 1.3 \\
\hline All Germany & 0.9 & 0.5 & 0.9 & 0.8 \\
\hline
\end{tabular}

Source: Authors' calculations based on data from AKVGRL (2001) and the German Federal Statistical Office.

a. From table 8. Uses one homogeneous labor input.

b. Employment data are disaggregated into four age groups (see appendix for details).

may also have been acting in the perceived interests of western workers. They may have wanted to reduce competition from the east by raising production costs there and by reducing migration flows to the west. ${ }^{68}$

In addition to the labor unions, another intervention was the introduction of the western welfare and social insurance systems. These presumably raised reservation wages and allowed unions to bargain higher wages for the low skilled. We have already mentioned the channel through which unemployment insurance allowed this. The basic means-tested welfare

68. See Burda and Funke (2001) for more details on how and why wages rose. 
allowance (Sozialhilfe) was introduced at a level below that in the richer west but was soon raised to the same level.

One could argue, however, that even in the absence of powerful unions and generous welfare benefits, wages would have risen greatly as integration proceeded. Factor price equalization through free trade would have led to equal wages once the technologies employed were the same and factor endowments sufficiently similar. The rapid transfer of technology and capital from west to east would have boosted the wages of workers with similar skill endowments. Furthermore, the option of moving to the west meant that to some degree the western wage provided a reservation wage. A naïve interpretation of figure 3 suggests that, in 1991, easterners who moved could have earned about 75 percent of western wages. Turner provides evidence that some large manufacturing employers supported large wage rises as a way of retaining skilled workers who might otherwise emigrate. ${ }^{69}$ Nevertheless, the unprecedented employer revolt in 1993, when employers' federations abrogated their collectively bargained agreements, and the fact that in this period the firm-based works councils accepted slower wage growth to save jobs, suggest that wages grew faster than they would have in the absence of institutional intervention.

A good example of the difference mobility makes is the fact that the ambitious aim of wage equality across eastern and western Germany by 1995 has succeeded only in Berlin, and even there convergence has been incomplete in sectors where mobility is low or the concentration of specific human and physical capital is high. Table 12 shows earnings ratios between East and West Berlin in various sectors for 1993-2000. Convergence has been achieved in the printing and paper industries, while machinery and construction are the laggards, but even there eastern wages are 81 percent of western wages. It is not clear whether this is due to lagging capital intensity or, in the case of construction, to public works procurement policies and tax subsidies.

\section{Is the Wage Structure Inappropriate?}

The consequences of high wages depend on why wages are high. In the simplest model, unemployment results if unions push wages above the market-clearing level. If, as is commonly the case in rich countries,

69. Turner (1998). 
Table 12. Convergence of Earnings in Selected Industries in East Berlin, 1993-2000 Percent of West Berlin average

\begin{tabular}{lrrrrrr}
\hline Industry & 1993 & 1995 & 1997 & 1998 & 1999 & 2000 \\
\hline Chemicals & 63.2 & 69.7 & 81.7 & 79.9 & n.a. & n.a. \\
Construction & 81.3 & 83.8 & 85.0 & 89.5 & 86.2 & 81.4 \\
Electricity, gas, water & 74.5 & 88.3 & 99.0 & 98.8 & n.a. & 96.6 \\
Electronic equipment, office & & & & & & \\
$\quad$ machinery, data processing & 79.2 & 89.5 & 93.2 & 91.9 & 92.0 & 91.1 \\
Food and kindred products & 69.7 & 77.8 & 89.8 & 92.9 & 94.8 & 94.5 \\
Machinery & 71.0 & 77.8 & 81.1 & 83.0 & 80.0 & 81.4 \\
Printing and paper & 74.3 & 93.6 & 98.8 & 107.7 & 112.5 & 100.8 \\
\hline
\end{tabular}

Source: Authors' calculations based on data from the Berlin Statistical Office.

a. Nominal gross monthly earnings.

unions have a distaste for wage inequality and raise the wages of the less skilled more, unemployment will be higher for these workers. However, more sophisticated models can be devised in which the union-initiated wage rise pushes the economy onto a high-productivity path because of responses in human capital investment. ${ }^{70}$ If instead wages are high because reservation wages have risen above the market-clearing wage, employment will fall, but there will be no unemployment. An exception would be if unemployment were due in part to efficiency wages. In this case a rise in the reservation wage would raise the wage paid and raise unemployment. ${ }^{71}$ Given the possible link between wages and unemployment insurance, it is worth noting that, under most circumstances, theory predicts that unemployment insurance will speed a successful transition. ${ }^{72}$

In the integration context, wages could rise as a result of factor price equalization, which would be an efficient outcome. Finally, we have already discussed the possibility that inappropriate sectoral differentiation of wages may prevent the reallocation of labor across sectors, which in the longer run would prevent a recovery of employment.

The behavior of wages and employment at various skill levels should reveal more about the source of unemployment. The first two rows of table 13 show 90-10 log wage differentials (the difference between the log wage at the 90th percentile of the wage distribution and that at the 10th percentile) within eastern and western Germany, for both men and women,

70. Burda and Funke (2001).

71. We thank Janet Yellen for this observation.

72. See Roland (2000). Boeri (2000) provides empirical support for this argument. 
Table 13. Wage Inequality in Eastern and Western Germany, 1990-99a

Difference between 90 th percentile and 10th percentile log wages

\begin{tabular}{|c|c|c|c|c|c|c|}
\hline \multirow[b]{2}{*}{$\begin{array}{l}\text { Type of inequality } \\
\text { and year }\end{array}$} & \multicolumn{3}{|c|}{ Eastern } & \multicolumn{3}{|c|}{ Western } \\
\hline & Men & Women & $\begin{array}{l}\text { Men and } \\
\text { women }\end{array}$ & Men & Women & $\begin{array}{l}\text { Men and } \\
\text { women }\end{array}$ \\
\hline \multicolumn{7}{|l|}{ Observed $^{\mathrm{b}}$} \\
\hline 1990 & 0.65 & 0.72 & 0.75 & 0.87 & 0.94 & 0.99 \\
\hline 1999 & 0.91 & 1.00 & 0.96 & 0.88 & 0.99 & 0.95 \\
\hline Change & 0.26 & 0.28 & 0.21 & 0.01 & 0.05 & 0.04 \\
\hline \multicolumn{7}{|l|}{ Between-group ${ }^{\mathrm{c}}$} \\
\hline 1990 & 0.40 & 0.52 & 0.52 & 0.64 & 0.72 & 0.76 \\
\hline 1999 & 0.59 & 0.84 & 0.71 & 0.76 & 0.63 & 0.68 \\
\hline Change & 0.19 & 0.32 & 0.19 & 0.12 & -0.09 & -0.08 \\
\hline \multicolumn{7}{|l|}{ Within-group $^{\mathrm{d}}$} \\
\hline 1990 & 0.56 & 0.54 & 0.55 & 0.60 & 0.66 & 0.64 \\
\hline 1999 & 0.69 & 0.69 & 0.70 & 0.62 & 0.76 & 0.70 \\
\hline Change & 0.13 & 0.15 & 0.15 & 0.02 & 0.10 & 0.06 \\
\hline
\end{tabular}

Source: Authors' calculations based on data from the German Socio-Economic Panel.

a. East Berlin is included with eastern Germany and West Berlin with western Germany. Sample weights are used for western Germany. Table 7 reports characteristics of the sample.

b. Actual difference between hourly wages (expressed in logarithms) paid at the 90 th percentile and those paid at the 10th percentile.

c. Difference in hourly wages predicted by regressions for 1990 and 1999 that explain log hourly wages with age, age squared, education, part-time and sporadic work, tenure, firm size, industry dummies, and, for the west, a dummy for foreign nationals.

d. Difference in the residuals from the above regressions.

in both 1990 and 1999. The table shows that eastern inequality has reached the stable western level, ${ }^{73}$ and thus no signs of institutional interference in the convergence to western inequality.

We can probe further by looking at the inequality of predicted wages (between-group inequality) and the inequality of residuals (within-group inequality), based on a log wage regression. Between-group inequality refers to inequality between groups of workers with the same observable characteristics, whereas within-group inequality reflects inequality within these groups. The last two panels of table 13 show results based on mean regressions for east and west, using the set of control variables including tenure, firm size, industry, and part-time status. Eastern men and women have similar increases in the within-group differential of 0.13 to 0.15 , with the result that within-group inequality is 0.69 for both sexes. This value is

73. Using data for men only, Burda and Schmidt (1997) and Prasad (2000) also document a remarkably stable western German wage structure in the 1980s and 1990s, despite the turbulence occurring in the east and migration to the west. 
above that for western men and below that for western women. Betweengroup inequality rises much more for eastern women than for eastern men, leaving eastern women with the highest between-group inequality in 1999 and eastern men with the lowest. This is consistent with the results on the returns to skill shown in figure 2. Decomposing the variance of log wages into additive between- and within-group components reveals that the rise in eastern inequality is due in equal parts to between- and within-group inequality (results not shown).

Changes in between- and within-group inequality can be due to changes in returns or changes in endowments (that is, worker characteristics). We can quantify the contribution of each by performing Oaxaca decompositions. ${ }^{74}$ The change in the mean eastern log wage $(\bar{w})$ may be decomposed into a change in mean characteristics $(\bar{X})$ and a change in the returns to those characteristics $(\beta)$ :

$$
\bar{w}_{t+1}-\bar{w}_{t}=\bar{X}_{t+1} \beta_{t+1}-\bar{X}_{t} \beta_{t}=\left(\bar{X}_{t+1}-\bar{X}_{t}\right) \beta_{t}+\bar{X}_{t+1}\left(\beta_{t+1}-\beta_{t}\right) .
$$

We performed Oaxaca decompositions for men and women separately, based on mean log wage regressions for 1990 and 1999. These regressions are limited to a few simple control variables (age, age squared, education dummies, and dummies for part-time or sporadic employment); others also include tenure with the firm, or also include tenure, firm size dummies, and industry dummies. The results (table 14) show a rise in the mean log wage of 0.56 for men and 0.71 for women. The next two rows report results from the decomposition of the wage increase into changes in the observed characteristics and changes in their return. The rise in wages is almost entirely due to changes in the return to characteristics, which includes the coefficient on the constant term. In the regressions with the complete set of controls, changes in average characteristics tend rather to reduce wages slightly, because of the reduction in tenure and firm size. ${ }^{75}$

Straightforward log wage regressions show most easily which components of skill are behind the rise in return seen in figure 2 and table 14, and the rise in between-group inequality seen in table 13 . We present results in table 15 for both east and west, for men and women separately. The eastern regressions are for 1990 and 1999, whereas for consistency with the

74. See Oaxaca (1973) and Oaxaca and Ransom (1994).

75. See Burda and Schmidt (1997) and Franz and Steiner (2000) for more extensive Oaxaca analyses. 
Table 14. Oaxaca Decomposition of Hourly Wages for Eastern Germany, 1990-99a

\begin{tabular}{|c|c|c|c|c|c|c|}
\hline \multirow[b]{2}{*}{ Change in } & \multicolumn{3}{|c|}{ Men, controlling for } & \multicolumn{3}{|c|}{ Women, controlling for } \\
\hline & $\begin{array}{c}\text { Age, } \\
\text { education, } \\
\text { part time }^{\mathrm{b}}\end{array}$ & $\begin{array}{l}\text { Same + } \\
\text { tenure }^{\mathrm{c}}\end{array}$ & $\begin{array}{c}\text { Same + } \\
\text { tenure, } \\
\text { firm size, } \\
\text { industry }^{\mathrm{d}}\end{array}$ & $\begin{array}{c}\text { Age, } \\
\text { education, } \\
\text { part time }^{\mathrm{b}}\end{array}$ & $\begin{array}{l}\text { Same + } \\
\text { tenure }^{\mathrm{c}}\end{array}$ & $\begin{array}{c}\text { Same + } \\
\text { tenure, } \\
\text { firm size, } \\
\text { industry }^{\mathrm{d}}\end{array}$ \\
\hline Average wage & 0.56 & 0.56 & 0.56 & 0.71 & 0.71 & 0.71 \\
\hline $\begin{array}{l}\text { Observable } \\
\text { characteristics }\end{array}$ & 0.04 & -0.02 & -0.06 & 0.04 & 0.01 & -0.03 \\
\hline $\begin{array}{l}\text { Return to } \\
\text { characteristics }\end{array}$ & 0.52 & 0.59 & 0.62 & 0.67 & 0.70 & 0.74 \\
\hline $\begin{array}{l}\text { Source: Authors' calcu } \\
\text { a. Sample includes wo } \\
\text { For } 1990 \text { there are } 992 \text { obs } \\
\text { is included with eastern G } \\
\text { b. Controls for age and } \\
\text { c. Adds tenure in mont } \\
\text { d. Adds firm size and } \\
\text { e. Expressed in logaritl }\end{array}$ & $\begin{array}{l}\text { ions based on da } \\
\text { ers aged eightee } \\
\text { vations for men } \\
\text { nany and West } \mathrm{F} \\
\text { e squared and ir } \\
\text { ustry dummies. } \\
\text { s. }\end{array}$ & $\begin{array}{l}\text { from the Ge } \\
\text { o fifty-four } \\
1,039 \text { for } \\
\text { lin with we } \\
\text { udes dumm }\end{array}$ & $\begin{array}{l}\text { are not app } \\
\text { en; for } 1999 \\
\text { Germany. } \\
\text { or education }\end{array}$ & $\begin{array}{l}\text { ic Panel. } \\
\text { ces, self-empl } \\
\text { are } 528 \text { for me }\end{array}$ & $\begin{array}{l}\text {, or employ } \\
\text { d } 564 \text { for w } \\
\text { dic work. }\end{array}$ & $\begin{array}{l}\text { n agriculture. } \\
\text { n. East Berlin }\end{array}$ \\
\hline
\end{tabular}

figures the western regressions use preunification data. A disadvantage of the smaller sample sizes for the east, especially when split by sex, is that standard errors are somewhat large, so that not all the changes discussed are statistically significant. ${ }^{76}$

The return to age (at age thirty-five, reported at the bottom of the table) has risen considerably for eastern men and women, to equal the return for western men (0.011). The return to schooling in the east, in contrast, has changed little, except that the quality of the omitted apprenticeship category has risen for women because of selection in employment. ${ }^{77}$ The return to vocational training is higher in the east, whereas the return to a university education is similar for both sexes in both east and west. The return to tenure has risen in the east, especially for men. It is about 0.07 percent a month in 1999 for all groups except western men, for whom it is lower. The return to firm size has risen for both men and women in the east, and that for men may be slightly higher than in the west.

It seems safe to conclude that the rise in the eastern return to skill represents a rise in the return to age or experience, as well as increases in the returns to tenure and firm size. It is more difficult to assess returns to industry, and we do not attempt it. Generally, wage regressions and the

76. A large literature performs similar regressions. See Franz and Steiner (2000) for a recent example.

77. This argument is based on Hunt (forthcoming). 
Table 15. Explaining Wages in Eastern and Western Germany with Age, Education, Employment Status, and Firm Size ${ }^{\mathrm{a}}$

\begin{tabular}{|c|c|c|c|c|c|c|}
\hline \multirow[b]{3}{*}{ Independent variable } & \multicolumn{4}{|c|}{ Eastern } & \multicolumn{2}{|c|}{ Western } \\
\hline & \multicolumn{2}{|c|}{ Men } & \multicolumn{2}{|c|}{ Women } & \multirow{2}{*}{$\begin{array}{c}\text { Men, } \\
1984-89\end{array}$} & \multirow{2}{*}{$\begin{array}{l}\text { Women, } \\
\text { 1984-89 }\end{array}$} \\
\hline & 1990 & 1999 & 1990 & 1999 & & \\
\hline Age & $\begin{array}{c}0.024 \\
(0.007)\end{array}$ & $\begin{array}{l}0.095 \\
(0.016)\end{array}$ & $\begin{array}{c}0.024 \\
(0.006)\end{array}$ & $\begin{array}{c}0.090 \\
(0.016)\end{array}$ & $\begin{array}{l}0.048 \\
(0.003)\end{array}$ & $\begin{array}{c}0.044 \\
(0.004)\end{array}$ \\
\hline Age squared ${ }^{\mathrm{b}}$ & $\begin{array}{c}-0.028 \\
(0.009)\end{array}$ & $\begin{array}{c}-0.001 \\
(0.016)\end{array}$ & $\begin{array}{c}-0.030 \\
(0.009)\end{array}$ & $\begin{array}{c}-0.001 \\
(0.000)\end{array}$ & $\begin{array}{c}-0.053 \\
(0.005)\end{array}$ & $\begin{array}{c}-0.055 \\
(0.006)\end{array}$ \\
\hline $\begin{array}{l}\text { General schooling in } \\
\text { Germany }\end{array}$ & $\begin{array}{c}-0.194 \\
(0.051)\end{array}$ & $\begin{array}{c}0.070 \\
(0.077)\end{array}$ & $\begin{array}{l}-0.180 \\
(0.034)\end{array}$ & $\begin{array}{c}-0.123 \\
(0.089)\end{array}$ & $\begin{array}{c}-0.117 \\
(0.014)\end{array}$ & $\begin{array}{c}-0.136 \\
(0.014)\end{array}$ \\
\hline $\begin{array}{l}\text { General schooling } \\
\text { abroad }\end{array}$ & & & & & $\begin{array}{c}-0.023 \\
(0.014)\end{array}$ & $\begin{array}{l}-0.066 \\
(0.021)\end{array}$ \\
\hline University education & $\begin{array}{c}0.290 \\
(0.028)\end{array}$ & $\begin{array}{l}0.346 \\
(0.046)\end{array}$ & $\begin{array}{c}0.419 \\
(0.029)\end{array}$ & $\begin{array}{l}0.293 \\
(0.054)\end{array}$ & $\begin{array}{c}0.336 \\
(0.014)\end{array}$ & $\begin{array}{c}0.266 \\
(0.023)\end{array}$ \\
\hline Vocational training & $\begin{array}{c}0.142 \\
(0.022)\end{array}$ & $\begin{array}{c}0.153 \\
(0.040)\end{array}$ & $\begin{array}{c}0.250 \\
(0.020)\end{array}$ & $\begin{array}{c}0.163 \\
(0.040)\end{array}$ & $\begin{array}{c}0.066 \\
(0.011)\end{array}$ & $\begin{array}{l}0.062 \\
(0.015)\end{array}$ \\
\hline Civil service training & & & & & $\begin{array}{l}0.092 \\
(0.020)\end{array}$ & $\begin{array}{l}-0.100 \\
(0.041)\end{array}$ \\
\hline Foreign national & & & & & $\begin{array}{c}-0.084 \\
(0.010)\end{array}$ & $\begin{array}{c}-0.082 \\
(0.016)\end{array}$ \\
\hline Employed part time & $\begin{array}{c}-0.288 \\
(0.104)\end{array}$ & $\begin{array}{c}0.036 \\
(0.130)\end{array}$ & $\begin{array}{c}-0.103 \\
(0.019)\end{array}$ & $\begin{array}{c}-0.106 \\
(0.041)\end{array}$ & $\begin{array}{c}-0.255 \\
(0.041)\end{array}$ & $\begin{array}{c}-0.075 \\
(0.012)\end{array}$ \\
\hline $\begin{array}{l}\text { Employed } \\
\text { sporadically }\end{array}$ & & $\begin{array}{c}-0.634 \\
(0.244)\end{array}$ & & $\begin{array}{l}-0.400 \\
(0.119)\end{array}$ & $\begin{array}{l}-0.310 \\
(0.072)\end{array}$ & $\begin{array}{c}-0.189 \\
(0.028)\end{array}$ \\
\hline Tenure (months) ${ }^{\mathrm{b}}$ & $\begin{array}{c}0.019 \\
(0.010)\end{array}$ & $\begin{array}{c}0.065 \\
(0.019)\end{array}$ & $\begin{array}{c}0.040 \\
(0.009)\end{array}$ & $\begin{array}{c}0.068 \\
(0.019)\end{array}$ & $\begin{array}{c}0.036 \\
(0.005)\end{array}$ & $\begin{array}{c}0.066 \\
(0.008)\end{array}$ \\
\hline Firm employs $<20$ & $\begin{array}{c}-0.022 \\
(0.033)\end{array}$ & $\begin{array}{c}-0.157 \\
(0.038)\end{array}$ & $\begin{array}{c}-0.104 \\
(0.026)\end{array}$ & $\begin{array}{c}-0.227 \\
(0.044)\end{array}$ & $\begin{array}{c}-0.070 \\
(0.013)\end{array}$ & $\begin{array}{c}-0.091 \\
(0.015)\end{array}$ \\
\hline $\begin{array}{c}\text { Firm employs } \\
200-1,999\end{array}$ & $\begin{array}{c}-0.011 \\
(0.023)\end{array}$ & $\begin{array}{c}0.090 \\
(0.046)\end{array}$ & $\begin{array}{l}-0.010 \\
(0.019)\end{array}$ & $\begin{array}{c}0.013 \\
(0.045)\end{array}$ & $\begin{array}{c}0.059 \\
(0.011)\end{array}$ & $\begin{array}{c}0.044 \\
(0.014)\end{array}$ \\
\hline $\begin{array}{l}\text { Firm employs } \\
\quad \geq 2,000\end{array}$ & $\begin{array}{c}0.035 \\
(0.024)\end{array}$ & $\begin{array}{c}0.161 \\
(0.050)\end{array}$ & $\begin{array}{c}0.022 \\
(0.022)\end{array}$ & $\begin{array}{c}0.140 \\
(0.053)\end{array}$ & $\begin{array}{c}0.103 \\
(0.010)\end{array}$ & $\begin{array}{c}0.082 \\
(0.015)\end{array}$ \\
\hline \multicolumn{7}{|l|}{ Summary statistic } \\
\hline Adjusted $R^{2}$ & 0.25 & 0.31 & 0.40 & 0.44 & 0.23 & 0.24 \\
\hline No. of observations & 992 & 528 & 1,039 & 564 & 12,599 & 7,452 \\
\hline Return to age (at 35) & $\begin{array}{c}0.0039 \\
(0.0012)\end{array}$ & $\begin{array}{c}0.0110 \\
(0.0020)\end{array}$ & $\begin{array}{c}0.0030 \\
(0.0011)\end{array}$ & $\begin{array}{c}0.0099 \\
(0.0024)\end{array}$ & $\begin{array}{c}0.0112 \\
(0.0006)\end{array}$ & $\begin{array}{c}0.0062 \\
(0.0007)\end{array}$ \\
\hline
\end{tabular}

Source: Authors' calculations based on data from the German Socio-Economic Panel.

a. The dependent variable is the hourly wage (expressed in logarithms). Each specification includes dummy variables for years and industry (results not reported). Samples are described in table 7. East Berlin is included with eastern Germany and West Berlin with western Germany. Standard errors are reported in parentheses.

b. Divided by 100 . 
analysis of between- and within-group inequality confirm the impression that the eastern wage structure has become very similar to that of the west, so that explanations for high unemployment must be sought elsewhere.

\section{Employment and the Wage Structure}

The convergence of the wage structure is occurring in the context of a large decline in employment in eastern Germany. The behavior of employment by skill should therefore be examined for further evidence on the appropriateness of the wage structure. It is possible that the wage structures should differ between east and west because of differing labor force endowments, possibly influenced also by differing participation rates. Hunt, using longitudinal data from the GSOEP, notes that the employment fall was largest for low-paid workers, whereas wage gains were the greatest for this group. ${ }^{78}$ This would appear to support the hypothesis that unions have caused unemployment by raising wages, particularly for the low skilled. However, the equivalent analysis for the west revealed that although wage gains were flat in initial earnings, employment losses were affected by initial earnings in the same way as in the east. As in other advanced market economies, employment in Germany appears much less stable for the low skilled.

It is more appropriate to examine changes in wages and employment by skill using the data as cross sections, since wage floors affect jobs rather than individuals. We seek evidence of wage floors using a technique close to that of David Card, Francis Kramarz, and Thomas Lemieux, and Krueger and Pischke. ${ }^{79}$ We use the same measure of skill for easterners as calculated above, based on predicted wages in the west. Wages are predicted this time for all individuals, not just those working. ${ }^{80}$ Skill groups are then defined using the skill cutoffs that result from dividing the individuals in the 1990 sample into twenty equally sized groups. ${ }^{81}$ For each skill group in any year, the employment rate and the average wage (for

78. Hunt (2001b).

79. Card, Kramarz, and Lemieux (1999); Krueger and Pischke (1998).

80. For this reason, the sample here is restricted to twenty-two- to fifty-four-year-olds. If eighteen- to twenty-one-year-olds are included, the two lowest skill cells are paid far less than the others and experience little employment change. This must be due to the large number of students in this age group.

81. Remember that skill is always based on 1980 s western coefficients, so that it does not drift as wages rise in the 1990s. 
Figure 4. Change in Wage and Employment for Easterners Working in Eastern Germany, 1990-99a

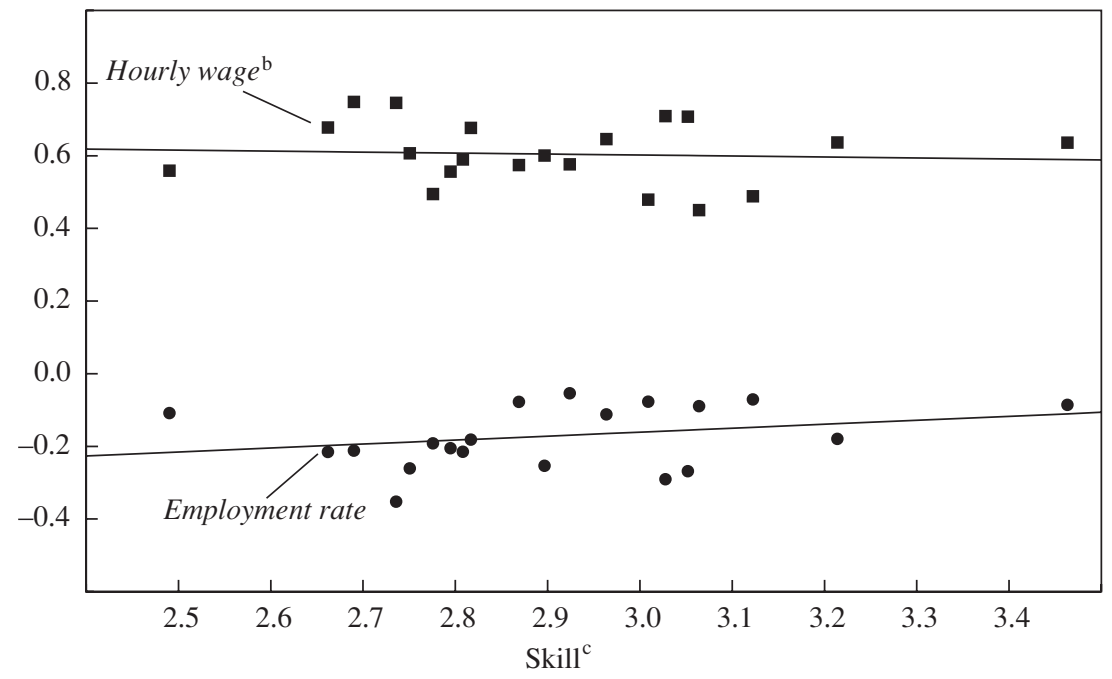

Source: Authors' calculations based on data from the German Socio-Economic Panel.

a. East Berlin is included with eastern Germany and West Berlin with western Germany.

b. Expressed in natural logarithms.

c. Wage (in logarithms) predicted for easterners using western skill coefficients.

those working) may be calculated. We plot the growth in the employment rate and the wage in the 1990-99 period for each skill group. We perform a parallel analysis for the west, using westerners' predicted wages in the west as the skill measure.

Figures 4 and 5 show the results for east and west, respectively, based on only basic controls in the regressions predicting skill (note the different scales). The graph for eastern workers appears somewhat consistent with the rising-wage-floor explanation of unemployment: the low skilled have the largest employment falls but appear to have slightly larger wage increases. The graph for western workers confirms the result of Krueger and Pischke, ${ }^{82}$ since employment growth is essentially flat in skill despite higher wage growth for the less skilled. The western data thus show that wages can rise for the low skilled with no apparent employment effects.

For the east, the relationship between wage growth and skill is sensitive to the definition of skill. In particular, if skill is predicted with tenure,

82. Krueger and Pischke (1998). 
Figure 5. Change in Wage and Employment for Westerners Working in Western Germany, 1990-99a

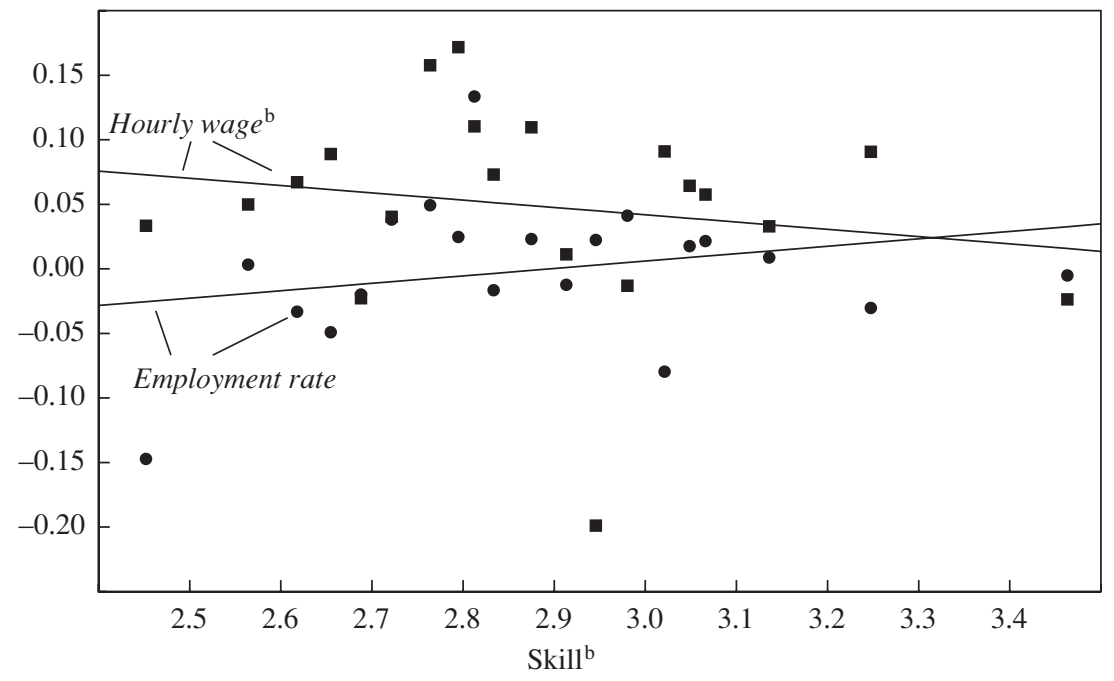

Source: Authors' calculations based on data from the German Socio-Economic Panel.

a. East Berlin is included with eastern Germany and West Berlin with western Germany.

b. Expressed in natural logarithms.

c. Wage (in logarithms) predicted for westerners using western skill coefficients.

firm size, industry, and part-time status among the controls, wage growth is higher for the high skilled (figure 6). (The graph for western workers is not sensitive to this change, and therefore the equivalent graph is not shown.) With these controls, only workers can be included in the sample, and hence employment growth is equal to zero for each cell and is not meaningful. This does not mean that the data are inconsistent with the rising-wage-floor story, since the wage floor could have made the growth in inequality less than it would have been, but neither do these graphs provide particularly strong support for the story.

\section{Employment and Wage Levels}

None of the above analyses were able to find conclusive evidence from relative wages or employment of distortionary effects of wage floors, be they union wages or welfare benefits. However, the tests are rather weak, given the absence of a clear expectation of what would have happened in the absence of these institutions. Chronically lower employment rates in 
Figure 6. Change in Hourly Wage for Easterners Working in Eastern Germany, Using Extended Controls, 1990-99a

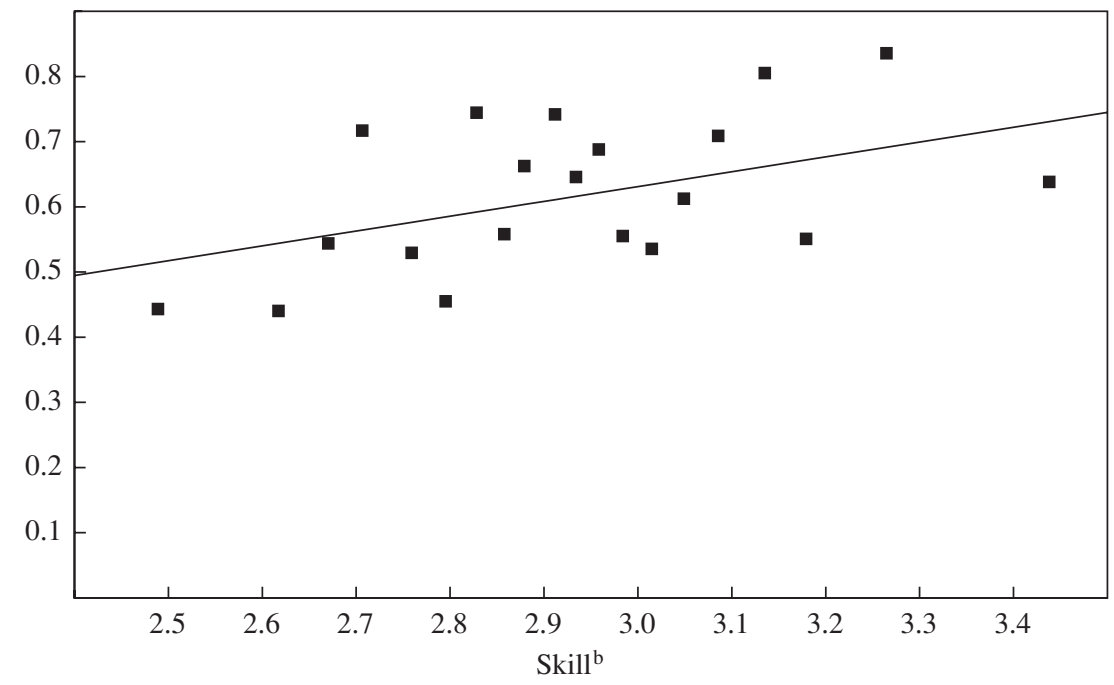

Source: Authors' calculations based on data from the German Socio-Economic Panel.

a. Expressed in natural logarithms. East Berlin is included with eastern Germany and West Berlin with western Germany.

b. Wage (in logarithms) predicted for easterners using western skill coefficients.

the east than in the west, as well as high unemployment rates in the east even when accounting for search and availability, point to a labor demand problem in the east. One possibility is that unions have pushed wages for all skill groups above the market-clearing wage, and that sharper employment falls for the less skilled are due to another labor demand factor common to market economies. Indeed, discussions of wage growth in the industrial relations crisis of 1993 were about the overall wage level, rather than about wages for the less skilled. Funke and Jörg Rahn demonstrate with firm-level data that eastern firms have more heterogeneous withinindustry TFP than do western firms, implying that imposing a uniform wage might have worse efficiency consequences in the east. ${ }^{83}$ Using data from another firm survey, however, Lutz Bellmann and Martin Brussig reject this argument. ${ }^{84}$

In sum, despite the difficulty of demonstrating it concretely, we are inclined to believe that wages have risen too fast and, as discussed earlier,

83. Funke and Rahn (forthcoming).

84. Bellmann and Brussig (1998). 
with the wrong distribution across firms and industries. That the overall wage level is too high and has caused unemployment is a commonly held view. Economists such as Akerlof and others, Klaus-Dietrich Bedau, Bellmann, and David Begg and Richard Portes have called for wage subsidies. ${ }^{85}$ Dennis Snower calls for profit-sharing schemes. ${ }^{86}$

Some insight into unemployment has been gained by considering the extremely high unemployment rate for women. The GSOEP search and availability-based measure indicates a 10 percent unemployment rate for men and a 15 percent rate for women. Hunt notes that lower rates of commuting to the west among married female workers with children have hurt the wage growth of female workers. ${ }^{87}$ Pressure to be at home in the evenings thus restricts job options and therefore must also raise the female unemployment rate. Hunt shows that a commonly advanced supply-side explanation for the greater employment declines for women, namely, the decline in the availability of child care, does not explain any of the malefemale gap in durations of employment or nonemployment spells. ${ }^{88}$ Some authors appear to suggest that the high eastern unemployment rate (as measured by registered unemployment) is an illusion created by women collecting benefits while out of the labor force. Were this the case, the GSOEP search and availability-based measure of unemployment would show similar rates for men and women, which it does not.

\section{Has Eastern Germany Become a Right-to-Work Region?}

If the overall level of wages is too high given the demand for labor, it is natural to look for labor market rigidities, and collective bargaining arrangements in particular, that might be keeping wages high. Yet a surprising side effect of the transformation of eastern Germany has been the collapse of the collective bargaining system imported from the west. This can explain the halt in wage convergence that began in 1995, evident from table 3. Part of this is simply the fact that promises were made but not kept; eastern German workers were not happy with trade union federation chief Dieter Schulte's promise of a high unemployment benefit as the result of

85. Akerlof and others (1991); Bedau (1996); Bellmann (1994); Begg and Portes (2001).

86. Snower (2001).

87. Hunt $(2000,2001 \mathrm{a})$.

88. Hunt (2001b, forthcoming). 
Table 16. Membership in Employers' Associations and Below-Union Wages in Eastern Germany, 1993-2000

Percent

\begin{tabular}{lcccc}
\hline Item & 1993 & 1995 & 1998 & 2000 \\
\hline $\begin{array}{l}\text { Share of all firms that are members of an } \\
\quad \text { employers' association }\end{array}$ & 36 & 27 & 21 & 16 \\
$\begin{array}{l}\text { Share of all employees employed by firms that } \\
\quad \text { are members of an employers' association }\end{array}$ & 76 & 64 & 45 & 34 \\
$\begin{array}{l}\text { Share of firms paying below the union wage } \\
\quad \text { for their industry and region }\end{array}$ & 35 & 33 & 41 & 40 \\
$\begin{array}{l}\text { Share of employees who are paid below the union } \\
\quad \text { wage for their industry and region }\end{array}$ & 12 & 16 & 28 & 29 \\
\hline
\end{tabular}

Source: DIW, Wochenbericht, various issues.

a. East Berlin is included with eastern Germany and West Berlin with western Germany.

the rapid increase of wages in the early years. ${ }^{89}$ The punishment for the rise in unemployment and incomplete wage convergence was a massive decline in union membership in the east, from just under 50 percent of workers in 1991 to about 22 percent in 2000, compared with a drop from 25 percent to 18 percent in the west over the same period.

More decisive for coverage of collective agreements than the decline in membership, however, is the fall in membership in the employers' associations, which function as bargaining intermediaries for large industrial collective wage agreements; low and declining membership vitiates the credibility of wage agreements and of the collective bargaining system itself. Table 16 documents the sharp decline in the share of firms that are party to collective agreements and, more important, the rising fraction of workers not covered by such agreements. Even those firms that remain-onethird of all eastern German enterprises by most guesses-have the option of invoking an opt-out clause (Öffnungsklausel), although this was originally conceived in the west as an escape valve for rare and dramatic cases.

This decline in influence has resulted in an increased readiness on the part of workers and works councils to engage in U.S.-style plant-level "concession bargaining," in which workers accept wages below minimum (industry-wide) contract-determined levels in order to save their enterprises from bankruptcy. Under western German collective bargaining conventions, this development would have been unthinkable, as members of

89. Akerlof and others (1991); Burda and Funke (1995). 
employers' federations are joint signatories to collective wage agreements and thus bound to pay at least the minimum wages specified in the contract. Yet an increasing number of firms, no longer able to pay wages decided on in the west, have implicitly or explicitly defected from collective bargaining agreements and have abandoned their employers' associations in the east, leaving open the possibility of enterprise-level bargaining..$^{90}$ Susanne Kohaut and Claus Schnabel estimate that this type of bargaining is becoming more and more important over time. ${ }^{91}$ The result has been a schism in collective bargaining between east and west and the establishment of a right-to-work region similar to that in the southern United States in the 1970s. ${ }^{92}$

\section{The Role of Migration in German Integration: An Empirical Analysis}

In a free labor market, workers can vote with their feet. Households can escape unsatisfactory conditions by simply moving to other labor markets where jobs are more plentiful or pay is better. Thus migration is an essential component of the integration process. In the absence of mobility costs and externalities, it is unequivocally more efficient to allow mobility, whether in the form of commuting or of migration. In more general settings one must weigh the cost of sending capital to the capital-poor region against that of sending workers to the capital-rich region. How much mobility can be observed between the poor east and the rich west? Does it respond to wages only, or also to differences in the unemployment rate?

In this section we evaluate the extent of labor mobility in eastern Germany. We present evidence based on a sample of adults from the GSOEP data, and on official data from the German Federal Statistical Office on gross migration flows to and from all the states of Germany for 1991-99. From the Bundesamt für Bauwesen und Raumordnung we have migra-

90. See Schnabel (1999). This situation can be changed only to the extent that the minister of labor declares a contract binding on all firms and workers in a particular sector, should he or she deem this to be in the public interest. The possibility of such an action seems remote at present.

91. Kohaut and Schnabel (1999).

92. The Industrial Investment Council, founded to promote foreign direct investment in the east, has recently touted labor market flexibility as a central advantage of the region over western European locations. 
Figure 7. Migration between Eastern and Western Germany, 1957-99a

Thousands

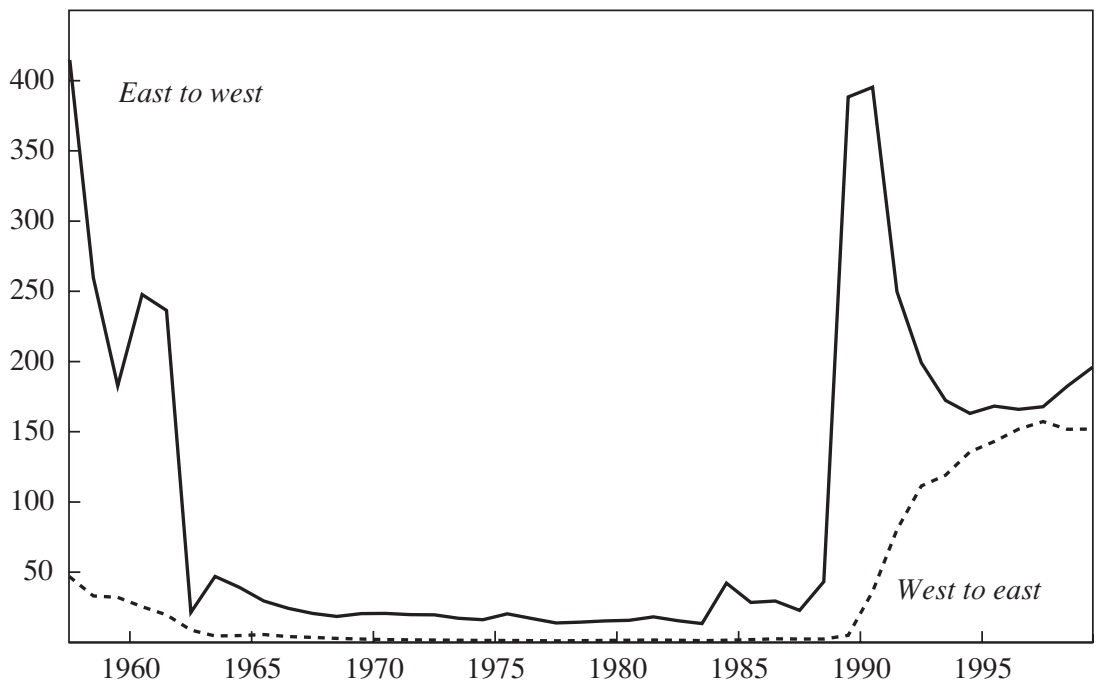

Source: German Federal Statistical Office.

a. East Berlin is included with eastern Germany and West Berlin with western Germany.

tion data by age for 1991-94 and 1997, based on flows among ninety-five smaller regions (Raumordnungsregionen), and from the state statistical offices we have all flows by age to and from Saxony and MecklenburgWestern Pomerania for 1991-99. Because definitions are slightly inconsistent across years for the city-states Hamburg, Bremen, and Berlin in the data by age, for regressions by age we aggregate Berlin and Brandenburg into one state, and Schleswig-Holstein, Hamburg, Lower Saxony, and Bremen into another. Variables for these aggregates are obtained by weighting or summing those of the component states, as appropriate.

\section{The Scale of East-West Migration}

Eastern Germans have had access to the western German labor market ever since Hungary began allowing citizens of East Germany to cross into Austria in August 1989. This access became significantly less costly in November $1989 .{ }^{93}$ Figure 7 gives a long-term perspective on flows between

93. Grundmann (1998) gives more detail on the events of 1989-90. 
east and west from 1957 to 1999 . The outflows in 1989 and 1990 each represent 2.5 percent of the East German population at the time and were of the same magnitude as the outflows in the 1950s that led first to a ban on emigration and then to the construction of the Wall. Emigration from the east fell quickly after 1990, to almost zero on net, but has risen once again in recent years. The figure underlines that at least some proportion of heterogeneous labor can move instantaneously, which is less true of capital.

The outflow of people to the west has contributed to a remarkable decline-by 8.7 percent between 1989 and 1999—in the eastern German population, with a significant drop in the birth rate being the other main contributor. Table 17 decomposes the population change into three components: the excess of deaths over births, net emigration to the west, and net immigration from abroad. Excess deaths have reduced the population by 4.7 percent, and net emigration to the west by 7.2 percent. Net immigration from abroad has offset the population decline slightly, contributing 2.5 percent.

Since the mid-1990s the eastern states have been accepting ethnic German immigrants (Aussiedler) from Russia and from central and eastern Europe, who are allocated among the states on arrival. These immigrants have shown a tendency to move to the west soon after being officially

Table 17. Decomposition of Population Decline in Eastern Germany, 1989-99a

\begin{tabular}{lcc}
\hline Item & Millions & $\begin{array}{c}\text { Percent of 1988 } \\
\text { population }\end{array}$ \\
\hline Registered population, 1988 & 16.675 & $\ldots$ \\
Registered population, 1999 & 15.217 & 91.3 \\
Change & -1.458 & -8.7 \\
Births, 1989-99 & 1.220 & 7.3 \\
Deaths, 1989-99 & -1.998 & -12.0 \\
Change & -0.779 & -4.7 \\
Moved to western Germany, 1989-99 & -2.448 & -14.7 \\
Moved from western Germany, 1989-99 & 1.244 & 7.5 \\
Change & -1.204 & -7.2 \\
Net migration from abroad, 1989-99c & 0.422 & 2.5 \\
Calculated population, 1999 & 15.114 & 90.6 \\
Difference between registered and & & \\
calculated population & 0.103 & 0.6 \\
\hline Sources: Statistical Yearbook of the German Democratic Republic, 1989; and German Federal Statistical Office data. \\
a. East Berlin is included with eastern Germany and West Berlin with western Germany. \\
b. End-of-year value. \\
c. Data on outside migration are not available for 1990.
\end{tabular}


Figure 8. Net Emigration Rates, by Region and Age, 1991-97
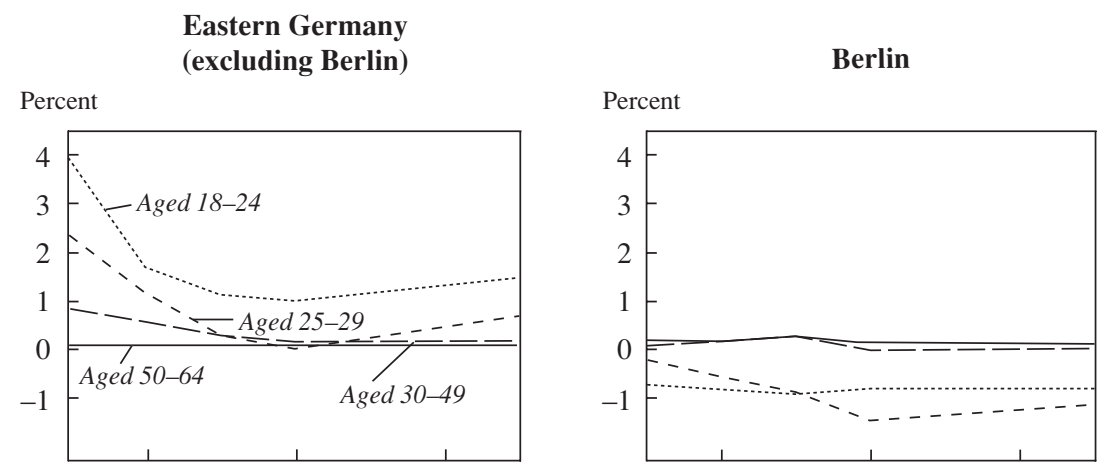

Baden-Württemberg and Bavaria
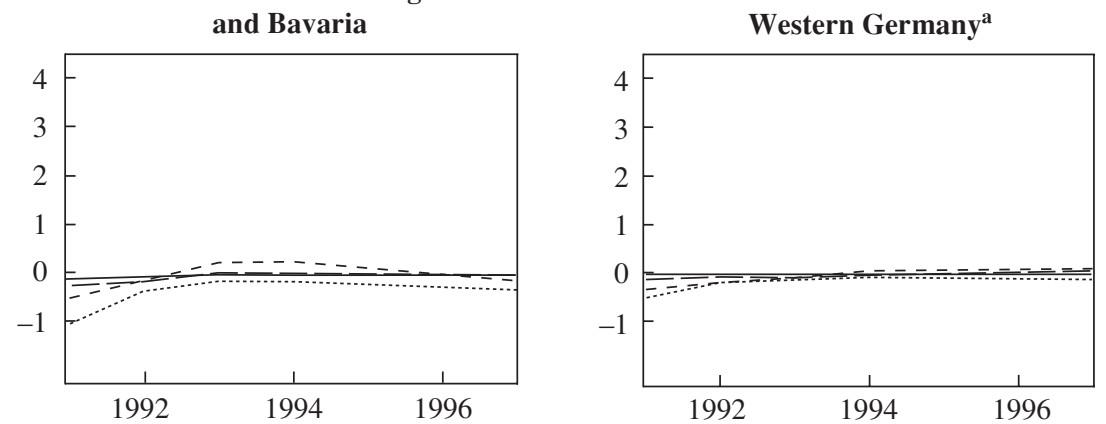

Source: Unpublished data from Bundesamt für Bauwesen und Raumordnung. a. Excludes Baden-Württemberg and Bavaria.

settled in the east, and have hence contributed to east-west flows as well as to the inflows from abroad. The number of Aussiedler officially established in the east through 1998 (assuming equal shares in East and West Berlin) represented 1.9 percent of the 1989 eastern population. ${ }^{94}$

Consistent with the theory of migration as human capital investment, ${ }^{95}$ the young are much more likely to move than older people. Figure 8 shows net annual emigration rates by age for each of four large areas: eastern Germany excluding Berlin, Berlin (which is aggregated with its suburbs into a single region), Bavaria and Baden-Württemberg, and the rest of

94. Dietz (1999).

95. Sjaastad (1962). 
Table 18. Composition of Easterners Working in Western Germany, 1990-99a

Percent of total

\begin{tabular}{lccc}
\hline & \multicolumn{3}{c}{ Year left eastern Germany } \\
\cline { 2 - 4 } Type & $1990-92$ & $1993-99$ & $1990-99$ \\
\hline Commuters & 49 & 39 & 43 \\
Transferred commuters & & 25 & 19 \\
Emigrants & 11 & 28 & 30 \\
Transferred emigrants $^{\mathrm{b}}$ & 33 & 8 & 7 \\
\hline
\end{tabular}

Source: Authors' calculations based on data from the German Socio-Economic Panel.

a. The sample consists of 385 persons aged eighteen or over. East Berlin is included with eastern Germany and West Berlin with western Germany. Columns may not sum to 100 because of rounding.

b. "Transferred" refers to those who emigrated or who began commuting to western Germany but report working for the same employer as before.

western Germany. Net annual emigration of eighteen- to twenty-four-yearolds from the east excluding Berlin has been above 1 percent throughout the transition. Net emigration of twenty-five- to twenty-nine-year-olds dipped to zero in 1993-94 but then began rising again. Greater Berlin is the only other area with similarly sustained high net flows: in this case high net immigration of eighteen- to twenty-four- and twenty-five- to twenty-nine-year-olds. A complete picture must include flows to and from abroad, but the numbers in table 17 show that they cannot be large enough to reverse the general picture of high net emigration of young people from the east. The high net emigration rates in the east are due to high gross emigration and normal gross immigration; the net flows disguise higher gross flows for Bavaria and Baden-Württemberg than for the rest of the west.

\section{Characteristics of Migration and Commuting}

Migration is only one aspect of labor mobility between east and west. The existence of the enclave of West Berlin and the long border between the two Germanys meant that commuting has been a feasible substitute for emigration for many easterners. Table 18 uses the GSOEP data to show for various periods the relative importance of emigrants and commuters. These data record a considerable number of movers, particularly commuters, who emigrate or begin to commute but report staying with the same employer. ${ }^{96}$ We refer to these as "transferred" commuters or emigrants. Over the whole period 1990-99, 62 percent of people who

96. Pischke, Staat, and Vögele (1994) also observe this in the Arbeitsmarktmonitor data for 1991. 
moved either their home or their workplace to the west were commuters. Thirty-one percent of commuters (19 percent of all movers) were transferred, whereas 19 percent of emigrants ( 7 percent of all movers) were transferred, and the share of transferred commuters rose over time.

Commuters tend to work in the west for a less extended period than emigrants live in the west, however, and they account for only 35 percent of mover time in the west (total years spent in the west by emigrants and commuters combined). In the GSOEP data, the number of commuters who stop working in the west is 64 percent of the number of commuters who start working in the west in the same period (1990-99). If commuters who ultimately emigrate are included in the sample, the proportion of commuters who cease commuting is 73 percent. Calculations that we performed (but that are not reported in detail here) indicate that transferred commuters stay a shorter time in the west than do ordinary commuters, suggesting that many have been sent by their firm temporarily for training or experience in the west.

The number of easterners moving back from the west is 29 percent of the number emigrating to the west. This number is sensitive to the use of the sample weights: the unweighted ratio is 18 percent. The unweighted ratio is likely to be an underestimate, however, since movers are more likely to be lost by the survey than stayers, and double movers even more likely. There is thus substantial return migration of 18 to 29 percent, but most emigrants have remained in the west.

Consistent with the theory developed in the previous section, we find strong evidence of sizable wage gains by migrants. Table 19 shows real wage growth (the ratio of wages in two consecutive years) for stayers and for all mover types among eastern Germans. Commuters, who benefited from the low consumption prices in the east, doubled their monthly wages by working in the west. This compares with average wage growth of 14 percent for stayers. Transferred commuters gained much less, 31 percent on average, because they were earning western wages to start with. Emigrants gained 83 percent on average. (This estimate is sensitive to weighting. Their unweighted wage growth is 51 percent.) As a check, the wage growth for those who stop commuting or who return to live in the east is also reported, despite the small sample. Returning commuters experience wage growth of only 2 percent (again compared with 14 percent for stayers), whereas returning emigrants lose almost a third of their wage. Wage growth slowed considerably in the latter part of the decade. 
Table 19. Real Wages of Easterners Working in Western Germany and Returnees, 1990-99a

Ratio of current wage to previous year's wage

\begin{tabular}{lccc}
\hline & \multicolumn{3}{c}{ Year left eastern Germany } \\
\cline { 2 - 4 } Type & $1990-92$ & $1993-99$ & $1990-99$ \\
\hline Stayers & 1.23 & 1.09 & 1.14 \\
& $(0.01)$ & $(0.01)$ & $(0.01)$ \\
Commuters & 2.44 & 1.41 & 2.11 \\
& $(0.06)$ & $(0.07)$ & $(0.04)$ \\
Transferred commuters ${ }^{\mathrm{b}}$ & 1.52 & 1.24 & 1.31 \\
& $(0.11)$ & $(0.05)$ & $(0.05)$ \\
Emigrants & 1.85 & 1.81 & 1.83 \\
& $(0.11)$ & $(0.10)$ & $(0.08)$ \\
Transferred emigrants & 1.08 & 1.47 & 1.32 \\
& $(0.14)$ & $(0.10)$ & $(0.08)$ \\
Returning commuters & 0.88 & 1.07 & 1.02 \\
& $(0.09)$ & $(0.05)$ & $(0.04)$ \\
Returning emigrants & n.a. & 0.68 & 0.68 \\
& & $(0.12)$ & $(0.13)$ \\
\hline
\end{tabular}

Source: Authors' calculations based on data from the German Socio-Economic Panel.

a. Change computed only for individuals aged eighteen or older with nonzero wages in both years. East Berlin is included with eastern Germany and West Berlin with western Germany. Standard errors are reported in parentheses.

b. "Transferred" refers to those who emigrated or who began commuting to western Germany but report working for the same employer.

\section{Determinants of Migration}

Up until the parliamentary elections in East Germany in March 1990, the main motivation for emigration was political, with family reunification second in importance. ${ }^{97}$ At that point it became clear that reunification would come rapidly, and economic reasons became dominant. Any analysis with the GSOEP data begins shortly after this change, whereas any analysis with state-level data from government sources begins in 1991, when emigration was still high but past its peak.

Hunt, using the GSOEP to follow individuals, conducted a detailed analysis of which easterners emigrate and which commute. ${ }^{98}$ Three common types of mover are young people moving to study in the west, tertiary education graduates who move immediately after graduation, and people who have recently been laid off. The updated GSOEP data show that movers of all kinds are on average eleven to fifteen years younger than stayers, and that 30 percent of commuters and 15 percent of emigrants

97. See the references to surveys of emigrants in Grundmann (1998).

98. Hunt (2000). 
have recently been laid off, compared with 6 percent of stayers. People living in a county on the border with the west tend to commute rather than emigrate. East Berliners are an exception, since they both commute and migrate more than nonborder residents. People living around West Berlin make up 32 percent of commuters and 35 percent of transferred commuters (in years where they can be identified, those commuting once a week make up one-third of commuters). ${ }^{99}$

The data on individuals cannot be used to distinguish factors at home that push emigrants out from factors in the destination that attract workers. For this it is necessary to use the aggregate data on gross flows between states, and variables describing all the states. We present results here that update the analysis by Hunt to include the recent increase in east-west migration, ${ }^{100}$ and we extend it by comparing age groups.

The econometric approach we adopt is to use migration flows within the west as a point of comparison for the magnitude of east-to-west flows. We wish to see whether wage and unemployment variables can explain how east-to-west flows diverge from within-west flows. We use a fixedeffects model with two dummy variables for each pair of states (one for each direction):

$$
\begin{aligned}
\ln M_{s d t}= & \alpha_{s d}+\beta_{0} \ln w_{s t}+\beta_{1} \ln w_{d t}+\beta_{2} \ln U_{s t}+\beta_{3} \ln U_{d t} \\
& +\beta_{4} E W_{s d} \times t+\beta_{5} E W_{s d} \times t^{2}+\beta_{6} W E_{s d} \times t \\
& +\beta_{7} E E_{s d} \times t+\Sigma_{j} \gamma_{j} T_{j}+\varepsilon_{s d t},
\end{aligned}
$$

where $M$ is the number of individuals moving from source state $s$ to destination state $d, w$ is the wage, $U$ is the number of unemployed, $T_{j}$ are year dummies, and $\alpha_{s d}$ are the fixed effects. The specification allows a quadratic relationship in time in east-to-west flows $(E W)$ relative to withinwest flows, and linear trends in west-to-east flows $(W E)$ and within-east flows $(E E)$. Berlin is treated as a special case, neither east nor west; to eliminate clutter in equation 2 , we suppress mention of the trends for flows between the east and Berlin and between the west and Berlin ( $E B$, $B E, W B, B W)$.

99. Other papers using GSOEP data to examine emigration include Burda (1993), Burda and others (1998), and Schwarze (1996).

100. Hunt (2000). 
Table 20. Explaining Migration Patterns with Wages and Unemployment, 1991-99a

\begin{tabular}{|c|c|c|c|c|c|}
\hline \multirow[b]{2}{*}{ Independent variable } & \multicolumn{3}{|c|}{ Full sample } & \multirow{2}{*}{$\frac{\text { Sample Ac }}{20-4}$} & \multirow{2}{*}{$\frac{\text { Sample } B^{\mathrm{d}}}{20-5}$} \\
\hline & $20-1$ & $20-2$ & $20-3$ & & \\
\hline$E W \times$ years since unification ${ }^{\mathrm{e}}$ & $\begin{array}{c}-0.204 \\
(0.014)\end{array}$ & $\begin{array}{c}-0.091 \\
(0.023)\end{array}$ & $\begin{array}{l}-0.080 \\
(0.023)\end{array}$ & $\begin{array}{l}-0.081 \\
(0.027)\end{array}$ & $\begin{array}{l}-0.098 \\
(0.033)\end{array}$ \\
\hline $\begin{array}{l}E W \times \text { years since unification } \\
\quad \text { squared }\left(t^{2}\right)\end{array}$ & $\begin{array}{l}0.023 \\
(0.002)\end{array}$ & $\begin{array}{c}0.012 \\
(0.002)\end{array}$ & $\begin{array}{c}0.011 \\
(0.002)\end{array}$ & $\begin{array}{c}0.011 \\
(0.003)\end{array}$ & $\begin{array}{c}0.016 \\
(0.003)\end{array}$ \\
\hline Destination hourly wage & & $\begin{array}{c}1.811 \\
(0.220)\end{array}$ & $\begin{array}{l}1.658 \\
(0.234)\end{array}$ & $\begin{array}{c}1.704 \\
(0.289)\end{array}$ & $\begin{array}{l}0.968 \\
(0.333)\end{array}$ \\
\hline Source hourly wage & & $\begin{array}{l}-1.077 \\
(0.258)\end{array}$ & $\begin{array}{l}-1.146 \\
(0.263)\end{array}$ & $\begin{array}{l}-1.836 \\
(0.271)\end{array}$ & $\begin{array}{l}-2.319 \\
(0.311)\end{array}$ \\
\hline $\begin{array}{l}\text { Unemployed in destination } \\
\text { state }\end{array}$ & & & $\begin{array}{l}-0.195 \\
(0.059)\end{array}$ & $\begin{array}{c}-0.237 \\
(0.074)\end{array}$ & $\begin{array}{l}-0.205 \\
(0.077)\end{array}$ \\
\hline Unemployed in source state & & & $\begin{array}{c}0.009 \\
(0.054)\end{array}$ & $\begin{array}{l}0.084 \\
(0.070)\end{array}$ & $\begin{array}{l}-0.041 \\
(0.076)\end{array}$ \\
\hline \multicolumn{6}{|l|}{ Calculated value } \\
\hline Slope of $E W \times t^{2}$ in 1992 & $\begin{array}{l}-0.157 \\
(0.011)\end{array}$ & $\begin{array}{l}-0.067 \\
(0.019)\end{array}$ & $\begin{array}{c}-0.058 \\
(0.019)\end{array}$ & $\begin{array}{l}-0.059 \\
(0.022)\end{array}$ & $\begin{array}{l}-0.067 \\
(0.026)\end{array}$ \\
\hline Slope of $E W \times t^{2}$ in 1998 & $\begin{array}{c}0.119 \\
(0.010)\end{array}$ & $\begin{array}{c}0.076 \\
(0.010)\end{array}$ & $\begin{array}{c}0.071 \\
(0.010)\end{array}$ & $\begin{array}{c}0.072 \\
(0.021)\end{array}$ & $\begin{array}{c}0.121 \\
(0.020)\end{array}$ \\
\hline \multicolumn{6}{|l|}{ Summary statistic } \\
\hline$R^{2}$ & 0.24 & 0.28 & 0.28 & 0.48 & 0.41 \\
\hline No. of observations & 2,130 & 2,130 & 2,130 & 828 & 1,050 \\
\hline
\end{tabular}

Source: Authors' calculations based on data from the German Federal Statistical Office and Bundesamt für Bauwesen und Raumordnung.

a. The dependent variable is the number of internal migrants (expressed in logarithms). Wage data for Bremen are not available for 1992. Migration flows, wages, and number of unemployed are expressed in logarithms. All specifications include fixed effects for each state pair in each direction, year dummies, and terms interacting a time trend and migration direction dummies (all not reported). Robust standard errors are reported in parentheses.

b. Regressions use flow data for all states and city-states individually.

c. Aggregates flow data for Berlin and Brandenburg into one state, and Bremen, Hamburg, Lower Saxony, and SchleswigHolstein into another.

d. As in the full sample but drops observations for city-states for 1991-93.

e. $E W$ is a dummy variable indicating a flow of migrants from east to west.

We do not attempt to deal with endogeneity issues. If the path of wages (at least for 1991-93) is viewed as being set exogenously by the labor unions, who chose that wage path in 1990-91, the main endogeneity problems are composition effects and unemployment. Any solutions would have to depend on lagged independent variables, which, given the forwardlooking nature of the problem, we feel would be inappropriate. The endogeneity should bias the coefficients on the economic variables toward zero, and thus make them less able to explain the east-to-west pattern.

The results of the estimation for all ages together are presented in table 20. We present the coefficients on the most important variables, 
and at the bottom of the table we calculate the slope, in 1992 and 1998, of the quadratic capturing east-to-west flows. The specification reported in column 20-1 includes no economic control variables. In 1992 east-to-west flows were falling at a rate of $15.7 \log$ points ( 14.5 percent) a year, whereas in 1998 they were rising at a rate of 11.9 percent a year. In the regression in column 20-2 we add as independent variables the logarithms of the source and the destination wages. Wage differentials explain a little more than half the 1992 slope (the remaining, unexplained downward slope is 6.7 percent) and less than half the 1998 slope. Adding source and destination unemployment in column 20-3 helps only a little in explaining more of the trend. The puzzling insignificant coefficient on source unemployment replicates the results of Hunt and several other studies. ${ }^{101}$

In the remaining two columns of table 20, we run the same regression on two samples with fewer observations, which we will then use for regressions by age. In the first sample we combine some states as described above (sample A). In the second sample we instead omit observations from the city-states in the early years when the state boundaries are inconsistently defined; this leads to more observations, but fewer in the more interesting early years (sample B). The results for sample A are more similar to those for the full sample, and so we present results from this sample for the regressions by age, although the results for sample B are similar. The main difference between the sample A and the full-sample results is the larger coefficient on the source wage for sample A.

Table 21 presents results of the same regression for three subsamples grouped by age: young, prime-aged, and older individuals. The younger the group, the more sensitive it is to the source wage. There are no statistically significant differences by age in the response to the destination wage or destination unemployment. Older workers respond statistically significantly in the expected direction to source unemployment: the main source of the puzzling coefficient in the table for all ages comes from the young, for whom source unemployment has a negative sign but is insignificant (the result is significant for sample B, not shown). The results for prime-aged workers are in between.

101. Hunt (2000); other studies include Lundborg (1991) for Sweden, Pissarides and Wadsworth (1989) for the United Kingdom, and Bentivogli and Pagano (1999) for the euro zone. 
Table 21. Explaining Migration Patterns with Wages and Unemployment, by Age of Migrant, 1991-99a

\begin{tabular}{|c|c|c|c|c|c|c|}
\hline \multirow[b]{2}{*}{ Independent variable } & \multicolumn{2}{|c|}{ Aged 18-24 } & \multicolumn{2}{|c|}{ Aged 25-49 } & \multicolumn{2}{|c|}{ Aged 50-64 } \\
\hline & $21-1$ & $21-2$ & $21-3$ & $21-4$ & $21-5$ & $21-6$ \\
\hline $\begin{array}{c}E W \times \text { years since } \\
\text { unification }\end{array}$ & $\begin{array}{c}-0.255 \\
(0.023)\end{array}$ & $\begin{array}{l}-0.027 \\
(0.033)\end{array}$ & $\begin{array}{l}-0.275 \\
(0.018)\end{array}$ & $\begin{array}{c}-0.104 \\
(0.029)\end{array}$ & $\begin{array}{c}-0.144 \\
(0.023)\end{array}$ & $\begin{array}{l}-0.025 \\
(0.037)\end{array}$ \\
\hline $\begin{array}{l}E W \times \text { years since } \\
\quad \text { unification squared }\left(t^{2}\right)\end{array}$ & $\begin{array}{c}0.031 \\
(0.003)\end{array}$ & $\begin{array}{c}0.009 \\
(0.004)\end{array}$ & $\begin{array}{c}0.033 \\
(0.002)\end{array}$ & $\begin{array}{c}0.015 \\
(0.003)\end{array}$ & $\begin{array}{c}0.014 \\
(0.003)\end{array}$ & $\begin{array}{l}-0.000 \\
(0.004)\end{array}$ \\
\hline Destination hourly wage & & $\begin{array}{c}1.706 \\
(0.355)\end{array}$ & & $\begin{array}{l}1.226 \\
(0.285)\end{array}$ & & $\begin{array}{l}1.322 \\
(0.417)\end{array}$ \\
\hline Source hourly wage & & $\begin{array}{l}-2.686 \\
(0.334)\end{array}$ & & $\begin{array}{l}-1.576 \\
(0.268)\end{array}$ & & $\begin{array}{l}-0.616 \\
(0.392)\end{array}$ \\
\hline $\begin{array}{l}\text { Unemployed in } \\
\text { destination state }\end{array}$ & & $\begin{array}{c}-0.218 \\
(0.091)\end{array}$ & & $\begin{array}{l}-0.308 \\
(0.073)\end{array}$ & & $\begin{array}{l}-0.170 \\
(0.106)\end{array}$ \\
\hline $\begin{array}{l}\text { Unemployed in source } \\
\text { state }\end{array}$ & & $\begin{array}{c}-0.055 \\
(0.086)\end{array}$ & & $\begin{array}{c}0.135 \\
(0.069)\end{array}$ & & $\begin{array}{c}0.269 \\
(0.102)\end{array}$ \\
\hline \multicolumn{7}{|l|}{ Calculated value } \\
\hline Slope of $E W \times t^{2}$ in 1992 & $\begin{array}{c}-0.192 \\
(0.017)\end{array}$ & $\begin{array}{l}-0.010 \\
(0.026)\end{array}$ & $\begin{array}{l}-0.209 \\
(0.013)\end{array}$ & $\begin{array}{c}-0.074 \\
(0.021)\end{array}$ & $\begin{array}{c}-0.116 \\
(0.018)\end{array}$ & $\begin{array}{l}-0.024 \\
(0.031)\end{array}$ \\
\hline Slope of $E W \times t^{2}$ in 1998 & $\begin{array}{c}0.185 \\
(0.021)\end{array}$ & $\begin{array}{c}0.092 \\
(0.027)\end{array}$ & $\begin{array}{c}0.191 \\
(0.017)\end{array}$ & $\begin{array}{c}0.111 \\
(0.021)\end{array}$ & $\begin{array}{c}0.050 \\
(0.024)\end{array}$ & $\begin{array}{l}-0.020 \\
(0.031)\end{array}$ \\
\hline \multicolumn{7}{|l|}{ Summary statistic } \\
\hline$R^{2}$ & 0.49 & 0.55 & 0.36 & 0.43 & 0.37 & 0.39 \\
\hline No. of observations & 828 & 828 & 828 & 828 & 828 & 828 \\
\hline
\end{tabular}

Source: Authors' calculations based on data from the German Federal Statistical Office and Bundesamt für Bauwesen und Raumordnung.

a. The dependent variable is the number of internal migrants (expressed in logarithms). The sample is sample A as described in table 20. Wage data for Bremen are not available for 1992. Migration flows, wages, and number of unemployed are expressed in logarithms. All specifications include fixed effects for each state pair in each direction, year dummies, and terms interacting a time trend and migration direction dummies (all not reported). Robust standard errors are reported in parentheses.

b. $E W$ is a dummy variable indicating a flow of migrants from east to west.

Wages and unemployment explain the whole 1992 trend for young people, two-thirds of the trend for prime-aged people, and most of the smaller trend for older people. Results not presented here show that the explanatory power comes entirely from wages, as in table 20. One could summarize these results by saying that the labor unions were correct in expecting that high wages would keep people in the east. These results clarify the mechanism for this wage effect, first noted by Hunt ${ }^{102}$; they also explain the discrepancy between the individual-level results showing that laid-off workers emigrate and the aggregate results showing that source unemployment is not a push factor. Source unemployment apparently only

102. Hunt (2000). 
affects those experiencing a layoff; this is mainly an age group older than the eighteen- to twenty-four-year-olds who are most likely to move, since the young are typically moving west to study or take a first job. An unreported tabulation shows that the average emigrant who has been laid off is five years older than the average emigrant who has not been laid off (although the sample is small). Thus, in the data on individuals, laid-off people emigrate, but the coefficient in the aggregate data is dominated by the high-emigration young group, which does not respond to layoffs. The high wages may have caused layoffs among older workers early in the transition but apparently kept young students at home in the hope of later getting a high-paying job. Thus, on balance, high wages in the east reduced emigration.

Wages and unemployment are less successful in explaining the 1998 rise in immigration, accounting in the various specifications and samples for at most half the rise, and often less. In this case, however, the explanatory power of wages and that of unemployment are much more equal. The failure of the contemporaneous variables to explain fully the 1998 rise in emigration to the west does not surprise us. A plausible interpretation of the upturn is that it reflects a realization that wage convergence will not resume in the near future. The expectation of future relative wages has been adjusted downward in the mean, and the variance of future convergence scenarios has fallen, reducing the option value of waiting, that is, of postponing migration. ${ }^{103}$

All regressions were rerun using the weekly rather than the hourly wage, hence capturing differences in weekly hours. Weekly wages are more successful in explaining both the 1992 slope and the 1998 slope; for example, in the regressions for all ages the unexplained 1992 slope is only -0.016 , and the unexplained 1998 slope is 0.060 .

\section{Conclusions and Policy Recommendations}

The transition in eastern Germany may be viewed as successful along many dimensions. Convergence in GDP per capita has exceeded the

103. See Bauer (1995), Burda (1995), and O'Connell (1997) for models that apply the notion of the option value of waiting to the migration decision. 
expectations of most economists, convergence in consumption is even more impressive, and all institutions of the west have been successfully transferred, conferring social stability and aiding the economy. However, the gap between consumption and GDP per capita means that the east remains dependent on transfers from the west, the labor market is still in disarray, GDP convergence has halted, and TFP growth has slumped to below the western level and in some states has even turned negative.

Some indicators give grounds for optimism that convergence may soon resume. The almost full convergence of the wage structure, which continued in the last two years for which data were available (1997-99), is an encouraging sign that wages are becoming more flexible. This should allow wages across firms and industries to be set more appropriately than in the past, which should allow more sectoral restructuring, in turn boosting employment and efficiency. This is confirmed by the current expansion of activity other than construction, offsetting the sharp decline in that sector. Once the construction decline is complete, the greater wage flexibility should boost employment. Signs that wages are falling overall could also presage a rise in employment. Although we believe that wages would have risen quickly soon after reunification because of westward migration and generous social benefits, we argue that labor unions caused them to rise still further. The subsequent weakening of the labor unions in the east has allowed wages to become more flexible, and higher employment should be one of the medium-term benefits. A recession in western Germany would naturally postpone these gains.

Our findings suggest some recommendations for policy action to raise eastern productivity. We find that, controlling for worker characteristics, firm size, and industry (but not capital), the east-west productivity gap is approximately constant across skill levels. This leads us to search for skillneutral explanations for the productivity gap, such as inferior infrastructure. Indeed, recent data show that although some types of infrastructure are at least as good in the east as in the west, in other areas the east still lags behind. Given the public good nature of infrastructure, we recommend continued investment in this area. Another intriguing factor that could reduce productivity at all skill levels is a deficiency of business skills. We provide no original evidence on this but believe it warrants further investigation and possibly policy action. Credit constraints on firms could also play a role. This notwithstanding, we recommend that the 
reduction in subsidies to capital continue, and that distortions that favor certain sectors for investment or certain types of investor be phased out or eliminated. The nature of past subsidies has led to overinvestment in structures and underinvestment in equipment. ${ }^{104}$

We find that those who emigrate tend to be better educated and possibly better workers in unobservable ways than stayers, which may reduce TFP in the east. These observations would warrant policy action only if one cared more about the east than about Germany as a whole, since migration should increase overall efficiency. Nevertheless, the ongoing efforts to make the eastern universities more attractive to students could eventually raise eastern TFP, since students are an important category of emigrant.

In addition to the expectation that more flexibility in the industrial relations system will help unemployment on the demand side, we offer some recommendations that address other inefficiencies and should allow the east to use its labor more efficiently. The first is that public training programs be scaled back significantly. As our analysis has shown, it is unlikely that the source of the east's difficulties is an unskilled labor force. Furthermore, in a series of careful papers, Michael Lechner demonstrates that these programs have little detectable benefit. ${ }^{105}$ And despite eastern Germany's high unemployment, we are also uneasy about the role of public works jobs, despite a cautiously optimistic evaluation of their impact on individuals by Martin Eichler and Lechner. ${ }^{106}$ The government feels obliged to offer 90 percent of the union wage on these jobs, even though many private firms pay less than 90 percent of the union wage for their industry. The incentives for individuals who can obtain public works jobs to look for a private sector job are thus not high, and public works jobs surely crowd out private employment, reducing productivity. We thus recommend a gradual reduction in these programs. ${ }^{107}$

To help on the supply side, we recommend increasing spending on services offered to the unemployed through the public labor offices. Some

104. Our recommendations on infrastructure and capital subsidies echo the recent country report on Germany by the Organization for Economic Cooperation and Development (OECD Economic Survey: Germany, 2001).

105. See, for example, Lechner (2000).

106. Eichler and Lechner (1999).

107. Here we echo some recommendations of Schmidt and others (2001). 
pilot projects already under way are reducing the numbers of unemployed per case worker, and these should be evaluated and extended. ${ }^{108}$ It is reasonable to expect the unemployed to show evidence that they are indeed searching for work, and we approve of measures taken to limit the ability of the unemployed to receive benefits after rejecting job offers.

The textbook response to unemployment caused by high wages is a wage subsidy. Before making such a recommendation, however, we would have to devote more study to this issue specifically. In his survey of U.S. wage subsidy schemes, Lawrence Katz calls the overall results "highly uncertain." ${ }^{109}$ French wage subsidy schemes are even more difficult to evaluate than those in the United States, since France has several employment promotion projects operating concurrently. ${ }^{110}$

We have made some other interesting discoveries. First, we have clarified the mechanism by which high wages were successful in keeping people in the east despite rising unemployment. The high unemployment rate spurs those actually laid off to emigrate or commute, but those laid off are generally not in the youngest age group, which has the highest propensity to move. High wages in the east convince these youngest easterners to continue studying or looking for a first job there, even if unemployment is high. Thus, even if the sharp rise in wages caused unemployment, it kept people in the east through its effect on mobile youth.

Second, the labor market behavior of eastern female workers is strikingly similar to that of eastern male workers, and thus rather different in many regards from that of western female workers. This similarity is caused by a combination of several factors: the strong labor force attachment of eastern women, their low birth rate, their high representation in public sector employment, and a selection effect whereby the lowest paid were forced to leave employment. The much greater employment difficulties of women mean that their labor market outcomes are very unevenly distributed. They also mean that a return to full employment would bring less skilled women back to work, which would make a TFP measure that does not control for skill appear to fall.

108. See Jerger, Pohnke, and Spermann (2001) for a positive assessment of the Mannheim site.

109. Katz (1998).

110. Schmidt and others (2001) have argued in favor of wage subsidies and endorsed the scaling back of active labor market policies in Germany. 
A PPENDIX

\section{Capital Stock Estimates and the Solow Decomposition}

HERE WE APPLY a version of the familiar Solow growth accounting method to the recent growth of both eastern and western German states. Assume that real gross value added per year $Y$ in state $j$ during period $t$ is generated according to the following constant-returns production function $F$ :

$$
Y_{t}=F\left(K_{t}, L_{1 t}, \ldots, L_{N t}\right),
$$

where $K_{t}$ is the stock of productive equipment and $L$ is the stock of labor input for $i=1, \ldots, N$ age classes. The Solow decomposition in this case is given by

$$
\hat{Y}_{j t}=\hat{A}_{j t}+s_{K} \hat{K}_{i t}+\sum_{i} s_{L i} \hat{L}_{i t}
$$

where the carat denotes the time derivative of the logarithm of the variable (which can be approximated by percentage changes), and $s$ denotes the elasticity of $F$ with respect to each of the two inputs, which under competitive conditions in factor markets also equal income shares. $\hat{A}_{t} \equiv \hat{Y}_{t}-\sum_{i} s_{i} \hat{X}_{i t}$ is the relevant measure of total factor productivity, the Solow residual.

\section{Data}

For reasons of data availability, it was only possible to focus on capital and labor as observable production inputs for tracking the sources of growth. In particular, we considered only capital equipment as a measure of capital input. As noted in the text, eastern Germany has experienced a massive buildup of structures, especially housing, so that any Solow residual relying on these numbers would be biased downward to the extent that structures do not contribute to measured GDP. To strengthen the case against a TFP slowdown, we omit this variable entirely. In doing so we rely on the evidence adduced by DeLong and Summers $(1991,1992)$ that productivity and growth effects stem primarily from equipment investment. 
For the labor input, three different measures were considered. The first assumes a single homogeneous labor input $(N=1)$, which is total employment estimated in the German Mikrozensus survey. The second disaggregates employment into five age classes (twenty-four years and younger, twenty-five to thirty-four, thirty-five to forty-four, forty-five to fifty-four, and fifty-five to sixty-five); the third considers instead the entire workingage population, using the age classes adopted by the Federal Statistical Office (Statistisches Bundesamt; the age classes are eighteen to twentyfive, twenty-five to forty, forty to fifty, and fifty to sixty-five). We use the working-age population to obtain a crude measure of supply-side potential and to abstract from currently large differences in participation and unemployment rates across regions.

The output, investment, and price data come from the Arbeitskreis Volkswirtschaftsliche Gesamtrechnung der Länder (Working Group for State Income and Product Accounts), or AKVGRL, in Stuttgart. These data are series of real investment (at 1995 prices) and of output (at current and 1995 prices) for all sixteen states from 1991 to $1998 .{ }^{111}$

\section{Estimating Capital Stocks in Eastern Germany}

One important limitation of the data is the lack of publicly available estimates of the capital stock for the individual eastern German states (Berlin, Brandenburg, Mecklenburg-Western Pomerania, Saxony, SaxonyAnhalt, and Thuringia). Here we describe several approaches for estimating real capital stocks comprising both equipment and structures, public and private. It should be noted that the Solow analysis will focus on equipment capital stocks, although the method described below will be applied to both equipment and structures.

Capital stocks were estimated for each eastern state in each year using available investment data for equipment and structures. The first issue is the relevant transition equation for the capital stocks. For lack of a better alternative-statistical agencies employ detailed information on vintages and estimated lifetimes of equipment, but these were not available to us-

111. The limited availability of investment data for the west is related to the introduction of the new European System of National Income Accounts, which, as in the United States, modifies traditional investment data to include spending on software and related items. 
we estimated depreciation rates using data for the western German states reported by the Federal Statistical Office over the period 1991-98 (at 1991 prices, from the old national income accounts). In particular, let $K_{t}$ be the stock of capital at the end of period $t$ available for use in production in $t+1$ (where $t$ is a year), and let $I_{t}$ be the flow of investment purchases over period $t$. Depreciation rates were estimated as the ordinary least squares coefficients resulting from regressing $\left(\Delta K_{t}-I_{t}\right)$ on $K_{t-1}$. The results were as follows (standard errors are in parentheses): ${ }^{12}$

—equipment: $-0.0752(0.002)$

— structures: $-0.123(0.055)$

—total capital: $-0.094(0.044)$.

The second issue is that of the boundary condition for the estimation. One approach is to assume some initial condition sufficiently far back in time to be largely irrelevant. ${ }^{113}$ Another is to impose a long-run condition on the average capital-output ratio implied by the resulting estimate, but this is clearly inappropriate in an economy in transition. Furthermore, the remarkably poor condition of information on the value of the eastern capital stock makes it impossible at present to assess how much of the pre1990 capital stock is still in use, not to mention its market valuation, at the state level. We proceed nonetheless under the assumption that it is more important to set a bound on possible errors than not to generate any results at all.

In a first set of capital stock estimates, we simply impose the boundary condition that the value of eastern German equipment was zero in 1990. This is likely to be an underestimate, since some capital, especially structures, dating from before the fall of the Wall is still in use today. A second set of estimates assumes that the eastern German states reached a level of equipment capital intensity $(K / Y)$ equivalent to that in the western German state with the lowest capital intensity in 1998, namely, Bavaria (0.89). The second method attributes all of the observed east-west productivity

112. It is surprising that the depreciation rate for structures exceeds that for equipment. It suggests that depreciation in the German accounts used to estimate the capital stocks may come from financial data reported to the tax authorities (which are accelerated for certain types of structures).

113. The capital stock at $t+1$ is given by $K_{t+1}=(1-\delta) K_{t}+I_{t}=(1-\delta)^{i} K_{t-T}+$ $\Sigma_{0}^{T-1}(1-\delta)^{i} I_{t-i} \cdot$ 
gap in 1998 to TFP differentials. Thus, by the end of 1998, the capitaloutput ratios in all states are assumed to have converged to that of Bavaria. In this case the benchmark calculation simplifies to

$$
K_{E}^{*}=(K / Y)_{\text {Bavaria }} Y_{E}
$$

Using this method generates the following benchmark values of $K / Y$ :

—equipment: 0.89

—structures: 3.65

-total capital: $4.58 .{ }^{114}$

The second approach is likely to result in an overestimate, since some convergence of productivity at a given capital endowment has certainly occurred: some eastern German plants are now more productive than their western counterparts. It does, however, reflect an increasingly widespread opinion that the east has already accumulated an adequate physical capital stock and that its problems lie elsewhere. ${ }^{115}$ Nevertheless, it is possible, using these estimates, to backcast an implicit value of the 1990 capital stock consistent with the observed investment series and our depreciation rate for equipment. We will consider these two estimates of the initial capital stock as extremes that set a bound on actual performance in the eastern German states, at least for equipment. We use 7.52 percent as the depreciation rate in estimating the two series for the eastern German equipment capital stocks, which we denote henceforth as $\underline{K}$ and $\bar{K}$.

For consistency we applied the same estimation technique to the western data, using the 1990 year-end values of the capital stocks, with a price deflator adjustment, as initial conditions. As a check we also conducted the analysis using discontinued western capital stock data, at 1991 prices, constructed by the Federal Statistical Office.

114. A third set of estimates, not presented here, assumes that the remaining productivity gap in 1998 in eastern vis-à-vis western Germany is a function of a deficient capital intensity only. Assume a common Cobb-Douglas technology in both regions in 1998, so that the ratio of labor productivities $\theta_{i}$ with respect to some benchmark western state $W$ is given by $(Y / L)^{i} /(Y / L)_{W}=\left[(K / L)_{i} /(K / L)_{W}\right]^{\alpha}=\left[(K / Y)_{i} /(K / Y)_{W}\right]^{\alpha /(1-\alpha)}$. Setting $\alpha=0.27$, the equation for the benchmark year 1998 is $K_{E}^{*}=\theta^{(1-\alpha) / \alpha}(K / Y)_{W} Y_{E}$. This approach led to low capitaloutput ratios in 1998 and, in half of the cases, to negative initial values of the capital stock in 1990. Evidently, the assumption of common technology is rejected by the data.

115. See Ragnitz (2000, 2001) and Heimpold (2001). 
There is a remarkable variance of $K / Y$ among the western states, originating almost entirely from structures, which we take to reflect differing housing stocks and population densities. This vindicates our exclusion of this variable from the analysis, since it is not a first-order indicator of future productive potential (DeLong and Summers, 1991, 1992).

\section{Solow Decomposition over Time and Space}

Using the data generated above, we then carried out the Solow decomposition exercise given by equation A2 for the single homogeneous labor input, for labor disaggregated by age, and for the working-age population disaggregated by age. Only the results for $\bar{K}$ are reported, since these would tend to be less biased toward detecting a productivity growth slowdown. Factor shares were estimated from the GSOEP and from the German national income and product accounts. ${ }^{116}$ The output data correspond to those reported in AKVGRL (2001) for gross value added less subsidies and net interest. These data span the period 1991-2000. For the western states, output data are available before this but do not correspond to the new European System of National Accounts. For lack of a better alternative, we simply chained the pre-1991 output data after equating the values of both series in 1991 .

We also used a spatial variant of the Solow calculation, explaining deviations in the logarithm of output across units at a given point in time rather than accounting for increments to output over time. ${ }^{117}$ The advantage of this approach is that it yields levels of multiplicative TFP as an immediate result; its main disadvantage is that it is much more sensitive to measurement errors in the capital stock data, which are differenced away in the time-based Solow procedure. The approach also imposes a common production function on the two regions, which strictly speaking is not necessary for computing TFP growth with individual units. For the $j$ th sector, then, we have

116. The national capital and labor shares are averages over the period 1991-99, taken from Sachverständigenrat zur Begutachtung der gesamtwirtschaftlichen Entwicklung (2000), and equal 0.274 and 0.726 , respectively.

117. Robert Hall suggested this approach during the general discussion of the paper at the Brookings Panel conference, and Janet Yellen employs essentially the same approach in the back-of-the-envelope estimates of TFP gaps presented in her comment. 
(A3) $\ln \left(\frac{A_{j W E S T}}{A_{j E A S T}}\right)=\ln \left(\frac{Y_{j W E S T}}{Y_{j E A S T}}\right)-\left[s_{K} \ln \left(\frac{K_{j W E S T}}{K_{j E A S T}}\right)+\sum_{i=1}^{N} s_{L i} \ln \left(\frac{L_{j W E S T}}{L_{j i E A S T}}\right)\right]$,

where $s_{K}$ and $s_{L i}$ now represent arithmetic averages of the eastern and western factor shares. We were not able to obtain factor shares information by age group at the sectoral level, and so we approximate it by taking the national values employed in the computation of the time-based Solow residuals. Since production is linear homogeneous, equation A3 can be rewritten with one type of labor as

$$
\ln \left(\frac{A_{j W E S T}}{A_{j E A S T}}\right)=\ln \left(\frac{Y_{j W E S T} / L_{j W E S T}}{Y_{j E A S T} / L_{j E A S T}}\right)-s_{K} \ln \left(\frac{K_{j W E S T} / L_{j W E S T}}{K_{j E A S T} / L_{j E A S T}}\right) .
$$

Using Ragnitz's (2000) estimate of the east-west $K / L$ in 1998 for mining and manufacturing (0.955), the east-west ratio of labor productivity (per person employed) in the same year (0.723), and a value for $s_{K}$ of 0.274 , we obtain a value for the left-hand side of equation A4 of $\ln (0.72)-$ $(0.274) \times \ln (0.955)=-0.3117$, which yields an east-west TFP ratio of $\exp (-0.3117)=0.732$. Clearly, at given factor shares, the capital gap must be large to explain much of any productivity gap. 


\section{Comments and Discussion}

Holger Wolf: This paper by Michael Burda and Jennifer Hunt takes a thorough and instructive look at labor market developments in eastern Germany over the last decade, ending on a refreshingly optimistic note.

One of the debates at the beginning of the unification process concerned the relative economic merits (or demerits) of transition with and without unification. Ex post, the glass is both half full and half empty. Sustained fiscal transfers have avoided a consumption slump; indeed, consumption per capita has increased consistently to reach the preunification standard in the former West Germany. Public sector infrastructure investments, partly financed by these transfers and the diffusion of market economy expertise and integration into the European Union, have also provided the former East Germany with substantial competitive advantages relative to the other central European transition economies. Following a very sharp initial decline, growth performance since 1991 has been in line with that in the other transition economies.

Yet unification, which largely took the form of East Germany adopting West German institutions, also imposed costs. Although this proved highly advantageous in some fields, including accounting and taxation, institutions in other sectors were not adapted to the special needs of a transition economy. In particular, the western German labor market system with its low degree of wage differentiation was quite inappropriate for the conditions of an early-stage transition economy. Coupled with the strong political push for income equalization and the initial lack of capital, job losses far exceeded those in other transition economies, although the social consequences were buffered by the extension of the social safety net. 
A second early debate focused on likely convergence scenarios. Under the neoclassical scenario, integration would lead to rapid convergence due to factor mobility and the free flow of technology. A less optimistic scenario envisaged a small, lower-productivity economy joining a larger, high-productivity economy enjoying economies of scale, and ending up losing its manufacturing sector and specializing in sectors with relatively slow productivity growth.

The aggregate evidence on convergence suggests an initial spurt followed by a stabilization of relative productivity in eastern Germany at a level significantly below that in western Germany, alongside a dramatic relative shrinkage of the manufacturing sector and a relative underrepresentation of large firms. Is this cause for concern? After all, certain regions in other countries have displayed prolonged gaps in total factor productivity. Why, then, should one be surprised at, or concerned about, a persistent productivity gap between eastern and western Germany? Yet eastern Germany is arguably different from Appalachia or the Mezzogiorno, for two reasons. First, whereas those regions have a long history of Gerschenkronian relative backwardness, and may thus be seen as suffering from other growth-impeding factors, large areas of eastern Germany had been part of the industrial heart of prewar Germany. Second, there have been few historical instances of as large and as rapid an increase in the capital-labor ratio as in eastern Germany over the last decade, with cumulative investment per worker close to $\$ 100,000$.

How believable are the data on convergence? A few points are noteworthy. The first concerns the point of reference. The original expectation-and hope-voiced after the breaching of the Berlin Wall was that the east would soon attain Western living standards, which one might interpret as the western German living standard at the time. A decade later, eastern Germany has in fact reached the material living standards of West Germany in 1989, and even productivity is catching up to the West German level of that year. A good part of the remaining gap thus reflects not so much subpar growth in eastern Germany, but rather the acceleration of growth in western Germany since unification. This was, of course, endogenous: the lion's share of the transfers from western to eastern Germany was spent on goods produced in western Germany, generating a first-order demand effect.

Second, statistical problems must be kept in mind. Some data, in particular those for initial GDP per capita, are subject to a wide confidence 
interval, as is, consequently, the measured speed of convergence; the convergence picture is also somewhat rosier when data based on the European System of National Accounts are used.

Third, differentiating the convergence pattern by sector as well as by state reveals dramatic differences. The early 1990s witnessed both a rapid expansion of public sector construction and a private construction boom, partly reflecting very generous tax provisions. Measured productivity rose sharply. Following the winding down of the construction boom in the second half of the decade, however, some of the initial gains have been reversed. To what extent this measured productivity increase should be interpreted as organic convergence, rather than as a temporary margin expansion, is an open question. The public sector likewise displayed rapid initial convergence in measured productivity, partly reflecting productivity gains, but partly reflecting the push toward wage equalization. Following wage equalization, relative measured productivity has been stable.

Much of the initial sharp increase in measured productivity, as well as a good deal of the subsequent stagnation, reflects developments in these two sectors, both of which are arguably influenced by one-time factors. A sharply different picture emerges for the manufacturing sector, which, after an initial steep decline, has shown more steady, if small, productivity gains. To the extent that one believes that the convergence in productivity primarily reflects technological adaptation rather than wage agreements or public construction programs, the convergence picture looks rather more promising, although the importance of manufacturing in total output has sharply declined.

A very interesting part of the paper is the attempt to estimate productivity gaps between east and west. The approach is based on a regression linking wages to observable characteristics within western Germany. Applying the regression coefficients to the characteristics of eastern German workers permits the computation of the hypothetical wage that these workers would be earning in western Germany. Comparing these hypothetical wages with actual wages results in an estimate of the residual productivity gap at each skill level. The authors find that this gap has shrunk over time for all skill levels but remains significant.

The methodology rests on strong assumptions, notably that differences in characteristics provide significant explanatory power for wages in western Germany; that the same characteristics are relevant, and have the same relative importance, for eastern as for western workers; and that actual 
wages reflect individual productivity. Although the explanatory power of the wage regression allows one to gauge the validity of the first assumption, the other two are more difficult to assess. In this light, the evidence that convergence is substantially less apparent for jobs requiring relatively high skill is of interest, given the paper's observation that firm headquarters are relatively underrepresented in the eastern states, suggesting a relative scarcity of managerial jobs.

Janet Yellen discusses many of the potential explanations of the remaining productivity gap. One that might be added, and which Michael Burda mentioned in his presentation, is migration. In particular, if, among a set of individuals with the same measurable characteristics, those with the highest overall productivity (including productivity differences not attributable to measurable characteristics) are more likely to move to the west, a systematic bias may arise. On the other hand, the inverse argument applies to the policies used to reduce labor supply: one might suppose that, again among a subgroup of individuals with the same observable characteristics, those with the lowest productivity might have been more likely to avail themselves of financial incentives to leave the labor force.

The authors make a convincing case against a capital stock gap as a complete explanation of the remaining productivity gap. Here a sectoral perspective might again be worthwhile, as tax incentives and the initially high relative unit labor costs have tilted the production structure toward relatively more capital-intensive sectors.

In conclusion, the paper presents an excellent discussion of the evolution of labor market institutions and performance in the decade after unification, painting a refreshingly optimistic picture. Going forward, one of the most interesting questions is whether the reform of labor markets from below that the paper documents will mitigate the persistent unemployment problem, particularly among lower-wage workers.

Janet L. Yellen: A decade ago, economists debated whether eastern Germany would become another German Wirtschaftswunder or, instead, another Mezzogiorno. This fascinating paper details the verdict, which is that both extreme views were simultaneously right and wrong. The authors show that substantial progress was made between 1991 and 1995 in closing the productivity gap with western Germany.

But then productivity growth stalled. A gap of around 25 to 30 percent still remains. Growth accounting shows that the remaining gap is mainly 
due to lower total factor productivity than in the west. Eastern wages followed a path similar to productivity, rising rapidly following unification, then stabilizing at around 75 percent of western levels after 1995. The skill structure of wages in the east also changed after unification. Whereas initially wage inequality was lower than in the west, now the return to skill is strikingly similar. All is not well in the labor market, however: employment has declined, labor force participation is down, and unemployment has risen to about 19 percent of the work force. A higher nonemployment rate in the east than in the west translates into a gap in GDP per capita that exceeds the gap in productivity. The shortfall in consumption per capita (about 27 percent) is smaller than the gap in GDP per capita (about 35 percent), however, thanks to substantial and continuing social insurance transfers from the west. With high unemployment and a continuing wage gap in the east, net migration to the west continues, particularly among young people, but the pace of outward migration has slowed substantially.

The authors pose three interesting questions concerning these developments: Why did productivity rise rapidly, then stall? Why does unemployment remain stubbornly high? Did high eastern wages diminish outmigration or increase it? I will discuss the authors' analysis of each of these issues.

Why did labor productivity rise rapidly, then stall? The collapse of the Berlin Wall triggered three adjustments, which were responsible for the rapid productivity gains that followed: massive capital spending financed by the west, the closure of unproductive eastern German firms, and an influx of ideas. In 1991 labor productivity in the east was 44 percent of western levels. Very little of the gap, in the authors' estimation, reflected a shortfall in human capital: eastern German levels of education and training were close to, indeed arguably higher than, those in the west. But a substantial portion of the gap reflected the huge shortfall in physical capital. As soon as the Wall collapsed, western Germany began the expensive task of rebuilding the east. It provided massive support, which continues today. Aggregate investment between 1991 and 1998 exceeded DM 1.5 trillion and averaged over DM 11,000 per eastern German resident a year. Some 30 percent of this consisted of equipment investment (according to the authors' table 5). Large investment subsidies induced some prominent western German firms to establish capital-intensive facilities in the new states. 
To apportion the improvement in eastern German productivity after 1991 between factor accumulation and TFP, the authors perform a standard growth accounting analysis. Their analysis focuses on equipment investment, ignoring structures, but their conclusion, that the bulk of the remaining productivity gap - about 28 percent-is due to TFP, is quite robust. Consider, for example, a back-of-the-envelope exercise using a recent estimate that, by 1998, capital per worker (including both equipment and structures) had reached 76 percent of western levels. ${ }^{1}$ With an assumed capital share of one-third, a 24 percent shortfall in capital per worker translates into only an 8 percent shortfall in output per worker. The remainder of the current productivity shortfall—-the lion's share, about 20 percent—must be due to TFP.

In addition to triggering a surge of investment to rebuild the east, unification produced an improvement in TFP through two separate channels. The first channel involved rapid liquidation of unproductive eastern activities. The Treuhandanstalt was charged with privatizing eastern industry. It accomplished its task quickly, closing or downsizing inefficient operations in the process. Since eastern German wages were high at the outset and scheduled to rise to parity with the west, very few eastern jobs turned out to be viable. A significant portion of the initial TFP surge thus reflected one-shot gains from closing low-productivity eastern activities.

I witnessed an example of this survival of the fittest on a 1991 visit to the Eisenhüttenstadt Steel Works. The old part of the mill, which had employed most of the workers, was an idle, rusting hulk. Production continued in the far corner of the mill, sparsely staffed and controlled by computer. This remaining portion of the plant contained equipment recently purchased from Austria. It awaited sale to a western buyer. This steel mill at Eisenhüttenstadt is paradigmatic of the eastern German manufacturing sector as a whole: out with the old, preserve the new, and reap very large gains in productivity, as manufacturing shrinks rapidly in size. Between 1991 and 2000, labor productivity in manufacturing relative to the west more than tripled.

The collapse of the Wall also raised TFP through a third mechanism: the importation of new ideas, new methods of production, and new inputs. The Wall had placed constraints on the movement of ideas and inputs,

1. Ragnitz (2000). 
not just on the movement of people. When it came down, western firms, managers, ideas, and equipment went east. Firms were quickly reorganized, raising efficiency. New firms were established in the east to satisfy growing (western-subsidized) eastern German spending on nontradables and for construction. Productivity improved where eastern firms were taken over by western enterprise. It also improved in eastern enterprises. For example, by 1996 the fraction of self-employed service workers in the east was comparable to that in the west. Service productivity had improved substantially.

The authors regard the remaining 30 percent gap in productivity between east and west as a puzzle, and they postulate several reasonable explanations. One is that eastern products often sell at a discount. The authors wonder why the deficiencies in marketing skills that this suggests have not been remedied in the eleven years since monetary union.

But should we be surprised at the persistent gap in productivity? In international perspective the remaining TFP gap is modest. For example, Robert Hall and Charles Jones, using 1988 data, estimated that TFP in Germany was 10 percent below U.S. and Canadian levels, 15 percent above levels in Norway and Denmark, and almost 20 percent above levels in New Zealand and Japan-all advanced industrial countries. ${ }^{2}$ Even within Germany, income per capita in Hamburg and Bremen exceeds the national average by 71 percent and 35 percent, respectively. Income per capita in Connecticut is almost twice that in West Virginia.

In addition, manufacturing makes up a larger share of output in western than in eastern Germany, and TFP growth is probably higher in manufacturing than in services. In a neoclassical model, with integrated capital and labor markets, divergent TFP across sectors is compatible with factor price equalization but requires a trend increase in the relative prices of low-productivity products-in other words, terms-of-trade effects. The authors' table 8 presents estimates of such effects, but they appear to be far too small to explain the gap.

Agglomeration effects and intangible assets are probably more important than industry mix effects in explaining the remaining TFP gap. We know that firms locate in cities such as San Francisco, New York, and Boston despite their high rents, to take advantage of their specialized business services and networks. The inferior quality of business services in

2. Hall and Jones (1996). 
eastern Germany is thus a telltale. And there is little evidence that western firms are moving production to the east to take advantage of lower costs. The main motive is apparently to sell in eastern markets and, in some instances, to take advantage of large investment subsidies-the Mezzogiorno phenomenon.

A third explanation for the remaining TFP gap is that there is an eastern deficit in intangible assets: brands, organizational or specific human capital, loyal or locked-in customers, intellectual property (including patents), and deep business networks. Eastern Germany's intangible investments were largely wiped out with the fall of communism, because East Germany's industries had catered to Russian and Eastern European clients. The 1991 study by George Akerlof and others found only a single eastern German firm outside the energy sector that would clearly be profitable after unification. ${ }^{3}$ That firm, the State Porcelainworks of Meissen, had intangible assets accumulated over three centuries. The authors note that eastern German firms are smaller, younger, less established, and more specialized in nontradable goods. And their table 15 reveals a huge firm-size effect on wages, suggesting that small firms, because of their lower productivity, cannot afford higher wages. Interestingly, the authors note that one researcher (Joachim Ragnitz) finds that small firm size explains 17 percent of the raw productivity gap. This pattern reflects an eastern German "intangibles" gap.

Why does unemployment remain so stubbornly high? The existence of chronic, large-scale involuntary unemployment in eastern Germany, in my view, can have only one interpretation: wages exceed their marketclearing level. Surprisingly, the authors come to this conclusion only reluctantly: they say that "despite the difficulty of demonstrating it concretely ... [they] are inclined to believe that wages have risen too fast." One reason for their reluctance is that they find no "conclusive evidence from relative wages or employment of distortionary effects of wage floors, be they union wages or welfare benefits."

The authors note that just before and immediately after unification, unions won huge wage increases, bidding wages well above marketclearing levels. They document, however, that union membership has since declined-from about 51 percent to 33 percent of eastern workers-along with membership in employers' associations. Wage agreements are

3. Akerlof and others (1991). 
frequently being struck outside the bargaining framework, and concession bargaining is increasingly common. With the unions' influence having waned, the authors see few barriers now to the attainment of marketclearing wages.

However, unions are not the only reason why wages might be too high to clear the market. Initial conditions- - high wages at unification coupled with the promise of rapid equality with the west-have surely left a mark on the labor market. The growing prevalence of concession bargaining in the east provides evidence that wages are still too high, not that they are market clearing. In his interviews at Connecticut firms, Truman Bewley found that firms almost never cut wages until they are on the brink of bankruptcy. ${ }^{4}$ The low levels of job changing in eastern Germany are further evidence that wages are above market-clearing levels: those lucky enough to have jobs are reluctant to leave them.

Efficiency wage models offer many reasons why firms might pay wages in excess of what would clear the market: social custom, ability to pay, fairness considerations, insider-outsider considerations, and the need to motivate hard work. In our 1990 survey of workers in eastern Germany, for example, 76 percent considered it unfair for western German firms that set up enterprises in eastern Germany to pay lower wages than in the west, even in the presence of high unemployment. ${ }^{5}$ On the other hand, they did not consider it unfair for wages generally to be below the western German level, and they were willing to take large wage cuts to obtain work. Indeed, the finding by Burda and Hunt of a huge effect of firm size on wages suggests that wage bargains may reflect "ability to pay." Profitable, modern western German firms are expected to pay western wages, but struggling eastern German firms can continue to pay the lower wages they need to survive.

The authors dismiss the possibility that high unemployment benefits contribute to unemployment, on the grounds that the unemployment is involuntary, not voluntary. However, in richer models of wage determination, such as the Shapiro-Stiglitz worker discipline model, unemployment insurance benefits affect wage bargains and the level of involuntary unemployment in equilibrium. In the Shapiro-Stiglitz model, firms pay a premium above workers' reservation wages to create a surplus that moti-

4. Bewley (1999).

5. Akerlof and others (1991). 
vates hard work. If eastern workers can claim high unemployment benefits relative to their productivity, this could partly account for high eastern wages and involuntary unemployment.

Another reason why the authors believe that market forces are operative in the eastern labor market is that they find that the return to skill and the degree of wage inequality in the east have greatly increased. Indeed, they now mirror western patterns at the time of unification. Such large increases in inequality should have been expected, however, if only because income equality had been such a special priority in the former East Germany. The similarity of wage patterns between east and west, although an interesting surprise, does not necessarily indicate that wage levels are market clearing.

The recognition that wages have exceeded market-clearing levels since the outset of the transition produces a different view of the convergence process from that summarized in the authors' figure 1. In the authors' framework, integration creates the incentive for capital to move east and labor to move west, with the ultimate scale of eastern economic activity hinging on the speed of adjustment (although a chronic TFP gap is inconsistent with wage equalization). The authors cite an "increasingly widespread opinion that the east has already accumulated an adequate physical capital stock and that its problems lie elsewhere." The paper documents that investment in the east has been sufficient to raise the eastern equipment capital-output ratio to western levels, so that a shortage of capital does not primarily account for the remaining productivity gap. But a different perspective suggests that investment has been inadequate in eastern Germany.

Eastern Germany needed enough investment to create jobs for its entire work force, not just enough to attain western capital-output ratios in the few enterprises that were viable. With eastern wages excessive, very few jobs could profitably be created. It is true that, when western firms went east, typically with large capital subsidies, they established operations such as automobile assembly plants that were similar in capital intensity to their western counterparts. But these investments provided only a handful of jobs. The authors' table 5 provides additional evidence that investment was insufficient in the east. It shows that eastern investment per capita, as opposed to per worker, exceeded the level in the west by only 19 percent when housing and infrastructure are included. Equipment investment per capita was actually lower in the east. My conclusion is that high wages discouraged and continue to discourage the investment that is needed for job 
creation. A telltale sign is that, contrary to the usual factor price equalization mechanism, labor-intensive businesses in the west are not moving east. A simple calculation suggests that, with a 20 percent TFP gap and a 25 percent wage gap, the marginal rate of return to capital in the east is no higher than in the west. Not surprisingly, a major complaint of eastern firms is that unit labor costs are too high.

Did high eastern wages diminish migration or increase it? The final question that the authors address is whether high eastern wages kept people in the east. Their conclusion is unambiguous: "labor unions were correct in expecting that high wages would keep people in the east. . . on balance, high wages in the east reduced emigration." This conclusion relies on a set of interesting regressions using data from the German SocioEconomic Panel to examine the determinants of migration among German regions. The regressions show that young people are sensitive to wage differentials and insensitive to (or perversely affected by) source unemployment. Older workers, in contrast, respond significantly to source unemployment, and a substantial share of migrants are workers who have been laid off.

The authors' disaggregated results are entirely plausible and accord closely with the survey findings of Akerlof and others concerning migration intentions a decade ago. Eastern Germans appear to have behaved just as they themselves anticipated back then. But I am uncertain that the authors' conclusion - that high wages kept eastern Germans home-automatically follows. For although high wages may have deterred young people from going west, they also caused high unemployment, driving nonstudents to migrate. The net impact of wages on migration requires an assessment, which the paper does not undertake, of which effect was larger. In sum, I think we should be quite cautious in accepting the conclusion that, for eastern Germany as a whole, higher wages meant less rather than more emigration.

In conclusion, the authors have done an outstanding job of asking the right questions about convergence and providing a wealth of data and analysis on which to base judgments. They conclude on an optimistic note that convergence may soon resume, encouraged by signs of growing wage flexibility. I remain skeptical. The TFP gap will take a long time to close. And with wages above the market-clearing level, the return to capital is too low to spur enough investment in eastern Germany to absorb unemployed workers. Young people seem likely to migrate, on net, for the foreseeable future. 
General discussion: Much of the discussion centered on the applicability of Solow growth accounting to the eastern German transition. Steven Durlauf wondered whether the standard tools are appropriate in this case. Observing that the paper's analysis could have been applied equally well to differences between upstate and downstate New York, he expressed concern over the lack of attention to what might be called post-Iron Curtain exceptionalism. In particular, he questioned the appropriateness of using the Solow model for productivity calculations when the economic environment in eastern Germany appeared to violate at least two of the model's underlying assumptions, namely, competitive factor markets and a timeinvariant production function augmented by technical progress. Most research, he noted, finds factor markets in eastern Germany to be uncompetitive, and it is likely that preunification East Germany was far from the efficiency frontier. The sheer magnitude of social and economic reorganization in the decade following unification is itself inconsistent with the notion of a stationary production function. Hence it is not likely that growth in the first part of the period is well described as movement along a production function with factor accumulation, shifted by the normal evolution of technology. The reorganization of production could be treated as a nonstationarity in the production function's evolution over the 1990s: the early convergence could be captured by an outward shift, and the subsequent slowdown seen as a return to the normal growth process, with diminishing returns from factor accumulation. But conventional growth accounting would not do a good job of explaining what was going on during the early transition.

William Nordhaus agreed with the thrust of Durlauf's remarks. He mentioned four potential problems with using the Solow model in the eastern German setting. First, the Solow model is basically a representativefirm economy in which changes in output are explained with changes in capital and labor, whereas much of the productivity increase in eastern Germany has resulted from a dramatic wringing out of large, inefficient firms. This phenomenon is quite different from changes in factor quantities or the normal process of technological advance. The reduction in average firm size in eastern Germany during the transition has been striking. Second, if there are large differences in measures of output per unit of input across sectors of an economy, sectoral shifts can distort estimates of TFP growth. In construction, for example, value added per unit of labor is relatively high, so that the measured growth path for TFP in eastern Germany 
might represent an initial shift toward construction in the beginning of the 1990s followed by a movement away as the decade progressed. Third, Nordhaus noted, differences in structures rather than in equipment expenditure account for most of the investment gap between east and west. He reasoned that if a substantial portion of the investment in structures in eastern Germany is public investment, then, because productivity measurements on public capital are underestimated, the measurement of TFP growth in the east is biased downward. Finally, he argued that the model's assumption of constant returns to scale is almost surely invalid in the case of eastern Germany during this period. Joseph Stiglitz pointed out that theories of embodied technical change predict that eastern Germany's high levels of investment in technology should have increased productivity a lot. That this did not occur, Stiglitz noted, should lead one to be skeptical of the Solow methodology in this setting.

Robert Hall found the concerns about the applicability of the Solow model overdone. He thought that the alleged nonstationarity of the production function could easily be accommodated by changes in efficiency over time, and that estimates of the elasticity of output with respect to factor inputs from observed shares are not significantly in error even if factor markets are not perfectly competitive. Furthermore, he himself had found that productivity calculations are quite robust to reasonable variations in the estimated shares. Hence he believed the Solow model provided a useful framework for estimating the rate of TFP growth. He also thought the framework was useful in explaining the relative productivities of eastern and western Germany. He noted, however, that if estimates of the factor shares are different in two regions, it is important to use their average. Edmund Phelps was not surprised by the TFP gap between the two Germanys toward the end of the period. He suggested that it might well represent a steady-state outcome explained by the diffusion of technological innovations. He observed that the TFP gap in Germany was comparable to that between northern Italy and the Mezzogiorno, and he identified the relative lack of university-trained managers in the low-TFP regions as a common feature that might explain the similarities in the two comparisons.

Edward Glaeser suggested that unobserved differences in human capital might be responsible for the gap in TFP between eastern and western Germany. The paper controls for these omitted human capital characteristics by comparing the wages of eastern Germans in the west with wages 
earned by comparable western Germans, finding little difference. Glaeser argued, however, that this conclusion might be weakened by the possible selectivity of the migrants.

Richard Cooper thought there was something to the observations by workers from eastern Germany who had migrated to western Germany in the mid-1990s and reported upon their return that "It's true, they have shorter workdays there, but they work every hour of them." The increase in unemployment in the east to very high levels may largely reflect movement from leisure on the job to leisure off the job. He went on to question whether these high unemployment rates represent involuntary unemployment rather than simply a high reservation wage. Cooper found support for the hypothesis that much unemployment is voluntary in the high proportion of foreign guest workers in the reconstruction of Berlin. He noted that, if his view is correct, lower wages would actually increase rather than decrease unemployment. Stiglitz acknowledged that employment might have been discouraged by a generous welfare system, but he thought that low labor productivity was clearly part of the problem, making it difficult for eastern German firms to pay wages consistent with standards and wage aspirations heavily influenced by conditions in the west.

Stiglitz further observed that unification has minimized many of the political and economic problems that have plagued other transition economies; this makes the eastern German experience particularly informative. He noted three unique and beneficial aspects of eastern Germany's transition stemming from unification: free trade with the neighboring west, easy adoption of a western legal and institutional structure, and very rapid privatization because of the immediate presence of western German firms. Yet productivity in the east had still failed to converge with that in the west. 


\section{References}

Acemoglu, Daron, and Fabrizio Zilibotti. 2001. "Productivity Differences." Quarterly Journal of Economics 116(2): 563-606.

Aghion, Philippe, and Olivier Blanchard. 1994. "On the Speed of Transition in Central Europe.” In NBER Macroeconomics Annual, edited by Stanley Fischer and Julio Rotemberg. MIT Press.

Akerlof, George A., and others. 1991. "East Germany in from the Cold: The Economic Aftermath of Currency Union.” BPEA, 1:1991, 1-87.

Arbeitskreis Volkswirtschaftliche Gesamtrechnungen der Länder. 2001. Aktuelle Länderergebnisse 1991 bis 2000. Stuttgart: Statistisches Landesamt BadenWürttemberg.

Aschauer, David. 1989. "Is Public Expenditure Productive?" Journal of Monetary Economics 23(2): 177-200.

Barro, Robert J., and Xavier Sala-i-Martin. 1991. "Convergence across States and Regions." BPEA, 1:1991, 107-58.

- 1992. “Convergence.” Journal of Political Economy 100(2): 223-51. 1995. Economic Growth. McGraw-Hill.

Bauer, Thomas K. 1995. “The Migration Decision with Uncertain Costs.” Münchener Wirtschaftswissenschaftliche Beiträge 95-25. University of Munich.

Beblo, Miriam, Irwin L. Collier, and Thomas Knaus. 2001. "The Unification Bonus (Malus) in Postwall Eastern Germany.” Discussion Paper 01-29. Mannheim, Germany: Zentrum für Europäische Wirtschaftsforschung.

Bedau, Klaus-Dietrich. 1996. "Löhne und Gehälter in Ost- und Westdeutschland gleichen sich an, Lohnstückkosten jedoch nicht." DIW-Wochenbericht 08-96: 1-4.

Begg, David, and Richard Portes. 2001. "Eastern Germany Since Unification: Wage Subsidies Remain a Better Way." In Employment Policy in Transition: The Lessons of German Integration for the Labor Market, edited by Regina T. Riphahn, Dennis J. Snower, and Klaus F. Zimmermann. Berlin: SpringerVerlag.

Bellmann, Lutz. 1994. "Plädoyer für Lohnkostensubventionen in den neuen Bundesländern." In Arbeitsmarktpolitik nach der Vereinigung, edited by Hubert Heinelt, Gerhard Bosch, and Bernd Reissert. Berlin: Edition Sigma.

Bellmann, Lutz, and Martin Brussig. 1998. "Ausmass und Ursachen der Produktivitätslücke ostdeutscher Betriebe des Verarbeitenden Gewerbes." Mitteilungen aus der Arbeitsmarkt- und Berufsforschung 31(4): 648-60.

Bentivogli, Chiara, and Patrizio Pagano. 1999. "Regional Disparities and Labour Mobility: The Euro-11 versus the USA." Labour 13(3): 737-60.

Bewley, Truman F. 1999. Why Wages Don't Fall during a Recession. Harvard University Press.

Blum, Ulrich, and Simone Scharfe. 2001. "Quo Vadis Ostdeutschland: Der Aufholprozess aus der Sicht der Entwicklungsökonomik.” In Zehn Jahre 
deutsche Einheit: Bilanz und Perspektiven, edited by Joachim Ragnitz. Halle, Germany: Institut für Wirtschaftsforschung, Halle.

Bode, Otto F., and Kai Hirschmann. 1992. Qualifizierungsmassnahmen: Aktive Weiterbildung als Alternative zur Transformationsarbeitslösigkeit. Marburg, Germany: Metropolis.

Boeri, Tito. 2000. Structural Change, Welfare Systems and Labour Reallocation: Lessons from the Transition of Formerly Planned Economies. Oxford, England: Oxford University Press.

Burda, Michael C. 1990. "The Consequences of German Economic and Monetary Union." CEPR Discussion Paper 449. London: Centre for Economic Policy Research. (Also published as "Les Conséquences de l'Union Economique et Monétaire de l'Allemagne," Revue de l'OFCE, October 1990, and in A l'Est, En Europe, edited by Jean-Paul Fitoussi, Paris: Fondation Nationale de Science Politique.)

- 1991. "Labor and Product Markets in Czechoslovakia and the Ex-GDR: A Twin Study." European Economy Special Issue 2: 111-28.

_ 1993. "The Determinants of East-West German Migration: Some First Results." European Economic Review Papers and Proceedings 37(2-3): 452-61. 1995. "Migration and the Option Value of Waiting." Economic and Social Review 27(1): 1-19.

_ 2001. "Notes on Regional Integration." Unpublished paper. HumboldtUniversität zu Berlin.

Burda, Michael C., and Ulrich Busch. Forthcoming. "West-Ost-Transfers im Gefolge der deutschen Vereinigung." Konjunkturpolitik.

Burda, Michael C., and Michael Funke. 1995. "East Germany: Can't We Be More Optimistic?" ifo Studien 41(3): 327-54.

— 2001. "Wages and Structural Adjustment in the New German States." In Employment Policy in Transition: The Lessons of German Integration for the Labor Market, edited by Regina T. Riphahn, Dennis J. Snower, and Klaus F. Zimmermann. Berlin: Springer-Verlag.

Burda, Michael C., and Christoph Schmidt. 1997. "Getting behind the East-West Wage Differential: Theory and Evidence." In Wandeln oder Weichen-Herausforderungen der wirtschaftlichen Integration für Deutschland, edited by Rüdiger Pohl and Hilmar Schneider. Halle, Germany: Institut für Wirtschaftsforschung, Halle.

Burda, Michael C., and others. 1998. "Semiparametric Analysis of German EastWest Migration Intentions: Facts and Theory." Journal of Applied Econometrics 13(5): 525-41.

Card, David, Francis Kramarz, and Thomas Lemieux. 1999. "Changes in the Structure of Relative Wages and Employment: A Comparison of the United States, Canada and France." Canadian Journal of Economics 32(4): 843-77.

Collier, Irwin L., and Horst Siebert. 1991. "The Economic Integration of Post-Wall Germany.” American Economic Review 81(2): 196-201. 
Collins, Susan M., and Dani Rodrik. 1991. "Eastern Europe and the Soviet Union in the World Economy." Policy Analyses in International Economics 32. Washington: Institute for International Economics.

DeLong, J. Bradford, and Lawrence H. Summers. 1991. "Equipment Investment and Economic Growth." Quarterly Journal of Economics 106(2): 445-502.

- 1992. "Equipment Investment and Economic Growth: How Strong Is the Nexus?” BPEA, 2:1992, 157-99.

Denison, Edward F. 1967. Why Growth Rates Differ: Postwar Experience in Nine Western Countries. Brookings.

Dietz, Barbara. 1999. "Ethnic German Immigration from Eastern Europe and the Former Soviet Union to Germany: The Effects of Migrant Networks.” IZA Discussion Paper 68. Bonn: Institute for the Study of Labor (November).

Dornbusch, Rudiger, and Holger Wolf. 1992. "Economic Transition in Eastern Germany.” BPEA, 1:1992, 235-61.

Eichengreen, Barry. 1990. "One Money for Europe: Lessons from the U.S. Currency Union.” Economic Policy 10: 117-87.

Eichler, Martin, and Michael Lechner. 1999. "An Evaluation of Public Employment Programmes in the East German State of Sachsen-Anhalt.” IZA Discussion Paper 94. Bonn: Institute for the Study of Labor (December).

Franz, Wolfgang, and Viktor Steiner. 2000. "Wages in the East German Transition Process: Facts and Explanations." German Economic Review 1(3): 241-69.

Funke, Michael, and Jörg Rahn. Forthcoming. "How Efficient Is the German Economy? An Exploration with Micro Data." Economics of Transition.

Giersch, Herbert, Karl-Heinz Paqué, and Holger Schmieding. 1992. The Fading Miracle: Four Decades of Market Economy in Germany. Cambridge, England: Cambridge University Press.

Görzig, Bernd, and Gerda Noack. 1999. Vergleichende Branchendaten für das verarbeitende Gewerbe in Ost und Westdeutschland: 1991-1998. Berlin: Deutsches Institut für Wirtschaftsforschung.

Grosser, Dieter. 1998. Das Wagnis der Währungs-, Wirtschafts- und Sozialunion: Politische Zwänge im Konflikt mit ökonomischen Regeln. Stuttgart: Deutsche Verlags-Anstalt.

Grundmann, Siegfried. 1998. Bevölkerungsentwicklung in Ostdeutschland: Demographische Strukturen und räumliche Wandlungsprozesse auf dem Gebiet der neuen Bundesländer. Opladen, Germany: Leske + Budrich.

Grunert, Ruth. 2000. "Bei Annäherung weiterhin Besonderheiten der Konsumstruktur in Ostdeutschland." Wirtschaft im Wandel 7: 204-09.

Hall, Robert E., and Charles I. Jones. 1996. "The Productivity of Nations.” Working Paper 5812. Cambridge, Mass.: National Bureau of Economic Research (November).

Heimpold, Gerhard. 2001. "Die Unternehmenslücke zwischen Ost und Westdeutschland - ein zentrales Problem der ostdeutschen Wirtschaft." Wirtschaft im Wandel 9: 199-205. 
Holst, Elke, Dean R. Lillard, and Thomas A. DiPrete, 2001. "Proceedings of the 2000 Fourth International Conference of German Socio-Economic Panel Study Users (GSOEP 2000). Vierteljahreshefte zur Wirtschaftsforschung 70(1): 7-14.

Hughes-Hallet, Andrew, and Yue Ma. 1993. "East Germany, West Germany, and Their Mezzogiorno Problem: A Parable for European Economic Integration." Economic Journal 103(417): 416-28.

Hunt, Jennifer. 2000. “Why Do People Still Live in East Germany?” Unpublished manuscript. Yale University (October). .2001a. "Post-Unification Wage Growth in East Germany." Review of Economics and Statistics 81(1): 190-95.

_. 2001b. "Determinants of Non-employment and Unemployment Durations in East and West Germany." Unpublished manuscript. Yale University (March).

_ Forthcoming. "The Transition in East Germany: When Is a Ten Point Fall in the Gender Wage Gap Bad News?" Journal of Labor Economics.

Institut der Deutschen Wirtschaft. 2000. Zahlen zur wirtschaftlichen Entwicklung der Bundesrepublik Deutschland. Cologne.

Jerger, Jürgen, Christian Pohnke, and Alexander Spermann. 2001. "Gut betreut in den Arbeitsmarkt? Eine mikroökonometrische Evaluation der Mannheimer Arbeitsvermittlungsagentur." IZA Discussion Paper 285. Bonn: Institute for the Study of Labor (April).

Jorgenson, Dale W., Frank M. Gollop, and Barbara M. Fraumeni. 1987. Productivity and U.S. Economic Growth. Amsterdam: North-Holland.

Katz, Lawrence F. 1998. "Wage Subsidies for the Disadvantaged.” In Generating Jobs: How to Increase Demand for Less-Skilled Workers, edited by Richard B. Freeman and Peter Gottschalk. New York: Russell Sage Foundation.

Klodt, Henning. 2000. "Industrial Policy and the East German Productivity Puzzle." German Economic Review 1(3): 315-33.

Kohaut, Susanne, and Claus Schnabel. 1999. "Tarifbindung im Wandel." $I W$ Trends 2/99: 63-80.

Krause, Peter. 1994. "Armut im Wohlstand: Betroffenheit und Folgen." Discussion Paper 88. Berlin: Deutsches Institut für Wirtschaftsforschung (February).

Krueger, Alan B., and Jörn-Steffen Pischke. 1995. "A Comparative Analysis of East and West German Labor Markets: Before and after Unification." In Differences and Changes in Wage Structures, edited by Richard B. Freeman and Lawrence F. Katz. University of Chicago Press.

_. 1998. "Observations and Conjectures on the U.S. Employment Miracle." In Third Public GAAC Symposium: Labor Markets in the USA and Germany, edited by Josef Rembser. Bonn: German-American Academic Council.

Lechner, Michael. 2000. "An Evaluation of Public-Sponsored-Continuous Vocational Training Programs in East Germany." Journal of Human Resources 35(2): 347-75. 
Ludwig, Udo, and Reiner Stäglin. 1999. "Struktureller Wandel von Produktion, Faktoreinsatz und Nachfrage in Ost- und Westdeutschland in den achtziger Jahren." In Deutsch-Deutsche Wirtschaft 1945 bis 1990, edited by Lothar Baar and Dietmar Petzina. St. Katharinen: Scripta Mercaturae Verlag.

Lundborg, Per. 1991. "Determinants of Migration in the Nordic Labor Market." Scandinavian Journal of Economics 93(3): 363-75.

Müller, Albert. 2001. "Verbesserte Produktionsmöglichkeiten bei unveränderten Absatzproblemen-Die Zeit in Ostdeutschland drängt." ifo Schnelldienst 3/2001. Munich: IFO Institute.

Mundell, Robert A. 1957. "International Trade and Factor Mobility." American Economic Review 47(3): 321-35.

Neuberger, Doris. 2000. "Regionalökonomik und Finanzierung: Kleiner und mittlerer Unternehmen: Erklärungen für ein Ost-West-Gefälle in Deutschland?" Konjunkturpolitik 46(1-2): 33-61.

Nickel, Hildegard M., Jürgen Kühl, and Sabine Schenk. 1994. Erwerbsarbeit und Beschäftigung im Umbruch. Berlin: Akademie Verlag.

Oaxaca, Ronald L. 1973. "Male-Female Wage Differentials in Urban Labor Markets."International Economic Review 14(3): 693-709.

Oaxaca, Ronald L., and Michael R. Ransom. 1994. "On Discrimination and the Decomposition of Wage Differentials." Journal of Econometrics 61(1): 5-21.

O’Connell, Paul G. J. 1997. "Migration under Uncertainty: 'Try Your Luck' or 'Wait and See.'” Journal of Regional Science 37(2): 331-47.

Pischke, Jörn-Steffen, Matthias Staat, and Stefan Vögele. 1994. "Arbeitslosigkeit, Löhne oder Weiterbildung: Warum pendeln Ostdeutsche in den Westen?" In Arbeitsmarktdynamik und Unternehmensentwicklung in Ostdeutschland, edited by Heinz König and Viktor Steiner. Baden-Baden, Germany: Nomos Verlag.

Pissarides, Christopher A., and Jonathan Wadsworth. 1989. "Unemployment and the Inter-regional Mobility of Labour.” Economic Journal 99(397): 739-55.

Prasad, Eswar. 2000. "The Unbearable Stability of the German Wage Structure: Evidence and Interpretation." Unpublished manuscript. Washington: International Monetary Fund (January).

Ragnitz, Joachim. 1999. "Warum ist die Produktivität ostdeutscher Unternehmen so gering? Erklärungsansätze und Schlussfolgerungen für den Konvergenzprozess.” Konjunkturpolitik 45(3): 165-87.

—. 2000. "Kapitalausstattung ostdeutscher Arbeitsplätze: Rückstand nicht überbewerten." Wirtschaft im Wandel 9: 254-58.

—. 2001. "Produktivitätsrückstand der ostdeutschen Wirtschaft: Eine zusammenfassende Bewertung." Wirtschaft im Wandel 7-8: 181-89.

Ragnitz, Joachim, Gerhard Müller, and Anita Wölfl. 2001. "Produktivitätsunterschiede und Konvergenz von Wirtschaftsräumen—Das Beispiel der neuen Länder." Report commissioned by the Ministry of Economics and Technology. Halle, Germany: Institut für Wirtschaftsforschung, Halle. 
Roland, Gérard. 2000. Transition and Economics: Politics, Markets, and Firms. MIT Press.

Scheuer, Markus. 1990. "Ausbildung und Qualifikation der Arbeitskräfte in der DDR.” RWI-Mitteilungen 41(697): 67-79.

Schmidt, Christoph M., and others. 2001. Perspektiven der Arbeitsmarktpolitik: Internationaler Vergleich und Empfehlungen für Deutschland. Berlin: SpringerVerlag.

Schnabel, Claus. 1999. "Tarifpolitik in Ostdeutschland zwischen gesellschaftlichen Zwängen und ökonomischer Rationalität." In Die arbeitsmarktund beschäftigungspolitische Herausforderung in Ostdeutschland, edited by Eberhard Wiedermann and others. Nürnberg, Germany: Institut für Arbeitsmarkt- und Berufsforschung der Bundesanstalt für Arbeit.

Schwarze, Joachim. 1996. "Beeinflusst das Lohngefälle zwischen Ost- und Westdeutschland das Migrationsverhalten der Ostdeutschen? Eine mikrookonometrische Untersuchung mit Daten des Sozio-ökonomischen Panels 1991 bis 1994." Allgemeines Statistisches Archiv 80: 50-68.

Seidel, Bernhard, and Dieter Vesper. 2000. “Anlagevermögen der ostdeutschen Länder und Gemeinden-noch erheblicher Nachholbedarf." DIW-Wochenbericht 24/00: 365-71.

Seitz, Helmut. 1994. "Public Capital and the Demand for Private Inputs." Journal of Public Economics 54(2): 287-307.

Siebert, Horst. 1992. Das Wagnis der Einheit: Eine Wirtschaftspolitische Therapie. Stuttgart: Deutsche Verlags-Anstalt.

Sinn, Hans-Werner. 1995. "Factor Price Distortions and Public Subsidies in East Germany." CEPR Discussion Paper 1155. London: Centre for Economic Policy Research (May).

- 2000. "EU Enlargement, Migration, and Lessons from German Unification." German Economic Review 1(3): 299-314.

Sinn, Hans-Werner, and Gerlinde Sinn. 1991. Kaltstart: Volkswirtschaftliche Aspekte der deutschen Vereinigung. Tübingen, Germany: J. C. B. Mohr. (Also published in English as Jumpstart: The Economic Unification of Germany, MIT Press, 1992.)

Sjaastad, Larry A. 1962. "The Costs and Returns of Human Migration.” Journal of Political Economy 70(5, part 2): 80-93.

Snower, Dennis. 2001. "Revenue-Sharing Subsidies as Employment Policy: Reducing the Cost of Stimulating East German Employment." In Employment Policy in Transition: The Lessons of German Integration for the Labor Market, edited by Regina T. Riphahn, Dennis J. Snower, and Klaus F. Zimmermann. New York: Springer-Verlag.

Solow, Robert M. 1957. "Technical Change and the Aggregate Production Function." Review of Economics and Statistics 39(3): 312-20. 
Strauch, Rolf, and Jürgen von Hagen. 2000. "East Germany: Transition with Unification-Experiments and Experiences." CEPR Discussion Paper 2386. London: Centre for Economic Policy Research (February).

Turner, Lowell. 1998. Fighting for Partnership: Labor and Politics in Unified Germany. Cornell University Press.

Vesper, Dieter. 2001. "Zum Infrastrukturellen Nachholbedarf in Ostdeutschland." DIW-Wochenbericht 20/01: 293-98.

Weiss, Reinhold. 1991. "Innovations- und Integrationsfaktor beruflicher Bildung: Bildungssituationen und Bildungsaufgaben in den neuen Bundesländern." In Berichte zur Bildungspolitik 1991/1992. Cologne: Institut der Deutschen Wirtschaft.

Wenzel, Siegried. 1992. "Wirtschaftsplanung in der DDR: Struktur-FunktionDefizite." Berliner Arbeitshefte und Berichte zur sozialwissenschaftlichen Forschung 75. Berlin: Zentralinstitut für sozialwissenschaftliche Forschung, Freie Universität-Berlin (October).

Young, Alwyn. 1992. "A Tale of Two Cities: Factor Accumulation and Technical Change in Hong Kong and Singapore." In NBER Macroeconomics Annual, edited by Olivier Blanchard and Stanley Fischer. MIT Press. 